\title{
Mamluk Cairo, a Crossroads for Embassies
}

Studies on Diplomacy and Diplomatics

\author{
Edited by \\ Frédéric Bauden \\ Malika Dekkiche
}

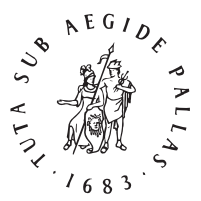

B R I L L

LEIDEN | BOSTON

For use by the Author only | (C) 2019 Koninklijke Brill NV 


\section{Contents}

Preface IX

Abbreviations XIV

Charts, Figures, and Tables XVI

Notes on Contributors $\mathrm{xx}$

1 Mamluk Diplomatics: the Present State of Research 1

Frédéric Bauden

2 Mamluk Diplomacy: the Present State of Research 105

Malika Dekkiche

\section{PART 1}

Diplomatic Conventions

3 Diplomatics, or Another Way to See the World 185 Malika Dekkiche

$4 \quad$ Strong Letters at the Mamluk Court 214

Lucian Reinfandt

5 Embassies and Ambassadors in Mamluk Cairo 238

Yehoshua Frenkel

PART 2

The Mongols and Their Successors

6 Careers in Diplomacy among Mamluks and Mongols, 658-741/126o-1341 263

Anne F. Broadbridge

7 The Golden Horde and the Mamluks: the Birth of a Diplomatic Set-Up (66o-5/1261-7) 302

Marie Favereau

For use by the Author only | (C) 2019 Koninklijke Brill NV 
8 Mamluk-Ilkhanid Diplomatic Contacts: Negotiations or Posturing? 327 Reuven Amitai

9 Baghdad between Cairo and Tabriz: Emissaries to the Mamluks as Expressions of Local Political Ambition and Ideology during the Seventh/Thirteenth and Eighth/Fourteenth Centuries 340 Hend Gilli-Elewy

10 Between Iraq and a Hard Place: Sulțān Aḥmad Jalāyir's Time as a Refugee in the Mamluk Sultanate 363

Patrick Wing

\section{PART 3}

\section{The Timurids, the Turkmens, and the Ottomans}

11 Nizāām al-Dīn Shāmīs Description of the Syrian Campaign of Tīmūr 381

Michele Bernardini

12 Diplomatic Entanglements between Tabriz, Cairo, and Herat: a Reconstructed Qara Qoyunlu Letter Datable to 818/1415 410 Frédéric Bauden

13 Fixed Rules to a Changing Game? Sultan Mehmed II's Realignment of Ottoman-Mamluk Diplomatic Conventions 484

Kristof D'hulster

\section{PART 4}

\section{The Western Islamic Lands}

14 Diplomatic Correspondence between Nasrid Granada and Mamluk Cairo: the Last Hope for al-Andalus 511 Bárbara Boloix Gallardo

15 Entre Ifrīqiya hafside et Égypte mamelouke: Des relations anciennes, continues et consolidées $\quad 5^{29}$

Mounira Chapoutot-Remadi 
16 Tracking Down the Hafsid Diplomatic Missions All the Way to the Turco-Mamluk Borders (892-6/1487-91) 566

Lotfi Ben Miled

\section{PART 5}

Arabia, India, and Africa

17 Diplomatic Networks of Rasulid Yemen in Egypt (Seventh/Thirteenth to Early Ninth/Fifteenth Centuries) $\quad 581$

Éric Vallet

18 "Aggression in the Best of Lands": Mecca in Egyptian-Indian Diplomacy in the Ninth/Fifteenth Century 604

John L. Meloy

19 Some Remarks on the Diplomatic Relations between Cairo, Delhi/Dawlatābād, and Aḥmadābād during the Eighth/Fourteenth and Ninth/Fifteenth Centuries 621

Stephan Conermann and Anna Kollatz

20 The Hați and the Sultan: Letters and Embassies from Abyssinia to the Mamluk Court 638

Julien Loiseau

21 "Peace Be upon Those Who Follow the Right Way": Diplomatic Practices between Mamluk Cairo and the Borno Sultanate at the End of the Eighth/Fourteenth Century $65^{8}$

Rémi Dewière

\section{PART 6}

\section{The Latin West}

22 The European Embassies to the Court of the Mamluk Sultans in Cairo 685

Pierre Moukarzel 
23 In the Name of the Minorities: Lisbon's Muslims as Emissaries from the King of Portugal to the Sultan of Egypt 711

Maria Filomena Lopes de Barros

24 Envoys between Lusignan Cyprus and Mamluk Egypt, 838-78/1435-73: the Accounts of Pero Tafur, George Boustronios and Ibn Taghrī Bird̄̄ 725

Nicholas Coureas

25 Negotiating the Last Mamluk-Venetian Commercial Decree (9223/1516-7): Commercial Liability from the Sixth/Twelfth to the Early Tenth/Sixteenth Century 741

Gladys Frantz-Murphy

26 Three Mamluk Letters Concerning the Florentine Trade in Egypt and Syria: a New Interpretation $\quad 782$

Alessandro Rizzo

\section{PART 7}

Material Culture

27 Écritoires: objets fonctionnels et symboliques indissociables des cérémonies officielles à l' époque mamelouke 801

Ludvik Kalus

28 Precious Objects for Eminent Guests: the Use of Chinese Ceramics in Mamluk Cairo: the Fustat Ceramic Collection from The Royal Museums of Art and History (Brussels) 823

Valentina Vezzoli

Index 843 


\title{
Mamluk Diplomatics: the Present State of Research
}

\author{
Frédéric Bauden
}

\section{1 Introduction}

Diplomatics, one of the ancillary disciplines of history, aims at "studying the textual tradition, the form and the issuing process (or genesis) of written documents." Its goals are to critically analyze documents, establish their authenticity and identify the common and peculiar elements in their texts, and to date and edit them. ${ }^{2}$ Historically, its main, if not sole, object was the study of original documents issued by (religious or secular) state chanceries in medieval Europe. In the twentieth century, diplomatics started to focus on administrative and private documents, including copies; more recently its temporal and geographic scopes have widened to the extent that they now include nonEuropean diplomatic traditions, like the Islamic or the Japanese traditions. ${ }^{3}$ While this openness certainly contributes to the renewal of diplomatics, it also means that the discipline has witnessed several developments that helped to broaden its horizon. Moreover, just as the field of diplomatic studies, i.e., those studies that concentrate on diplomacy, resumed over the last decades, leading to a reformulation of the field as 'new diplomatic history, ${ }^{4}$ several 'turns' (archival, ${ }^{5}$ performative ${ }^{6}$ ) and technological tools have impacted diplomatics in a similar way, making it even more appealing to new scholars, in spite of its deep roots in positivism. ${ }^{7}$

Over the past two centuries, diplomatics in the field of Islamic studies has seldom been addressed. It has been repeatedly argued that this disinterest was

Cárcel Ortí, Vocabulaire 21.

2 Guyotjeannin et al., Diplomatique médiévale 16.

3 As noted in the preface to this volume, the Commission Internationale de Diplomatique has recently widened its scope by including specialists of the non-European diplomatic traditions.

4 See Dekkiche's state of the research in this volume.

5 On the archival turn, see Archival knowledge cultures; Archival transformations; Blair, Introduction; Delsalle, A history; de Vivo et al., Archival transformations; Friedrich, Die Geburt; Gilliland, Afterword; Head, Spaces.

6 On the performative turn, see Moeglin, «Performative Turn ».

7 On these latest developments, see Guyotjeannin, The expansion. 
mainly due to the paucity of Islamic documentary sources before the Ottoman period, more specifically before the beginning of the eleventh/sixteenth century. However, as the last century has witnessed the identification and discovery of thousands of documents mainly written on papyrus, parchment, and paper covering larger chronological and geographical limits, the notion of a relative scarcity of documents must be moderated. As a consequence, the discipline witnessed a renewed attraction in the 196os and 1970s; some of the most active scholars in this respect include Samuel Miklos Stern (d. 1969), Lajos Fekete (d. 1969), Adolf Grohmann (d. 1977), Claude Cahen (d. 1991), Hans Robert Roemer (d. 1997), John Wansbrough (d. 2002), Victor Louis Ménage (d. 2015), Heribert Busse, Valery Stojanow, and Rudolf Veselý. These scholars seeded hopes that the works of pioneers like Antoine-Isaac Silvestre de Sacy (d. 1838) and Michele Amari (d. 1889) would not remain in vain, nor would they go unchallenged. These scholars not only contributed to an increase in the body of documents published, they also approached questions linked to diplomatics as a discipline, by drawing inspiration from the achievements of medieval European diplomatists. ${ }^{8}$ Unsurprisingly, the period witnessed the publication of several articles and books in which these scholars tackled diplomatic issues for a given period or dynasty, particularly that of the Ayyubid, ${ }^{9}$ Ottoman, ${ }^{10}$ Timurid, ${ }^{11}$ Aq Qoyunlu, ${ }^{12}$ and Safavid documents. ${ }^{13}$ Some more general conclusions about diplomatics could also be drawn. ${ }^{14}$ The generation of scholars that followed in the 199os, mostly represented by Yūsuf Rāghib and Werner Diem, continued the efforts of their predecessors, but focused their attention on unpublished documents, rather than improving the conclusions reached on diplomatic issues. In a way, they addressed the main problem posed by diplomatics; namely, that the discipline needs documents. More editions are thus required before a handbook of Arabic diplomatics can be written with

The common meaning of the word, according to the Oxford English Dictionary, is "one engaged in official diplomacy." It is used here to refer to those researching the field of diplomatics (French diplomatiste).

9 Hein, Beiträge.

10 Reychman and Zajączkowski, Handbook; Fekete, Einführung; Horniker, Ottoman-Turkish diplomatics.

11 Roemer, Staatsschreiben.

12 Keçik, Briefe und Urkunden; Busse, Untersuchungen.

13 Busse, Persische Diplomatik; Busse, Untersuchungen; Mitchell, Safavid imperial tarassul.

14 See the articles on Daftar, Diplomatics, Dīwān, Imtiyāzāt, and Inshā’ in $E I^{2}$ as well as Cahen's thoughts on the place of diplomatics in Islam in Cahen, Notes. See also the still useful bibliographic guide of Roncaglia, Essai bibliographique. 
confidence. The work of these scholars to publish previously unpublished (or unknown) documents has also included several—-mostly Mamluk—chancery manuals and formularies, which, despite their prescriptive/normative inclination, constitute valuable tools to shed light on features observed in these documents. Consequently, it is no surprise that several publications have appeared since 2000, mostly dedicated to Arabic documents, ${ }^{15}$ and, in some cases also dealing with diplomatics and diplomacy. ${ }^{16}$

Nevertheless, the documents of the Mamluk period that are tied to diplomatic relations between the sultanate and other Muslim and non-Muslim powers have been of less interest to modern scholars for the simple reason that most of these documents were published between the mid-nineteenth and the mid-twentieth century. Rather than questioning their predecessors' work, modern scholars have generally taken for granted the accuracy of the edited texts and the proposed identification of the categories to which these documents belong. This indiscriminate confidence has generated misunderstandings that have had consequences on studies dedicated to both diplomatics and diplomacy. To face these misunderstandings and correct their consequences, diplomatists must, in most cases, start from the beginning. This implies going back to the sources, i.e., the documents themselves, checking the readings and the translations, and reinterpeting their nature and their symbolic value. This process began a few years ago and will certainly yield groundbreaking results.

While the quantity of data available has increased, and in turn our knowledge of the chancery rules applied by the secretaries has benefited, it is also true that several idées reçues are difficult to counter. Scholars continue to believe misconceptions based on a Eurocentric point of view or interpretation. Words like peace treaties, capitulations, and privileges are still used to describe documents or parts of documents that were never intended to mean that for the Mamluk chancery. In such cases, reference should be made to the technical terms describing these documents in the Mamluk diplomatic tradition. In this

15 Martínez de Castilla, Documentos; Regourd, Documents et histoire; and, since 2002, the various volumes of proceedings of the Conference of the International Society for Arabic Papyrology. These publications were preceded by Stern, Documents (1965), who set the ground for similar initiatives in the future. For the Mamluk period, see the state of the arts of Bauden, Mamluk era documentary studies; Reinfandt, Mamlūk documentary studies.

16 Aigle and Bernardini, Correspondances diplomatiques; Aigle and Buresi, Les Relations diplomatiques; Aigle and Péquignot, La Correspondance; L'Autorité de l'écrit; Beihammer, Diplomatics; Favereau, Les Conventions. 
volume, several contributions engage with these diplomatic issues in a variety of ways, ${ }^{17}$ leading to what diplomatics can achieve, even in reassessing the work of the past.

This state of research, a necessary update, aims at presenting an outline of the results garnered during almost two centuries of research, and focuses exclusively on documents related to diplomatic exchanges with the Mamluk sultanate. It provides a detailed survey of the literature available on the documents preserved in archival repositories in Europe and Turkey; this should be read together with a census of these documents found in the appendix. At the same time, we emphasize the accomplishments made and the flaws identified in the works of the past. Notwithstanding, Mamluk diplomatics cannot be addressed on the sole basis of the preserved documents, not only because their number is relatively limited (thirty originals and one hundred translations), but also because their variety does not reflect the whole range of categories that were produced by the state chancery. Consequently, diplomatists have no choice but to consider other types of texts that may enhance their knowledge of the rules applied by the secretaries and broaden the corpus of documents. In a subsequent section, I have detailed in chronological order the prescriptive and normative texts, which include the chancery manuals and the formularies. I then list the descriptive works, i.e., collections of letters, which may be regarded in various respects as registers of documents. In both cases, I stress that while a large part of these texts has been published and studied, the value of others that remain in manuscript form still await assessment. On the basis of these sources, in the next section I delineate the main elements pertaining to Mamluk diplomatics, based on what can be derived from the examination of the documents identified in archival repositories and in textual sources. In so doing, my aim is not so much to detail all the rules that can be derived from the diplomatic study of these documents as it is to indicate the steps that still need to be taken in order to reach a satisfactory level of knowledge that could lead to the publication of a manual of Mamluk diplomatics.

To say that diplomatics would not exist without documents is a truism whose merit is to remind us that we need more than documents; archives are needed

17 See the contributions of Bauden, Boloix Gallardo, Chapoutot-Remadi, Dekkiche, Dewière, D'hulster, Frantz-Murphy, Reinfandt, and Rizzo. 
because diplomatists must rely on a significant number of written witnesses that also highlight the processes linked to their preservation. Archival processes are instrumental because, beyond providing answers to questions related to the practicalities of the preservation of documents, they also shed light on the reasons behind their preservation. ${ }^{18}$ Given these premises, one might argue that, in the absence of archives in Islam before the dawn of the tenth/sixteenth century, diplomatic studies are an impossibility in this field before that period. Such a position is too extreme, because, in terms of diplomatic relations, documents issued by the various Muslim chanceries are available in the archives of the recipients-almost exclusively European repositories. On the Muslim side, copies of letters received and the replies penned by the chanceries are also accessible in various kinds of sources. Several prescriptive workschancery manuals and formularies - redacted by those who were active at the state chancery have also reached us. Notwithstanding the existence of these witnesses, it is clear that the task of diplomatists working in the Islamic realm is, if not impossible, more complicated than that of their colleagues working on the European side, mainly because of what has been termed 'the silence of the archives.' ${ }^{19}$

The lack of archives before the Ottoman imperial age has puzzled scholars for decades. The debate has raged among historians of Islam who have tried, in many ways, to provide answers, putting forward various arguments that could explain the disappearance, rather than the lack, of archives in premodern Islam. ${ }^{20}$ With very few exceptions, historians have accepted the idea that, on the basis of the data given by the textual sources (prescriptive and narrative) and the documents themselves, archives did exist. ${ }^{21}$ The disappearance, whatever the processes lying behind it—loss, destruction, disposal—, is a

18 In recent years, remarkably, the debate has shifted to the latter aspect. This distinct interest in archival practices has been coined the 'archival turn'. On this, see, in particular, Delsalle, A history; Friedrich, Die Geburt; Head, Spaces; and the following special issues in journals: Archival knowledge; Archival transformations.

19 Loiseau, Le Silence des archives.

20 As Picard, De l'usage de l'écrit 128, states, it is the destruction of the archives, not their absence that is problematic. For a review of the debate and the answers, see Bauden, $\mathrm{Du}$ destin des archives. See also, since then, Bausi et al., Manuscripts and archives; El-Leithy, Living documents; Friedrich, Epilogue; Hirschler, From archive; Martinez-Gros, Mise en écriture; Müller, Der Kadi; Müller, The Ḥaram al-Šarīf collection; Paul, Archival practices; Van Berkel, Archives.

21 In addition to the references quoted in the previous note, see Rodinson, La Continuité; Bravmann, The state archives; Posner, Archives; Posner, Twelfth century “job descriptions" (where he describes the archival processes at the Fatimid chancery on the basis of a contemporary chancery manual). 
challenging issue and thus far, no definite answer has been proposed. However, in this respect, the position of historians of Islam seems to have been mainly predicated on a Eurocentrist - and at times anachronistic - view. Given that archival repositories exist on the European continent, some holding documents that date back to the eighth and ninth centuries, it is generally assumed that the same practices were applied everywhere at the same time. European diplomatists and historians explain the survival of large quantities of documents by an 'archival mindset' that prevailed in many European states from the end of the eleventh century onward. The main reasons outlined for this survival in the Middle Ages are the great significance given to written law, which went hand in hand with a larger preservation of deeds and an increase in the production of documents due to notarial activities. Additionally, the emerging powers of medieval Europe began to rely more on documents to govern while, at the same time, the spread of the use of paper favored the growth of written evidence of all kinds. These factors were concomitant with the time the documents were issued. Other factors related to the later exploitation of the documents, when these started to be used for political and ideological purposes, leading to the reorganization of the archives in the modern period. The study of documents in the late eighteenth and early nineteenth centuries for political reasons contributed to create a centripetal movement in which more documents were collected from various sources (religious and private archives, among others) and integrated with what had become national archives. The development of archives in Europe thus took place on a par with the notion of the nation-state. ${ }^{22}$

Historians of European archives also stress that the situation that prevailed across Europe was far from uniform. ${ }^{23}$ The discontinuous character of dynasties and the destructions and damnationes memoriae, all reasons that hinder the construction and preservation of archives, also existed in Europe. ${ }^{24} \mathrm{In}$ fact, the issue of lost memory ${ }^{25}$ was not peculiar to Islam. The survey of documents linked to the diplomatic exchanges between the Mamluk sultanate and other powers that have been preserved in archives shows that the European counterparts of the Mamluks did not necessarily pay particular attention to the

22 For Aragon, see McCrank, Documenting Reconquest; Péquignot, 'No hay nada.' For Italy, see Dover, Deciphering the diplomatic archives. See also Péquignot, Le Cadre des échanges, in Moeglin and Péquignot, Diplomatie; Bougard, Mise en écriture 18.

23 Bougard, Mise en écriture 17.

24 See Péquignot, Le Cadre des échanges, in Moeglin and Péquignot, Diplomatie 128 and 141. For the contemporary period, see Filippov and Sabaté, Identity and loss, especially on the destruction of archives and libraries in Sarajevo at the end of the twentieth century.

See La Mémoire perdue for the loss of the archives of ancient Rome. 
preservation of the original documents they received. For instance, the archives of the Crown of Aragon in Barcelona hold the greatest number of original Mamluk documents starting from the end of the seventh/thirteenth century; nevertheless, it is clear that archival practices were not uniform over the centuries. Catalan documents addressed to Mamluk authorities (the last one dated 1508) demonstrate that while relations with the Mamluk sultanate lasted until its downfall in 1517, the latest Mamluk document preserved in Barcelona dates from 833/1430 and the latest (in translation) dates from 842/1439. This decline in preservation not only shows that archival practices were applied unevenly; it also helps us to envision the number of documents that were lost.

Original letters have rarely survived in the European archives, ${ }^{26}$ and when they did, it is because they were related to specific cases or for political or ideological reasons. ${ }^{27}$ Our knowledge of the correspondence between the Mamluk sultans and the European powers is much better because of the copies of the translations that were recorded in the European registers. The Venetian archives, which are well-known for the richness of their collections, is a case in point: while they have only one original Mamluk letter from the end of the ninth/fifteenth century, its registers contain seventy-four translations of Mamluk documents covering the whole period of Mamluk rule. This translation and registration activity certainly helps to explain why the archivists disposed of the original Mamluk documents. The language barrier-documents in a language and a handwriting that could only be interpreted by a very few peoplealso played a role in this respect.

In the Islamic world in general, and during the Mamluk period in particular, other strategies were at play. ${ }^{28}$ Recently, several scholars have proposed various keys by which to interpret and apprehend the question of the disappearance of archives. I also emphasized that the number of documents that has survived indicates that the Mamluks were also fond of red tape. ${ }^{29}$ Tamer El-Leithy has proposed that we consider the concept of archives from a different perspective. ${ }^{30}$ More recently, Konrad Hirschler has stressed that scholars should rather focus their attention on the provincial chanceries, which were no less active

26 Péquignot, Le Cadre des échanges, in Moeglin and Péquignot, Diplomatie 139. His comment applies to diplomatic letters in European archives in general, whatever their origin. For instance, letters received from eastern rulers were kept and/or registered by the papacy as evidence of its universal relevance. See Tanase, Les Mongols.

28 See Hirschler, From archive.

29 Bauden, Mamluk era documentary studies; Bauden, Du destin des archives.

$30 \quad$ El-Leithy, Living documents. See also Vallet, Des "sultans-secrétaires?", for the Rasulid dynasty. 
than the state chancery in Cairo. ${ }^{31}$ In another contribution, I address the question of the fate of the archives of the dīwan al-insh $\bar{a}$, i.e., the state chancery where foreign letters were archived in bundles according to the month during which they were received. ${ }^{32}$ According to al-Qalqashandī (d. 821/1418), who worked for the state chancery in Cairo starting from $791 / 1389,{ }^{33}$ this archival system had already been downgraded, at least in comparison to earlier periods, when the contents of letters were recorded in registers in addition to the archiving of the originals. ${ }^{34}$ The use of registers for diplomatic letters seems to have been reinstated at the beginning of the ninth/fifteenth century, when, under the reign of al-Mu'ayyad Shaykh (r. 815-24/1412-21), Nāṣir al-Dīn Ibn al-Bārizī, the chief secretary between $815 / 1413$ and $823 / 1420$, restored the practice of copying the contents of the most significant of the incoming and outgoing letters in a register in his own hand. ${ }^{35}$ The reestablishment of an old practice such as this may also explain the presence of several collections of letters, which may have functioned as registers, for that very century. ${ }^{36}$ Moreover, it might give us a clue about the disappearance of the original letters. One letter from the Qara Qoyunlu ruler and another from the Rasulid sultan that reached Cairo during

31 Hirschler, From archive. See also the recent contributions to the debate by Paul, Archival practices, and Friedrich, Epilogue.

32 Bauden, Du destin des archives 34-5.

33 On him, see below.

34 Al-Qalqashandī explains this practice of the past in detail, with more than a hint of nostalgia for what he considered a good practice that should not have been discontinued. His argument is fair enough; we can see this same nostalgia and desire for tradition at play in the recent-unsuccessful—attempt to abolish a thousand-year-old practice of recording laws on goat and calf skin in England. See https://www.theguardian.com/politics/2016/ feb/15/lords-overruled-recording-laws-vellum-goat-calf-skin (consulted on 18 July 2017).

With regard to the registers, we know that long-standing chancery practices were still in use at the end of the eighth/fourteenth century. Al-Maqrīzì, who worked for some years at the chancery during that period, borrowed a sign that was used in registers to indicate that the original document had been issued. This sign has been attested in a fragment of a chancery register from the Fatimid period. See Bauden, Maqriziana II 111. The same sign has been identified in holographs of another scholar, one of al-Maqrīzìs friends and colleagues, Ibn Ḥajar al-'Asqalānī (d. 852/1449).

35 Al-Qalqashandī, Daw’ al-Ṣubḥ $5^{2}$ (wa-qad akhadha l-maqarr al-ashraf al-Nāṣirī șāḥib dīwān al-inshā' fī l-dawla al-mu’ayyadiyya Shaykh fỉ ḍabț muhimm al-mukātabāt al-ṣādira wa-l-wārida bi-daftar bi-khațțihi). This sentence is absent in Șubḥ al-a shā (i, 139), an indication that it was added between 814/1412, the date of the completion of Șubhal-ashā, and 821/1418, when he finished Daw' al-Șubh. See also Björkman, Beiträge 39. This example tallies with the idea that archives are more the result of initiatives taken by individuals, clerks, and those active at the chancery, than by governments. See Martinez-Gros, Mise en écriture 23; Morelle, Usages 121.

36 On these, see below. 
Ibn al-Bārizīs period found their way into the holographs of the Egyptian historian al-Maqrīī (d. 845/1442) who reused them as scrap paper. ${ }^{37}$ In the case of the Rasulid letter, Ibn Hijja (d. 837/1434), who was in charge of the redaction of deeds and letters (munshi'), recorded its text, and the answer he drafted at Ibn al-Bārizìs request, in his personal collection of documents (Qahwat alinsh $\left.\bar{a}^{3}\right){ }^{38}$ Both original letters were thus discarded because they were lent or given to al-Maqrīzì by Ibn Hijja or Ibn al-Bārizī who had already recorded a copy of them. ${ }^{39}$ The language barrier may also provide another hint about the reason for the disposal of diplomatic letters in the Mamluk period. ${ }^{40}$ When al-Qalqashandī describes letters received from Christian rulers in his magnum opus, he quotes only three examples that arrived at the chancery in 814/1411-2, i.e., the year he completed his manual, as if he could not access older letters. ${ }^{41}$

Other, definitely more tragic, events may have impacted the archives. One momentous example was reported by al-Maqrīiñ, who also worked at the state chancery in his early career. Thanks to his testimony, we know that around 7912/1389-9o, at a time of great political turmoil for the sultanate, the documents stored in a room of the state chancery were looted and sold by weight. In order to stress that these were documents and not just blank paper, he specifies that their contents were lost. ${ }^{42}$ In addition to what this report tells us about the situation that led to the disappearance of one section of the state archives (the one that held the diplomatic letters, among others), this episode enlightens us about the fate of these documents. Al-Maqrīin does not detail the categories of documents that were stolen (original letters and/or registers). Whatever the case may be, they were clearly still valuable because they could be reused. The

37 The Qara Qoyunlu letter is the topic of my article in this volume. For the reconstruction of the Rasulid letter, see Bauden, Yemeni-Egyptian diplomatic exchanges.

38 On him and his work, see below.

39 Al-Maqrīzìs interest in these letters might have arisen while he was writing his chronicle on the Mamluks, al-Sulūk, but nothing is certain. He does provide some information about the embassies, as well as news that both letters conveyed, but he refrains from giving the full text of the letters or even mentioning that he had read them.

40 This was suggested by Lammens, Correspondances diplomatiques 368 , though in polemical terms.

41 Al-Qalqashandī, Șubh al-a śā viii, 121-5.

42 See Bauden, The recovery 74. Al-Qalqashandī had started to work at the state chancery around the time this episode took place. With very few exceptions, he found the documents he quotes in his Șubh al-ashā as copies in other sources. For instance, when he mentions the truces concluded with the crusader states, he does so via (Muhammad b. alMukarram) Ibn Manzūur's Tadhkirat al-labīb wa-nuzhat al-adīb. See al-Qalqashandī, Șubḥ al-a'shā xiv, 7off. and Björkman, Beiträge 77, on this source. On al-Qalqashandī's sources in general, see Veselý, Zu den Quellen. 
original letters, if issued by the eastern chanceries, were in the shape of rolls with large interlinear spaces on the recto and no text on the verso. ${ }^{43}$ These rolls thus offered wide blank spaces. These could be cut into several pieces to combine into quires that could be reused as scrap paper by scholars like alMaqrīzì. ${ }^{44}$ The reuse of chancery and private documents has since attracted the attention of other researchers; ${ }^{45}$ we know that the practice was not specific to the Mamluk period ${ }^{46}$ or even the Islamic world. ${ }^{47}$ With regard to the registers, the usefulness of reusing them is less obvious. On the basis of a unique sample of a fragment of a register from the Fatimid period, ${ }^{48}$ we can confirm that little space was left blank on the sheets in the registers, thus, reusing them the way the scrolls were reused does not seem possible. However, I have recently established that recycled paper was produced in the Mamluk sultanate. ${ }^{49}$ In such a case, even registers full of ink could have been given new life. ${ }^{50}$

\section{Documents in Archival Repositories}

In what follows, I review the present state of research on documents related to diplomacy (as defined above), including those that are preserved in archives (originals ${ }^{51}$ and/or translations in the case of documents issued by the Mamluk chancery; and copies in registers for those issued by the other chanceries). ${ }^{52}$

43 See below.

44 In Bauden, The recovery 75, I tentatively connected the reused documents found in his notebook with the event he reported regarding the looting. I revised this interpretation in Bauden, Du destin 38. It is also worth mentioning that I have now found evidence of chancery documents being reused by another scholar, Ibn Ḥajar, a contemporary of alMaqrīzī.

45 See Hirschler, Document reuse.

46 For a Persian document dated 892/1487 that was glued on the pastedown of a Persian manuscript datable to the tenth/sixteenth century, see Afshar, Catalogue $276-7$ and figs. 10-1 (Tärīkh-i Shäh Ismā̄îl, Ms Or. Hs. 542, Vienna, Haus-, Hof- und Staatsarchiv).

47 An example of a Fatimid document is attested in the Genoese archives for the twelfth century. See the references in Bauden, Du destin 41.

48 Khan, A copy of a decree.

49 The paper produced was unusable for writing because of its color (it was probably grey from the ink). Its use was thus limited to wrapping. See Bauden, A note.

50 For other uses of documents, see Bauden, Du destin 43-4.

$5^{1}$ In diplomatic terms, the original document refers to the initial deed established, which expresses the final form and the will of the author of the deed; it is thus deemed authentic. The perfect deed either bears validation marks or was issued in such an authentic condition that it is evidently authentic. See Cárcel Ortí, Vocabulaire 30 (no. 42). In fact, we do not review copies of documents found in the sources. Though a comprehen- 
With the exception of the Ottomans, the vast majority of these documents are in European repositories, because this archival material mainly relates to European powers. This prevalence does pose some problems in terms of diplomatics for the Mamluk side, as the guidelines applied by the Mamluk chancery for non-Muslim rulers largely differed from those it followed for Muslim rulers, as we will see. I review these documents according to the classification adopted in the survey found at the end of this state of research: the various powers are organized in descending order, by the number of original Mamluk documents held. This classification is justified by the fact that originals generally have a greater value in the eyes of the diplomatist.

\subsection{Aragon}

The Archives of the Crown of Aragon (Archivo de la Corona de Aragón, ACA) in Barcelona is renowned for the quantity, the quality, and the variety of documents it has preserved from the time of the High Middle Ages. This prominence is undisputed, in terms of the documents that emanated from Muslim chanceries. Regarding the Mamluk sultanate, the ACA holds the largest number of original Mamluk documents (eleven), ${ }^{53}$ and in terms of quality and variety, the collection is far superior to the other archives in Europe. The collection is particularly notable for what appears to be the oldest original truce ( hudna) concluded between a Christian ruler, James II (r. 1285-1327), and a Mamluk sultan, al-Ashraf Khalīl (r. 689-93/129o-3). Dated 19 Ṣafar 692/29 January 1293, shortly after the sultan had conquered the last Frankish stronghold in Syria, the truce is remarkable for several reasons. It not only reproduces, almost identically, a former truce agreed upon by the predecessors of both rulers, al-Manșūr Qalāwūn (r. 678-89/1279-9o) and Alphonso III (r. 1285-91), three years earlier, ${ }^{54}$ but its text has been fully transcribed by al-Qalqashandī

sive survey of such copies would certainly be useful, it is well beyond the goals set for this state of research in terms of diplomatics. It would also require much more space than is feasible in the framework of this volume. Finally, most of these copies have already been reviewed by Malika Dekkiche in her state of research on diplomacy that follows the current state of research on diplomatics; the references she quotes there often mention these copies preserved in the sources.

53 With very few exceptions, all these documents have been described and digitized on the portal of the Spanish archives (pares.mcu.es): under "Archivo de la Corona de Aragón," then "Diversos y colleciones," and "Cartas árabes." This includes all the Arabic documents (a total of 211) exchanged by various Muslim dynasties with the Crown of Aragon, but not the fragments that recently resurfaced (see $n .58$ below).

The original of this truce is lost, but its text is known thanks to Ibn 'Abd al-Zāhir (d. 692/ 
in his opus magnum..$^{55}$ Moreover, the translation prepared by the Aragonese chancery and a copy of the letter addressed by James II to his Muslim counterpart asking for the negotiation have been kept. ${ }^{56}$ Unfortunately, the original document of the truce is poorly preserved: the text starts in what appears to be the middle of the document, the upper part of the roll is missing, and bookworms have damaged several parts of the text, particularly on the left side where the lines end. These lacunae led the editors of most of the Arabic documents preserved at the ACA to prefer the copy registered by al-Qalqashandi over the original. ${ }^{57}$ Since this publication, two fragments of this document, corresponding to the initial part and one section of the first half, have resurfaced in the ACA. ${ }^{58}$

Most of the remaining original Mamluk documents are no less significant in terms of diplomatics, as they represent an exceptional dossier of letters addressed by al-Nāṣir Muhammad (r. 693-4/1293-4, 698-708/1299-1309, 70941/1310-41) to two Aragonese kings, James II and Alphonso IV (r. 1327-36) respectively. The diplomatic correspondence, as attested by the original Mamluk letters (see fig. 1.3), which covers a period of thirty years, is the oldest preserved for the Mamluk period; it allows us to study and analyze original documents that are unique in many respects. Three lists of gifts, two appended to the end of the letters and one kept separately, also offer a rare opportunity to tackle this category of documents that is not described in the chancery manuals or in the sources. ${ }^{59}$ In addition to these original Arabic documents, the ACA collection also holds nine translations, some of which are linked to

1293), a contemporary witness who was the secretary of state and the head of the Mamluk chancery for several years. The copy was transcribed in his biography of al-Manșūr Qalāwūn, Tashrīf al-ayyām 156-64. A French translation was published by Silvestre de Sacy, Extrait. The Arabic text was first published in Amari, Biblioteca $342-52$, and translated into Italian by the same, in La guerra ${ }^{88-97}$ (no. XxxI). It was then translated into English by Holt, Early Mamluk diplomacy 132-40. See also Holt, The Mamluk sultanate.

55 Al-Qalqashandī, Șubḥ al-a šā xiv, 63-70.

56 Respectively ACA, Cancillería, Cartas reales, Jaime II, no. 222 and ACA, Cancillería, Registro 252 , fols. $38 \mathrm{a}-39$ b.

57 Alarcón y Santón and García de Linares, Los Documentos 335-8 (no. 145). Al-Qalqashandī's version was edited and translated into Italian by Amari, Trattato stipolato.

$5^{8}$ These fragments have not been digitized and are thus absent from the portal referred to above. This document, and the others linked to it mentioned above, are the topic of a paper to be read by the present writer and Marta Rubio Manso at the Fifteenth International Congress of Diplomatics (Sources for the History of "International" Relations between Political Centres in Europe and the Mediterranean (ca. 800-1600): LettersCharters-Treaties), Leipzig, 4-6 October 2018.

59 See nos. 2, 5-6 in the Survey under Aragon and Bauden, Lists of gifts. 
the former, and no fewer that seventy-one copies of documents issued by the Aragonese chancery (mostly letters and, in smaller numbers, instructions delivered to ambassadors). Despite the incredible quality of these documents, the study of the whole corpus shows that particularly in the fifteenth century, archivists were far from consistent in the attention they paid to original Mamluk documents. As stressed in the previous section, this decrease in the rate of preservation of documents from the Mamluk side shows once more that archival practices in European repositories were far from uniform.

As one might expect, such an extraordinary corpus has long drawn the attention of scholars. The Aragonese documents were first published in the eighteenth century, in the framework of the movement that saw the emergence of the exploitation of archival material for historical purposes, ${ }^{60}$ with the contribution of Antoni de Capmany de Montpalau i de Surís (1742-1813), ${ }^{61}$ then followed, in the nineteenth century, by Pròsper de Bofarull i Mascaré (17771859), who was the general archivist of the ACA. ${ }^{62}$ The vast majority of these documents were published by several scholars in the twentieth century. ${ }^{63}$ As for the original Mamluk documents, their existence was only revealed in 1903 by Julián Ribera (1858-1934) though his 'discovery' dated back to $1888 .{ }^{64}$ Ribera was responsible for the preparation of a survey of all the Arabic documents held at the ACA; this survey has remained an essential tool for archivists and all the scholars who visit the institution. Nevertheless, Ribera's publication remained largely unknown outside Spain. It is thanks to a small publication (1938) made by Aziz Suryal Atiya (1898-1988), whose interest in these texts emerged during his preparatory work for his book The Crusades in the Later Middle Ages (1938),

6o See Péquignot, La Publication. The Arabic documents are still greatly valued by the authorities of the ACA, who are fully aware of their significance for the history of diplomatic relations between the Crown of Aragon in general, and Catalonia in modern terms, and various Islamic dynasties in the Middle Ages. Evidence of this burst of interest can be appreciated from the digitization of all the documents in question as well as the display of the most noteworthy during the 2009 exhibition El Perfume de la amistad: Correspondencia diplomática árabe en archivos españoles (siglos XIII-XVII), organized at the ACA. See the exhibition catalogue $E l$ Perfume de la amistad.

61 de Capmany y de Monpalau, Antiguos tratados; de Capmany y de Monpalau, Memorias.

62 de Bofarull y Mascaré, Colección.

63 Rubió y Lluch, Diplomatari; Masiá de Ros, La Corona de Aragón; López de Meneses, Florilegio; López de Meneses, Los consulados; López de Meneses, Correspondencia; López de Meneses, Pedro el Ceremonosio.

64 Ribera, Manuscritos arábigos. Much later, González Maurazos, La documentación diplómatica, presented an incomplete survey of some of al-Nāșir Muhammad's letters and related Catalan documents. 
that the existence of the Mamluk corpus was finally unveiled to the scientific community. ${ }^{65}$ This Coptic scholar focused his attention on the corpus of letters addressed by al-Nāșir Muhammad; he made a list of these letters and provided a partial edition and a translation. While it is clear that his intention was to devote more attention to this corpus, the outbreak of World War II prevented him from doing so.

At about the same time, two major contributions appeared that derailed his future plans. In 1939, Reginaldo Ruiz Orsatti published an edition and Spanish translation of the draft of a treaty negotiated between al-Ashraf Barsbāy (r. 82541/1422-38) and Alphonso V (r. 1416-58) in 833/1430. ${ }^{66}$ A year later, two Spanish scholars, Maximiliano Agustín Alarcón y Santón (1880-1932) and Ramón García de Linares reaped the fruits of a long project first launched by Ribera at the dawn of the century (and, it would seem, completely ignored by Atiya). Delayed by the Civil War that raged in Spain, the project, which aimed to edit and translate all the Arabic documents held at the ACA, was finally published. ${ }^{67}$ The Mamluk documents included in the book were not complete. In addition to a list of gifts that was strangely left out, ${ }^{68}$ the two scholars neglected to consider a document that was labeled the "Accursed Riddle" (el damero maldito). ${ }^{69}$ The reason for this description is clear from the state of the document, which corresponds to the decree issued by al-Ashraf Barsbāy for Catalan merchants, the draft of which (mentioned above) had already been published by Ruiz Orsatti. Now, the document looks like a collection of 111 fragments of the same sizewith no loss of text-, meaning that the original roll was cut into pieces for unknown reasons. ${ }^{70}$ It is indeed a riddle, as the fragments were not numbered immediately after it was reduced to such a state. The challenge for any editor is, of course, to reconstruct the original text and put the fragments in the correct order, which is, despite the comparative material available (the draft and

65 Atiya, Egypt and Aragon. He had announced his 'discovery’ a year before: Atiya, Mamlūk Correspondence.

66 See no. 10 in the Survey under Aragon. Another edition, with some improvements, was later proposed by Makkī, Mu'āhada.

67 Alarcón y Santón and García de Linares, Los Documentos. Most of the documents were then reproduced in al-Hājjīi, al-'Alāqāt, with no improvement. See also al-Nashshār, Alāqat.

68 See no. 5 in the Survey under Aragon. Meanwhile, its text was published and translated by Atiya, Egypt and Aragon, with several mistakes.

69 See no. 11 in the Survey under Aragon.

70 Perhaps this was done to enable it to be placed on a shelf more easily than a roll? Or because some archivist planned to reuse the sheets as scrap paper? 
similar documents), no easy task. This hurdle was finally taken by Mercè Viladrich who proposed to reconstruct it with an edition and translation of the text. $^{71}$

All in all, the Aragonese corpus can rightly be considered one of the richest, with its twenty documents from the Mamluk side (eleven in Arabic and nine in translation). With the exception of the 692/1293 truce, all of these documents have been edited and translated, in some cases, more than once, leaving the impression that nothing remains to be done. Still, a close look at the available editions reveals that the editors wrongly deciphered some words, and rarely paid attention to the physical details of the documents that they were transcribing. With regard to diplomatics, a wide gamut of elements were overlooked or barely described, like the writing material, the layout, the measures, and the handwriting, to mention but a few. Such elements, significant for the accurate and comprehensive interpretation of the documents, cannot be supplied by later editors, as most of the documents were not reproduced in these publications..$^{72}$ Given this, a new edition that meets all the requirements of diplomatics is fully justified. ${ }^{73}$

\subsection{Florence}

In 1422, Florence embarked on an ambitious project to strengthen its system of trade relations and boost its commerce in the Mediterranean, and more importantly, with the Mamluk sultanate. The Medici sought to achieve this goal through improved diplomatic relations between the two powers. Though ultimately the commercial project was not as successful as expected, it contributed to regular, albeit infrequent, diplomatic exchanges. The State Archives of Florence (Archivio di Stato di Firenze, ASF) and the Laurentian Library (Biblioteca Medicea Laurenziana, BML) still preserve a collection of the tangible evidence of the diplomatic missions carried out by Florentine and Mamluk envoys. Thanks to these and other sources, it has been possible to establish that,

71 Viladrich, Jaque al-Sultán; Viladrich, Solving. The reconstruction and the edition need to be improved.

72 Ruiz Orsatti, Tratado, was the only one to provide a reproduction of the edited document, though it is of poor quality and its reduced size prohibits any improvement of the edition or analysis of its diplomatic characteristics.

73 The project The Diplomatic Exchanges between Islamic Mediterranean Powers and Christian European Cities in the Middle Ages: New Methods for the Analysis of Documents was launched by Roser Salicrú i Lluch (csic, Barcelona) with the specific aim of editing, translating, and interpreting all the Arabic and Catalan documents linked to those that are held at the ACA. The Mamluk constituent is my responsibility. 
in less than a century, between 1422 and 1510, the Florentines sent ten missions to Cairo while the Mamluks dispatched only three envoys. ${ }^{74}$

At present, nineteen Mamluk documents (ten originals and nine translations) and nine copies of documents issued by the Florentine authorities are still held in the ASF and the BML. ${ }^{75}$ The preservation of ten original Mamluk documents makes Florence the second most significant repository in terms of quantity. But the Florentine collections are also notable for another characteristic. Most of the Mamluk documents consist of letters and decrees, some of which were addressed to Florence and the remainder to Mamluk authorities. The presence of the latter in the Florentine repositories reveals that Florence specifically asked for copies of the documents that the Mamluk chancery issued and dispatched to their representatives ${ }^{76}$ (usually the governors, predominantly those in Alexandria and Damascus) for decisions taken in favor of Florentine merchants, decisions that these representatives were ordered to implement. This phenomenon was not peculiar to Florence and seems to have been practiced by the Venetians at the onset of the fourteenth century at the earliest.

The documents found at the ASF drew the attention of scholars as early as the middle of the nineteenth century. Michele Amari (1806-89), a Sicilian political émigré who spent several years in France where he studied Arabic, was the first to pore over the documents linked to Islam at the ASF. In the context of exploiting archival material to further political interests (in this case, the unification of Italy, the first capital of which was Florence), in 1863 Amari published a thick volume of about one hundred documents, including all the Arabic (originals and translations) as well as the Italian documents that he could identify in the archives. ${ }^{77}$ Four years later, Amari published a supplement of thirty-four documents, including translations from the Arabic and documents issued by the Pisan and Florentine authorities. ${ }^{78}$ These two books quickly became references for historians of trade and diplomacy between Europe and the Muslim

74 See Rizzo, Le Lys et le Lion i, 78.

75 To these, a copy of a letter in an eighteenth-century source must be added. See no. 29 in the Survey under Florence.

76 Although they were addressed to a specific (internal) authority, these were in fact multiple exemplars of the same document and as such were all original because they could not be differentiated from one another (they were in the same shape, had same kind of handwriting, and the same validation marks). Thus, it is incorrect to use the term "copy" here, though it allows us to distinguish between them.

77 The volume also includes documents related to Pisa, which came under the control of Florence from 1421, at which point its archives were incorporated.

78 Amari, Idiplomi ... Appendice. 
world, ${ }^{79}$ despite the quality of Amari's work. Unfortunately, no one took care to verify the accuracy of his editions by comparing them with the documents. The lack of reproductions in Amari's book certainly contributed to the historians' impression that they could content themselves with his work.

Though it seemed that Amari had published all the material available, other documents from the Mamluk period had yet to be unveiled, perhaps because they were in another repository. It was only in the 196os that the American scholar John Wansbrough (1928-2002), whose interest in the history of diplomatic and commercial relations between Venice and the Mamluk sultanate resulted in his PhD dissertation, became aware of the existence of two unpublished Mamluk documents kept at the Laurentian Library, where they had been transferred from the Biblioteca Imperiale Palatina in $1771 .{ }^{80}$ Wansbrough published these two documents separately and identified them as commercial treaties. ${ }^{81}$ Though he had access to more sources than Amari-particularly related to diplomatic rules like al-Qalqashandī's Șubh al-a'shā which had been published in the meantime-, his work remained far from perfect. In fact, his interpretation of these documents as commercial treaties was recently refuted. ${ }^{82}$

In the context of his $\mathrm{PhD}$ dissertation (defended in 2017) devoted to the diplomatic relations between Florence and the Mamluk sultanate, Alessandro Rizzo reviewed the whole corpus from the beginning, and offers, among other things, an edition that is respectful of the documents and pays attention to external and internal details. ${ }^{83} \mathrm{He} \mathrm{has} \mathrm{not} \mathrm{only} \mathrm{corrected} \mathrm{the} \mathrm{mistakes} \mathrm{of} \mathrm{Amari}$ and Wansbrough in the decipherment of some words, but also more correctly interpreted the true nature of the documents. In the present volume, he offers a stunning demonstration of his work on one of the documents published by Wansbrough and two others by Amari. He is able to demontrate that, contrary to Amari's interpretation, two of the documents are dated 902/1497 and not 901/1496. Moreover, he corrects Wansbrough's interpretation that one of the documents from the BML is a treaty; he shows that in fact, it is a letter addressed

79 Louis de Mas Latrie's Traités, largely based on Amari's translations, revealed the existence of the documents to a wider audience.

8o Wansbrough, Venice and Florence 485. Bernard Lewis informed him of their existence there.

81 Wansbrough, Venice and Florence; Wansbrough, A Mamlūk commercial treaty.

82 See Rizzo, Le Lys et le Lion.

83 Rizzo, Le Lys et le Lion. He is currently preparing the corpus for publication; it will appear separately from his historical study of the diplomatic relations between Florence and the Mamluk sultanate. 
to the governor of Damascus. ${ }^{84}$ These two examples confirm that the work of our predecessors should not be taken for granted and that these documents must be analyzed in light of the developments witnessed over the past decades by scholars of the 'New Diplomatics.'

\subsection{Venice}

The contacts of the Republic of Venice-the Serenissima as it is usually called - with Egypt are attested by documents from the twelfth century on. Some eighty documents covering the whole period of Mamluk rule are evidence of the intensity of their trade relations with the Mamluk sultanate. Nevertheless, only two of these documents, dating from the end of the Mamluk period, are in Arabic; the remainder are translations. ${ }^{85}$ Thus, although the collections of the State Archives (Archivio di Stato di Venezia, ASVe) are among the most remarkable in terms of the quantity of documents preserved, from the point of view of diplomatics, for the Mamluk side it is disappointing that most of these documents are in fact translations of original documents that have been discarded in one way or another. Most of these translations concern letters and decrees; the latter category is often addressed to the authorities of the sultanate in relation to Venetian merchants.

While the two original Mamluk documents have only recently attracted the attention of scholars, ${ }^{86}$ the translations, on the other hand, raised the interest of historians as early as the mid-nineteenth century. Two of these were published by the Byzantinist Gottlieb Lukas Friedrich Tafel (1787-1860), whose work was continued by Georg Martin Thomas (1817-87) with the help of Riccardo Predelli (1840-1909); Thomas and Predelli added several other documents related to diplomatic relations between Venice and the Mamluks. ${ }^{87}$ Amari also edited copies of translations of several documents obtained by the Venetians. These copies had been prepared at the request of the Florentine authorities who deemed it necessary to have full knowledge of the benefits

84 In 2016, the upper part of the two documents (one preserved at the ASF and the other at the BмL) containing the address ('unwān) were discovered in the BML. These corroborate Rizzo's interpretation of the nature of these documents.

85 There exists a third original Arabic document (now held at the Oriental Institute in Chicago), which is the subject of Gladys Frantz-Murphy's contribution to this volume. See no. 3 in the Survey under Venice. For the Mamluk documents at the ASVe in general, see Bauden, The Mamluk documents.

86 See nos. 1 and 2 in the Survey under Venice.

87 Tafel and Thomas, Urkunden; Thomas and Predelli, Diplomatarium. Several of these documents were then translated into French by de Mas Latrie, Traités. 
the Serenissima had secured for its merchants in the Mamluk territories. ${ }^{88}$ In 1953, the Egyptian scholar Tawfiq Iskandar defended his $\mathrm{PhD}$ dissertation on the commercial and political relations between Venice and the Mamluk sultanate. ${ }^{89} \mathrm{He}$ planned to publish several of the documents he had studied, but only the first volume was published. ${ }^{90}$ This document relates to Pietro Diedo's 1490 embassy to Cairo, the aim of which was to secure the smooth transition of Cyprus to Venetian control after the abdication of its last ruler, Catherine Cornaro. From 1427, Cyprus paid an annual tribute to the Mamluk sultanate, which considered the island a vassal state. This meant that Venice had to seek the sultan's approval before taking full control of this outpost that was critical for its trade in the eastern Mediterranean. The series of documents linked to the negotiation led by the Venetian ambassador was preserved at the ASVe and finally published by Franco Rossi in $1988 .{ }^{91}$ Two additional documents related to this affair can only be found in Louis de Mas Latrie's book on the history of Cyprus. ${ }^{92}$

In 1961, John Wansbrough submitted a PhD dissertation dealing with the history of commercial relations between Egypt and Venice (1442-1512);93 in subsequent years he published a number of articles of edited Arabic documents linked to this subject, but those that his dissertation contains remained largely unpublished. ${ }^{94}$ Most of these documents were later edited by Maria Pia Pedani, who devoted an article to the last agreements between the Venetian authorities and the Mamluks. ${ }^{95}$ To our knowledge, the most recent addition of this corpus was made by Benjamin Arbel, who discovered a copy of a letter addressed by the executive secretary of the sultan to the Venetian doge in $877 / 1473 .{ }^{96}$ This is further proof that although the collections of the ASVe have been examined in detail for more than one and a half centuries, they still hold delightful surprises. In addition to the unknown items that we must continue to

88 Amari, I diplomi. See nos. $28-35$ in the Survey under Venice.

89 Iskandar, Les Relations commerciales. No copy of this dissertation is known to have been preserved.

90 Iskandar, Documents inédits. See no. 47 in the Survey under Venice.

91 Rossi, Ambasciata. See nos. 42-50, 79 in the Survey under Venice.

92 de Mas Latrie, Histoire. See nos. 51-2 in the Survey under Venice.

93 Wansbrough, Documents.

94 See nos. 40, 59-60, 68, 70-3 in the Survey under Venice. No. 63 was later published by Wansbrough, see A Mamluk ambassador.

95 Pedani, Gli ultimi accordi. With the exception of nos. 71-3 (and no. 63 already published by Wansbrough), all the documents mentioned in the previous note are included in Pedani's edition.

96 Arbel, Levantine power struggles. See no. 41 in the Survey under Venice. 
search for, other documents also remain unpublished so far. These include two translations from 821/1418: one made in the Venetian consulate in Alexandria of a decree addressed by the Cairene chancery to the governor of Alexandria and the second, a safe-conduct issued for the Venetians. ${ }^{97}$ Another document, this one issued by the Mamluk chancery and thus a unique original piece held by ASVe, is in process of publication. It deals with the tribute that Venice agreed to continue to pay to the Mamluk authorities in exchange for its takeover of Cyprus. ${ }^{98}$

In this volume, Gladys Frantz-Murphy tackles one of the latest additions to the corpus of Mamluk documents on Venice. The document is now preserved in the Oriental Institute in Chicago. Its previous owner, Bernhard Moritz (1859-1939), had been the director of the Khedival Library in Cairo and managed to acquire a collection of manuscripts and documents that he sold to the Oriental Institute in 1929. Moritz published the document in 1915 and identified it as the first firmann issued by the Ottomans for the Venetians at the time of the conquest of Egypt. ${ }^{99}$ This attribution was indiscriminately accepted until Frantz-Murphy re-examined the text in a new light and concluded that the document was actually a draft of a text likely prepared by the Venetians to be issued by the last Mamluk sultan who had already fled Cairo. ${ }^{100}$

In addition to the copies preserved in various registers at the ASVe, another Venetian source provides a few more documents that need to be addressed here: Marino Sanuto's (1466-1536) diaries. Sanuto played a major political role in the administration of the Venetian Republic, as he served in its senate from 1498 to 1516 . During these and subsequent years, he kept a diary that truly constitutes a universal history of the close ties between the Serenissima and the various powers in Europe and beyond, along with the news that reached Venice steadily, day by day. Moreover, his diary covers the last years and the downfall of Mamluk rule and constitutes a unique witness of the exchanges that took place during this period between Venice and the sultanate; it includes numerous copies of official documents, among them translations of Mamluk letters and decrees that were not recorded in the Venetian archives. This mine of information only became available at the end of the nineteenth century. ${ }^{101} \mathrm{~A}$ later

97 See nos. 24-5 in the Survey under Venice.

98 See no. 2 in the Survey under Venice.

99 Moritz, Ein Firman. The document was then translated by Hartmann, Das Privileg. See no. 3 in the Survey under Venice.

100 See her contribution in this volume.

101 Sanuto, Diarii was published in fifty-eight volumes between 1879 and 1903. It contains sev- 
Venetian historian, Carlo Antonio Marin (1745-1815) also transmitted the text of a decree on the basis of the copy registered in the ASVe. ${ }^{102}$

\subsection{Ragusa}

The Republic of Ragusa (now Dubrovnik) engaged in diplomatic relations with the Mamluk sultanate shortly before its end, although Dalmatian merchants had been active in its territories for centuries. ${ }^{103}$ Consequently, the Dubrovnik State Archives (Državni Arhiv u Dubrovniku, DAD) does not hold a huge number of Mamluk documents related to diplomatic contacts. Only three have been identified and they confirm that the Ragusan Republic only entered into negotiations over trade in the tenth/sixteenth century. Along with a letter addressed by the govenor of Alexandria to the ruler of Ragusa in 916/1510, the DAD also contains a letter of Qānșawh al-Ghawrī (r. 9o6-22/1501-16) and a decree by the same, dated 921/1515. In addition to the confirmation of various clauses aimed at protecting the Dalmatian merchants, both the letter and the decree are related to the request from Ragusa to be allowed to establish a consulate in Alexandria. At that precarious period for the Mamluks, the sultan, eager to encourage trade, granted the consulate without complications. The three documents are known thanks to the edition and the Croatian translation provided by a local scholar, Besim Korkut. ${ }^{104}$ His work, which includes facsimiles of the documents, was recently translated into Arabic to reach a wider audience. ${ }^{105}$ The value of the collections of the DAD await evaluation to establish whether or not translations of Mamluk documents and copies of Ragusan documents sent to Cairo are still available in the registers.

\subsection{Ottomans}

As noted in the following section, contacts between the Ottomans and the Mamluks, which we know began in the mid-eighth/fourteenth century ${ }^{106}$ and intensified during the ninth/fifteenth century until the Ottomans vanquished the Mamluks, are documented in several collections of documents. Thus, given

enteen documents of interest for our purpose. See nos. $53-8,61-2,64-6,69,74-7$, and 8 o in the Survey under Venice.

102 Marin, Storia. The text of the document was translated into French by Reinaud, Traités. The copy of the document preserved in the ASVe was finally edited by Wansbrough, Documents. See no. 67 in the Survey under Venice.

103 As witnessed by the private documents published in Krekić, Dubrovnik (Raguse) et le Levant.

104 Korkut, Arapski dokumenti.

105 Qurqūt, al-Wathā'iq al-'arabiyya.

106 On this early period, see Björkman, Die frühesten türkisch-ägyptischen Beziehungen. 
that the Ottoman archives are praised for their abundance and considered comparable to their European counterparts, researchers would expect to find if not hundreds, at least dozens of documents related to the diplomatic exchanges between the two powers. While there is no doubt that further research in the Başbakanlık Arşivi in Istanbul would yield additional items, thus far we know of only four documents, all of which are from the end of Mamluk rule (early tenth/sixteenth century). These are two original letters, one issued by the governor of Aleppo and the other by Qānșawh al-Ghawrî, ${ }^{107}$ one translated letter of the same was registered in the Ottoman archives and, finally, a copy of a letter addressed by Mehmed (r. 848-50/1444-6, 855-86/1451-81) to al-Ashraf Qāytbāy (r. 872-901/1468-96). The material preserved in the Ottoman archives, despite its paucity, is nonetheless of interest because it shows that, at the beginning of the tenth/sixteenth century, the Mamluk chancery was able to issue letters in Ottoman Turkish. ${ }^{108}$

\subsection{France}

From the seventh/thirteenth century, a significant presence of merchants from various ports of Provence and Languedoc, particularly from Marseilles, is documented in Alexandria. Though Provence was not integrated into the kingdom of France before 1481, Marseilles became so congested by French merchants heading south to the Mediterranean that the consul of Marseilles started to represent them in Alexandria. It was only in 1447 that Charles VII (r. 142261) dispatched an emissary to Cairo with the expectation that al-Zāhir Jaqmaq (r. 842-57/1438-53) would grant the French merchants the same commercial advantages the Venetians enjoyed in the Mamluk territories. This was the beginning of more frequent contacts between the two powers that extended until the end of Mamluk rule. ${ }^{109}$

Despite these contacts, no original Mamluk documents have been preserved in the French Archives. ${ }^{110}$ The only document that we can refer to in this context is in fact an Ottoman decree issued in 935/1528 by Sulaymān the Magnificent (r. 926-74/1520-66) in favor of the Catalan and French merchants trading in Egypt. This decree mostly reproduces the contents of a previous decree

\footnotetext{
107 Published by Edhem, Misır Fethi; Kerslake, The correspondence. See also Yüksel Muslu, The Ottomans 33 o n. 33 .

108 Provided that this is the original letter and not an Ottoman copy; the letter was published in Edhem, Misir Fethi.

109 For a brief overview of these contacts, see Tuchscherer and Pedani, Alexandrie ottomane $115^{-21 .}$

110 The outdated study of Charrière, Négociations, starts with the reign of Francis I (r. 151547), and only refers to Ottoman documents.
} 
issued by Qānșawh al-Ghawrī in 913/1507 with the same purpose. In 2011 this document was identified in the holdings of the Departmental Archives of the Yonne (Auxerre) and subsequently published.111

In addition to this exception, we have translations of some Mamluk letters and letters addressed by the French king to the Mamluk sultan (transcribed in registers and sources) that cover the second half of the ninth/fifteenth century. Charles vir's embassy was received positively in Cairo in 1447 and his emissary brought back a letter from Jaqmaq (r. 842-57/1438-53) that was translated. The only trace left of this letter can be found in a contemporary source, Mathieu d'Escouchy's (ca. 1420-83) Chronicle covering the years from 1444 to 1467 . An excerpt from the French translation of another letter addressed by Qānșawh al-Ghawrī to Louis XII (r. 1498-1515) in 916/1510 was also located in another contemporary source, Jean Le Maire de Belges' (1473-1524) political pamphlet against the pope entitled Le Traictié. ${ }^{12}$ In addition to these two letters on the Mamluk side, three letters ${ }^{113}$ sent by French kings have been preserved in registers and are now available at the Bibliothèque nationale de France (MSs Français 2893 and $\left.5909^{114}\right)$. These have barely been studied. ${ }^{115}$

\subsection{Cyprus}

Under the house of Lusignan, the relations between Cyprus and the Mamluk sultanate may be characterized as mainly confrontational. As the last outpost of Frankish rule in the eastern Mediterranean, the island remained a point of departure for military expeditions and pirate raids led against Mamluk harbors on the Syrian and Egyptian coasts. With the Mamluk conquest of the island in 1427, the Lusignan kings recognized the sultan's authority and agreed to pay an annual tribute. This new status impacted the way the Mamluk chancery addressed the Cypriot king, who had become a vassal of the sultan. Notwithstanding these exchanges, which the sources sometimes relate in great detail, no original document for the Mamluk side has been preserved. The translation of two letters addressed by the sultan to the ruler of Cyprus have nonetheless been recorded in local sources and were published by Louis de Mas Latrie in his history of the island under the Lusignan. ${ }^{116}$ Moreover, a copy of instructions

\footnotetext{
111 Tuchscherer and Pedani, Alexandrie ottomane 1. See no. 1 in the Survey under France.

112 See no. 3 in the Survey under France.

113 See nos. 4-6 in the Survey under France.

114 Another copy of this collection of documents is held in Troyes. See Macler, Une lettre royale.

115 Alessandro Rizzo is currently working on the documents mentioned in this section.

116 See nos. 1-2 in the Survey under Cyprus. The first letter was identified in George Bous-
} 
delivered by the king to the ambassadors who had to negotiate a truce on his behalf with the sultan are registered in the Venetian Archives and were also published by de Mas Latrie. Additional documents related to Cyprus after it came under Venetian rule have been reviewed above.

\subsection{Hospitallers of Rhodes}

The Order of St. John of Jerusalem, which first settled in Rhodes after the fall of Acre in 1291, was forced to leave the island after the Ottomans occupied it in 1522. This led to the installation of the Order in Malta, where its archives have been integrated into the collections of the National Library. It is there that de Mas Latrie found a letter related to Cyprus; it is dated 1448 and addressed by the Grand Master to Jaqmaq. ${ }^{117}$ Another document containing a proposal for a treaty was sent to al-Nāșir Faraj (r. 801-8/1399-1405, 808-15/1405-12) in 1403; this document was located by Sebastiano Paoli (1684-1751) and published in a collection of documents on the Order. ${ }^{118}$

\subsection{Genoa}

Like the Venetians and the Pisans, the Genoan merchants were among the first of those on the Italian peninsula to engage in commercial relations with Egypt. Thus, we would expect to find documents related to their diplomatic contacts with the Mamluk sultanate. Yet, the State Archives of Genoa (Archivio di Stato di Genova, ASG) holds only one document in translation. It is a truce concluded in 129 o by the authorities of Genoa with al-Manșūr Qalāwūn (r. 67889/1279-90). The Arabic version was preserved in a contemporary source ${ }^{119}$ and can be checked against its translation. This text of this truce drew the attention of scholars as early as Silvestre de Sacy $\left(175^{-1838)}\right.$, who published both versions of the text in 1827 . This publication was followed by other translations in Italian and English and a new edition of the Arabic and Latin versions. ${ }^{120}$

\subsection{Naples}

The destruction of a major part of the collections of the State Archives of Naples (Archivio di Stato di Napoli, ASN) during the World War II, which saw

tronios' chronicle (on which see Coureas's article in this volume) and the second in an anonymous chronicle held in the BnF (Paris).

117 See no. 2 in the Survey under Hospitallers of Rhodes.

118 See no. 1 in the Survey under Hospitallers of Rhodes.

119 Ibn 'Abd al-Z̄āhir's Tashrîf al-ayyām.

120 See no. 1 in the Survey under Genoa. 
the complete annihilation of the Anjou and Aragonese chancery registers that covered the years from 1265 to 1505 , leaves no hope of discovering documents on the limited relations between Naples and the sultanate. Yet, in another repository, namely the Archives of the Custody of the Holy Land in Jerusalem, a rare document bearing witness to the exchanges between Queen Joanna I $(r$. 1344-82) and al-Ashraf Sha'bān (r. 764-78/1363-77) was preserved. This document was published by Girolamo Golubovich $\left(1865^{-1941)}\right.$ in his history of the institution, which he based on documents preserved in the archives of the Custody. ${ }^{121}$

\subsection{Pisa}

Like Venice and Genoa, Pisa was eager to secure agreements with the Mamluk sultanate with provisions like those that had been granted to them by the predecessors of the Mamluks, the Ayyubids. Mohamed Ouerfelli devoted a study to the treaties concluded by Pisa with Egypt. ${ }^{122}$ Nevertheless, for the Mamluk period, the State Archives of Pisa (Archivio di Stato di Pisa, ASPi) hold only a copy of credentials given to the Pisan ambassador sent to al-Ẓāhir Barqūq in 1385 . This document was published by Michele Amari in his pioneering work on the archival material related to diplomatic relations with Muslim powers. ${ }^{123}$

\subsection{Savoy}

Charles I, duke of Savoy (r. 1482-90), was the titular king of Cyprus, because Queen Charlotte of Cyprus (r. 1458-63) was married to Charles's paternal uncle, Louis. Charlotte, however, was exiled by her illegitimate half-brother James II (r. 1463-73), who was recognized as king by the Mamluks. In 1485, Charlotte surrendered her right to the crown to Charles. Aware that his claim to the kingdom of Cyprus could not succeed without the approval of the Mamluks, who regarded the island as a vassal state, Charles entered into negotiations with Cairo. A unique witness of this first contact has been preserved in the State Archives of Turin (Archivio di Stato di Torino, ASTo): it consists of a copy of Charles I's letter to al-Ashraf Qāytbāy, dispatched to Cairo in $1488 .{ }^{124}$

\footnotetext{
121 The original document on parchment is in Jerusalem, and a copy is kept in Rome. See no. 1 in the Survey under Naples.

122 Ouerfelli, Les Traités.

123 See no. 1 in the Survey under Pisa.

124 The document is unpublished. See no. 1 in the Survey under Savoy.
} 
This assessment of documents held, for the most part, in archival repositories shows that the corpus is imbalanced, at least when compared to the quantity of material available to the European diplomatic tradition. With just thirty original Mamluk documents, most of which are preserved in Barcelona and Florence, scholars who wish to focus on diplomatic elements are left with a comparatively small number of documents. In terms of the variety of the categories of documents, while their typology is greater than expected (letters, decrees, safe-conducts, lists of gifts), other categories (like truces) remain either poorly represented, or are completely missing (like the instructions delivered to Mamluk envoys). Of course, the number of translated Mamluk documents is far greater (one hundred) and these offer an opportunity to enlarge the corpus, although, in terms of diplomatics, translations invalidate several layers of interpretative elements (e.g., layout, marks of validation). As for documents issued by the other chanceries, mostly copies in registers as we would expect, the number is rather disappointing (ninety-five), though further research in the archives could yield copies so far unidentified. Finally, the bulk of all these documents that are preserved in European archives concern non-Muslim powers, a factor that further distorts our knowledge of Mamluk diplomatic practices, for the simple reason that the Mamluk chancery applied a different set of rules when issuing documents addressed to non-Muslim rulers. If our appreciation of these rules is rather satisfying for this category of rulers, our knowledge is limited to the most commonly represented category, that is, letters.

Original documents represent the majority of diplomatics. The paucity of original documents for Islam in general, and for the Mamluk period in particular, has induced scholars to consider normative and narrative sources that are sometimes regarded (typically by historians) as equivalent to original documents. We must recognize that studies based on chancery manuals and formularies can lead to stimulating results, if we bear in mind that their function was mainly prescriptive and normative and usually both, rather than descriptive. Copies of letters quoted in such sources may be presented as examples from which the historical elements that would permit our identification of the recipient and/or the issuer have been replaced-most of the time with the all-purpose name fulān (so-and-so). By contrast, collections of letters that offer models of epistolography normally retain most of the historical information contained in the texts they reproduce. In some cases, copies can even 
be regarded as copies figurées, i.e., copies in which the transcriber tries to faithfully reproduce some elements of the original. ${ }^{125}$ For instance, such elements may correspond to the motto or the signature of the ruler ('aläma): its shape and its position on the document can be rendered in a way that implies that the author saw the original. In other cases, the transcriber may indicate the color of the ink in specific parts of the text, the format of paper, or the presence of an impression left by a seal. ${ }^{126}$ Consequently, these works cannot be ignored by the diplomatist who wishes to collect data on diplomatic rules with the aim of comparing them to original documents. At the same time, both diplomatists and historians should be aware that the data offered by these categories of sources, particularly the narrative sources, can be problematic — in some cases they may even be false $\mathrm{s}^{127}$ - and the copies of the documents they transmitted must be rigorously critiqued with the tools available. ${ }^{128}$

125 For the copie figurée, see Cárcel Ortí, Vocabulaire 33 (no. 56).

126 See Bauden, Les Relations diplomatiques 6 and 9-10.

127 For instance, Ottomanists maintain that the letters quoted by Ferīdūn Bey in his collection were fabricated for the early Ottoman rulers up to Murād II (r. 824-41/1421-44). See Yüksel Muslu, The Ottomans 33. On the reliability of copies of documents in narrative sources, see Brinner, Some Ayyūbid and Mamlūk documents.

128 For the reasons invoked above, copies of documents found in narrative sources are not detailed in what follows: in diplomatic terms, such witnesses can rarely be taken into account, although in some cases, these sources were authored by those who directed the chancery. It appears that in such cases the copies quoted may have been drafts of documents that were never issued. Among the Mamluk historians who were keen to quote copies of documents we can mention Ibn 'Abd al-Ẓāhir (d. 692/1293), Baybars al-Manșūīi (d. 725/1325), Shāfi b. 'Alī (d. 730/1330), al-Nuwayrī (733/1333), Ibn al-Dawādārī (d. after 736/1336), Ibn al-Furāt (d. 807/1405), al-Maqrīzì (d. 845/1442), and al-'Aynī (d. 855/1451). A majority of these documents dealing with the crusader states have been studied by various scholars, the most important of whom are Silvestre de Sacy, Lettre; Langlois, Le Trésor; Gabrieli, Trattato; Holt, Early Mamluk diplomacy; Holt, The treaties; Holt, Treaties; Amitai-Preiss, An exchange of letters; and Troadec, Une lettre. Narrative sources composed by historians from other regions of the Islamic world should also be taken into account, like the Moroccan al-Maqqarī (d. 1041/1632), who settled in Cairo at the end of his life. For a document related to the Merinids and the Mamluks found in his Nafh al$t \bar{t} b$, see Canard, Les Relations. We must also take into consideration sources composed by Christian powers, like the Byzantines. For a Greek translation of a letter addressed by al-Nāșir Ḥasan (r. 748-52/1347-51; 755-62/1354-61) to the Byzantine emperor John vI Kantakouzenos (r. 1347-54) in 1349 and recorded in the latter's History, see Canard, Une lettre. 


\subsection{Chancery Manuals and Formularies}

Like the ars dictaminis and its corollary, the ars dictandi, of medieval Europe, ${ }^{129}$ insh $\vec{a}$, the art of writing, in particular writing diplomatic letters-hence the name of the Mamluk chancery (dīwän al-insh $\bar{a}$ ) —was subject to a theoretical framework of guidelines for the art of epistolography. ${ }^{130}$ Mostly prescriptive and normative, the vademecums composed by the main actors, i.e., the secretaries, were relatively popular among their peers, but did not draw much interest beyond the chancery clerks. While some of these manuals have been preserved, the number of copies that have reached us is rather limited in comparison with other categories of books. ${ }^{131}$ The authors conceived their works as handbooks that generally detailed the precepts for chancery scribes and provided various models of letters. For this reason, they usually referred to their works as dustūr (or dastūr), a word of Persian origin that was used to define the register in the Abbasid period. ${ }^{132}$ Given the information overload and the subsequent development of Mamluk encyclopedias, ${ }^{133}$ some authors tried to address the issue of knowledge by embracing the genre and composing works to offer users and readers all the necessary elements that secretaries required.

With its fourteen volumes in print, al-Qalqashandī's Subh al-ashā is a case in point. Nevertheless, the result of its publication was counterproductive for modern scholars: given its size and comprehensiveness, it was considered an indispensable, if not unique, source for the study of documents produced in Egypt and Syria from the Fatimid to the Mamluk period; thus, for a long period,

129 The ars dictandi refers to general, mostly theoretical treaties on the rules of composition for diplomatic letters. See Camarigo, Ars dictaminis; Grévin, Rhétorique 130-2.

130 In general, see Roemer, Inshā'; for the Mamluk period, see al-Musawi, Pre-modern belletristic prose. For a review of the genre and the works that are available, see Veselý, Zur arabischen Kanzleiliteratur; Veselý, Die inšā'-Literatur.

131 Some scholars have even questioned whether these manuals were popular among secretaries (see Van Berkel, al-Qalqashandī 338). We can establish that al-Qalqashandī's huge work, Șubh al-ashā, was copied twice by his son, in both cases for those in charge of the state chancery. See Bauden, Like father 195, n. 70. The size of the work, though, seems to have thwarted the author's efforts, as he was invited to produce a summary (Daw' al-Subh al-musfir), also at the request of the head of the state chancery. See Bauden, Maqriziana XIII 214.

132 See al-Zabīìi, Tāj al-'arūs xi, 292-3. Ibn Faḍl Allāh describes his al-Ta'rīf as such (al-Ta'rî̃f 4: aḍac lahu dustūr) and Ibn Nāzir al-Jaysh does the same for his al-Tathqüf (al-Tathqîf 87: al-qism al-thānī min al-dustūr al-mubārak). See also al-Qalqashandī, Șubḥ al-a'shā ix, 320, where he refers to Ibn Nāzir al-Jaysh's text as a dustūr. He also mentions other examples for the two Ibn Faḍl Allāh brothers, Aḥmad and 'Alī. See Björkman, Beiträge 75 .

133 On the develoment of encyclopedias in the Mamluk period, see Muhanna, Why was the fourteenth century; Van Berkel, Opening up a world of knowledge. 
other manuals were thought to be unnecessary. This long-standing impression was only overcome forty years ago with a movement to publish the major works of the Mamluk period, a movement launched and led, for the most part, by Rudolf Veselý. The chancery manuals and formularies composed during the Mamluk period, which have been published or still await publication, are reviewed in the following pages, according to chronological order, as the context of their writing must be kept in mind for any documentary analysis to be meaningful. Rules, and the subsequent models, were valid at the time these authors were active. Thus, their works should only be considered relevant for their period of activity.

Shihāb al-Dīn Aḥmad Ibn Faḍl Allāh al-'Umarī (d. 749/1349) belonged to a family whose members were at the forefront of secretaryship throughout the eighth/fourteenth century. Of Syrian origin, he became the deputy of his father, Yahyā (d. 738/1337), when the latter was called to Cairo to head the state chancery in 729/1329. He served in this capacity until his father's death, at which time he fell from favor and returned to Damascus where he died. He dedicated his idle time to the composition of his major works, including al-Ta'rif bi-l-muștalah al-sharîf, the redaction of which can be dated between 744/1343 and $746 / 1345$. Presented as a handbook, its aim was to gather the guidelines that were to be applied for the redaction of various categories of documents issued by the chancery, and offer samples of the recurrent elements (address, invocatio, etc.). First published in Cairo in 1896 , it took one century before the first critical edition was eventually published by the Jordanian scholar Samīr alDurūbī. ${ }^{134}$ Ibn Faḍl Allāh al-'Umarī also wrote two small treatises that he dedicated to the category of administrative correspondence, a subject he did not address in al-Ta'rīf. ${ }^{135}$ Ibn Faḍl Allāh al-'Umarì's brother, 'Alī, who succeeded

134 Ibn Faḍl Allāh al-'Umarī, al-Tárî̄f. See also his study published at the same time: al-Droubi, A critical edition.

135 Rudolf Veselý published both of them: Veselý, Zwei Opera Cancellaria Minora. Veselý edited two copies of the first treatise, entitled 'Urf al-ta'rîf, from ms Arabic 3849 (Dublin, Chester Beatty Library) and Ms Arabe 926, fols. 94-108 (Paris, BnF). 'Urfal-ta'rïf was more recently edited by al-Durūbī: Ibn Faḍl Allāh al-'Umarī, 'Urf al-ta'rīf. Veselý also found the second treatise in the Paris MS (fols. 108-14), but it was in a truncated form and had no title. It appears that the full text can be found in an early copy dated 827/1424 preserved in Leipzig (Ms Vollers 493, Leipzig, Universitätsbibliothek), where it is entitled al-Nubdha al-kāfiya fìma'rifat aw $\bar{a}^{c}$ al-kitāba (a later owner added the word wa-l-qiyāfa at the end of the title). This fuller version, based on the Leipzig copy, was published recently: Ibn Faḍl Allāh al-'Umarī, al-Nubdha al-kāfiya. Another text attributed to Ibn Faḍl Allāh al-'Umarī, al-Tarassul fí qawāid al-mukātabāt (MS 2479, fols. 42-58, Istanbul, Topkapı Sarayı Müzesi Kütüphanesi), awaits investigation to establish whether it is an original text or just another copy of one of the texts mentioned above. 
his father as head of the state chancery, also penned a handbook (dustür) that is only known thanks to al-Qalqashandi's quotations from it. ${ }^{136}$

One generation later, Taqī l-Dīn 'Abd al-Raḥmān b. Muḥammad al-Taymī, better known as Ibn Nāẓir al-Jaysh (d. 786/1384), enlarged the corpus of handbooks on secretaryship. Like his predecessor, Ibn Nāzir al-Jaysh was of Syrian origin, but born in Cairo. He was the son of a superintendent of the army bureau (näziral-jaysh), a chancery department. He started his career as secretary at the state chancery in $748 / 1347-8$, a position that he held for thirty years, until his father's death (d. 778/1377). That year, he inherited his father's position, which he filled until his tragic death. ${ }^{137}$ He redacted his handbook, entitled Tathqif al-ta'rïf bi-l-muștalah al-sharïf, after he left his position as secretary (i.e., after 778/1377) and presented it as a contribution to his son's career at the chancery. In contrast to what the title might suggest, his handbook was not conceived as a supplement to $a l-T a r i \bar{f}$, but as an original work in its own right, one that covered the evolution of diplomatic protocol for documents from the beginning of eighth/fourteenth century to the moment he was writing. The author often refers to the situation that prevailed in Ibn Faḍl Allāh al-'Umarì's time and his own, though he emphasizes the changes that the chancery underwent in the meantime. The handbook remained almost unnoticed until Rudolf Veselý published a critical edition based on five manuscripts. ${ }^{138}$

It took another generation before the next contributor to our knowledge of chancery practices wrote his manual. Aḥmad b. 'Abdallāh al-Qalqashandī (d. 821/1418) ${ }^{139}$ was born in a small village of the Delta, from which his family name is derived. He moved to Alexandria, where he was educated and obtained his first job in the service of the governor, and later settled in Cairo. In the capital, his expertise secured his place in the state chancery, where, in 791/1389, he started a career as a lower-level secretary (kātib al-darj). Later, he left his

136 Björkman, Beiträge 75 .

137 He overstepped his duty; the sultan then hit him with his pencase and ordered that he be bastinadoed. He died of his wounds a few days later. See Ibn Nāẓir al-Jaysh, Tathqüf al-ta'rīf $\mathrm{x}$.

138 Ibn Nāzirir al-Jaysh, Tathqīf al-ta' rîf. It is worth mentioning that Ms Arabe 4437 (BnF, Paris), catalogued by de Slane, Catalogue 707 as Ijābat al-sāil ilā márifat al-rasāil (and followed by Brockelmann, Geschichte, Sup. ii, 55), is another copy of Ibn Nāzir al-Jaysh's Tathqüf alta'rîf. The first folio belongs to another text correctly entitled Ijäbat al-sā'il and apparently deals with the ikhwāniyyāt, but from fol. 2a onwards, the text is that of Tathqïf al-ta'riff.

139 On him, see Van Berkel, al-Qalqashandī; 'Izz al-Dīn, Abū l-Abbās al-Qalqashandī. The name of al-Qalqashandī's father appears in modern reference works as 'Alī, based on the information provided in the biography al-Sakhāwī (902/1497) dedicated to al-Qalqashandī. It has recently been established that this historian was wrong. See Bauden, Maqriziana XIII 213-4. 
position to work as a deputy judge in an office of professional notaries. ${ }^{140}$ His second major work, and magnum opus, Șubh al-a'shä fi kitābat al-inshä’ was composed after he had left the chancery; he mentioned that he completed its redaction in 814/1412, six years before his demise. ${ }^{141}$ Considered a manual, Subh al-a shā was in fact conceived as an encyclopedia covering all the fields about which the perfect secretary should be aware and have knowledge: history, geography, rhetoric, calligraphy, etc. The author also wrote his prescriptive manual in the long tradition of document production that included using documents dating from the Prophet's period. Thus, we should not be surprised that the printed work is fourteen volumes and approximately 6,500 pages. The value of the work was appreciated during al-Qalqashandì's last years, and for the following decades, by the main figures at the chancery. ${ }^{142}$ The book also drew the attention of modern scholars, even before it was published. ${ }^{143}$ It was only between 1913 and 1919 that the whole work was edited under the direction of an Egyptian scholar, Muḥammad 'Abd al-Raḥmān Ibrāhīm, and based on all the copies identified at that time. ${ }^{144}$ Despite some flaws, which are inevitable for such a huge work, the edition is regarded as of high quality; it even notes details reproduced by the copyist, like the place of the sultan's motto or signature, or the shape of the letters in the section on calligraphy. 145

The text is also famous for its multilayered structure, with chapters, subchapters, sections, subsections, and so on, which makes consulting it almost

140 See Bauden, Maqriziana XIII 212, where these details are provided from the biography of a contemporary and companion (al-Maqrīzī).

141 For the chronology of his works, see Bauden, Maqriziana XIII 216.

142 The work was copied twice by his son, in both cases it was commissioned by someone who directed the state chancery, as noted in n. 131 above.

143 To my knowledge, the first scholar to become interested in the work was the Belgian Henri Lammens (1862-1937). He published two articles, in which he translated the sections devoted to Mamluk correspondence with Christian rulers: Lammens, Relations officielles; Lammens, Correspondances diplomatiques.

144 Al-Qalqashandī, Șubh al-aśsha. A reprint appeared in 1963 in Cairo and has since been reproduced several times with only the date changed. One handwritten volume has remained unnoticed since then: Ms 1897, Algiers, Bibliothèque nationale. See Fagnan, Catalogue 543. On the title page, the copyist has entitled the work al-Durr al-manzūm but it tallies exactly with the first volumes of Șubh al-ashāa. Fagnan dates it to the beginning of the ninth/fifteenth century, i.e., almost contemporaneous with the author's death. Unfortunately, the text is lacunar and has been so badly damaged by bookworms that it is very fragile and difficult to manipulate.

145 These elements were not typeset, but clearly reproduced as images taken from the manuscripts. 
an ordeal. ${ }^{146}$ Shortly after the editio princeps, a descriptive study of the text, detailing its contents, was published, rendering it more intelligible and also contributing to its wider use by scholars. ${ }^{147}$ Since then, al-Qalqashandì's manual has become a central resource for any researcher dealing with diplomatics. Several sections were translated during the last century ${ }^{148}$ and non-Arabists, particularly those interested in diplomatic relations, have called for a full translation of the work. 149

After the completion of his manual, al-Qalqashandī recycled parts of Șubh $a l-a$ sh $\bar{a}$ in another book that also focus on secretaryship, but differ from the point of view of the issuer's status. At the same time, these recycled parts introduce some new elements not found in Șubh al-a sha $\bar{a}$. The work deals with documents issued for or addressed to the caliph. Entitled Ma'äthir al-inäfa fi ma'ālim al-khilāfa, al-Qalqashandī completed the book around 819/1417. It was published by 'Abd al-Sattār Farrāj in $1964 .{ }^{150}$ Even though it is more limited in scope than Șubh al-ashhä, Màäthir al-inäfa remains a useful source on correspondence. About one year later (821/1418), al-Qalqashandī completed a two-volume abridgment of Șubh al-aśshà entitled Daw' al-șubh al-musfir wajanā l-dawh al-muthmir; only the first volume is still available. In the preface, he explains that the book is a response to a request made by the then head of the chancery who wanted a shorter version of Șubh al-a sha a, one that would be easier to consult. The first volume that has been preserved appeared in print in 1906, before his opus magnum. ${ }^{151}$ Despite the length of time it has been avail-

146 On the structure, see Van Berkel, The attitude. The publication of detailed indices now facilitates the consultation: al-Baqlī, Fahāris.

147 Björkman, Beiträge. See also 'Abd al-Karīm (ed.), Abū l-'Abbās al-Qalqashandī.

148 The following references are limited to those that offer a translation of documents linked to diplomatic relations between the Mamluks and other powers: Canard, Le Traité; Canard, Un traité; Dölger, Der Vertrag; Gabrieli, Trattato; Holt, Early Mamluk diplomacy; Vermeulen, Le Traité d' armistice entre le sultan Baybars et les Hospitaliers; Vermeulen, Le Traité d' armistice; Vermeulen, Timur Lang.

149 Recently, this invitation has been answered, at least in part. See al-Qalqashandī, Selections. This translation only considers some of the initial chapters, unfortunately those that do not relate to the drafting of documents. As early as 1993, Maria Pia Pedani translated the section dealing with truces. See Pedani, La dimora della pace.

15 O Al-Qalqashandī, Ma'äthir al-inäfa. The discovery of a second manuscript (a presentation copy, probably a holograph, i.e., entirely in the author's handwriting) was announced by Kafesoğlu, Kalkaşandî'nin bilinmeyen bir eseri.

151 Al-Qalqashandī, Daw' al-Subḥ, edition based on MS A2603 (Istanbul, Topkapı Sarayı Müzesi Kütüphanesi). Another copy was recently identified and appears to be a presentation copy, probably a holograph: MS 'Ayn 1122, Tehran, Kitābkhāna-yi Millī-i Jumhūrī-i Islāmī-i İrān. See Bauden, Maqriziana XIII 214 and 216. 
able, its importance in the field of diplomatics has yet to be assessed, though it has been established that the work contains some original elements. ${ }^{152}$

The next author of a manual on secretaryship is something of a mystery. For a long time, his work was incorrectly attributed to someone else and given a false title. It was referred to as al-Maqșid al-rafí al-munsha' al-hādì ila șinā'at al-insh $\vec{a}$, which is the title on the first page of the unicum (unique copy) (MS Arabe 4439, Paris, BnF); but in fact that title had been added by a western hand. It was attributed to a certain al-Khālidī—the name of one of its owners-; the work was also frequently referred to as Dīwän al-insh $\bar{a}$. The correct identification of the author, Muḥammad b. Muḥammad al-Saḥmāwī (d. 868/1463), and the true title of his work, al-Thaghr al-bāsim fi șināatat al-kätib wa-l-kātim, ${ }^{153}$ was made by an Egyptian student, Ashraf Muhammad Anas Mursī, who prepared a critical edition of the text as part of his dissertation, which was published in 2009. ${ }^{154}$ Thanks to this accurate attribution, it has been possible to establish that al-Sahmāwī enjoyed a long career in the service of the chancery-he worked some fifty years as a secretary for the state chancery and for several amirs - and thus he was knowledgeable in the art of secretaryship. According to the Ottoman bibliographer Kātib Çelebī (d. 1068/1657), al-Saḥmāwī completed his work in Sha'bān 846/December 1442-January $1443 .{ }^{155}$ For the redaction of al-Thaghr al-bāsim, al-Sahmāwī clearly relied on the work of his predecessors, particularly al-Qalqashandì's Șubh al-a'shā whose encyclopedic scope he adopted, though in a more concise manner. The contents of al-Sahmāwì's work would thus appear limited, if it were not for the updates that he offers on certain issues, like the paper utilized and the political context. With the edition published in 2009, the text, previously consulted by few scholars, became available to everyone interested in Mamluk diplomatics, though the editorial work is not devoid of imperfections. Shortly after al-Sahmāwī completed his book, he followed al-Qalqashandi's example and prepared a summary (probably for the same reason, accessibility), which he entitled al-'Urfal-nāsim min al-Thaghral-

$15^{2}$ See above, n. 35 .

153 This information was confirmed by Kātib Çelebi, Kashf al-zunūn i, col. $5^{21}$ (the author's nisba is incorrectly given as al-Sakhāwī). Nājī, Nuṣūṣ 249, followed by Karabulut, Dünya iv, 2654 (no. 716o/1), refers to a holograph copy of al-Thaghr al-bāsim in Tunis (Bibliothèque nationale, MS 4582 adab, formerly belonging to al-Ahmadiyya Library) dated 842/14389. The manuscript in question contains an anonymous poetic dīwān from Egypt. I thank Mounira Chapoutot for checking this manuscript for me.

154 Al-Saḥmāwī, al-Thaghr al-bāsim. Another edition of the same text was prepared by Khalīl Shahāda in the framework of a PhD dissertation presented in 1988 at the Université SaintJoseph in Beirut. However, Shahāda failed to identify the author and the correct title.

155 See Kātib Çelebi, Kashf al-z̧unūn i, col. $5^{21 .}$ 
bāsim, of which a lacunar copy is available. ${ }^{156}$ It still remains to be seen if some parts of al-Saḥmāwī's abridgment are as valuable as al-Qalqashandī's Daw ${ }^{\prime}$ alSubh proved to be.

The next author to contribute to our knowledge of Mamluk diplomatics is none other than al-Qalqashandī's son, Najm al-Dīn Muhammad (d. 876/1471), better known as Ibn Abī Ghudda. He occupied several functions in the judicial system, including the office of secretary for various amirs. At the end of his life, he devoted a treatise to the composition of letters, with a particular focus on correspondence exchanged by state officials (ikhwāniyyāt); ${ }^{157}$ he entitled this Qalāid al-jumān fì muștalah mukātabāt ahl al-zamān. The text has been preserved in a unicum (MS OR. 3625, London, BL) and a recent assessment ${ }^{158}$ has shown that, despite his heavy reliance on the works of his predecessors, the text includes some original elements. In a section dedicated to the correspondence issued in the name of the sultan and addressed to foreign rulers (fols. 13b-47b), Ibn Abì Ghudda focused his attention on the correspondence itself and the rules for issuing letters: specifically, the format of the paper, the formulas to be used (address, epithets, invocation), and their place on the document (number of sheets in the roll and the place where a given formula must be penned). Ibn Abì Ghudda also shows his preference for the external elements of letters, like the shape of the document, while his predecessors concentrated on the internal elements that constituted the letters themselves.

The analysis of the treatise composed by al-Qalqashandi's son proves that it is necessary to appraise similar, still unpublished texts, if we wish to expand our knowledge of Mamluk diplomatics, particularly for the later periods, for which time we have few chancery manuals. The following three works might contribute to this effort. The first one, al-Tibyān fi iștilāh a ahl al-zamān, was written by a certain al-Halabi who is characterized, on the title page of the unicum, as a secretary at the chancery in Cairo. ${ }^{159}$ The dates mentioned for some of the documents he quotes help us place his activity in the 770 os-8os/137os-8os.

$15^{6}$ MS $1315^{8}$ zāy (Cairo, Dār al-Kutub). This holograph copy is acephalous and contains 107 fols. Al-Sahmmāwī also authored a poem (urjūza) on calligraphy: Biḍ̄áat al-mujawwad fi l-khațțwa-ușülihi. See al-Baghdādī, İdāh al-maknūn i, col. 185 (the author's nisba is incorrectly given as al-Sakhāwī). See the editio princeps in Ḥabīb Efendi, Hattve-hattâtîn 278-85; new edition in Nājī, Nuṣuṣ $249-5^{8}$ (where the author's nisba is given erroneously as alSinjārī).

157 On these, see Bauden, Ikhwāniyyāt letters.

158 See Bauden, Like father.

159 MS Mf72, Berlin, Staatsbibliothek. His name is given as Shams al-Dīn Abū 'Abdallāh Muhammad al-Ḥanafi. He was in fact one of the clerks who recorded answers to petitions presented to the sultan and prepared the minutes (ahad al-muwaqqiin bi-l-dast al-sharîf). 
The book opens with a rather long and detailed section on correspondence addressed to foreign rulers. ${ }^{160}$ The second work, Muzìl al-ḥaşrfímukātabāt ahl al-'așr, is a handbook composed by an unknown author-his name does not appear on the title page or in the introduction. We can establish that he was active at the beginning of the ninth/fifteenth century, because he specifies in the preface that he composed his work for Ya'qūb b. al-Mutawakkil I, i.e., one of the Abbasid caliph's sons. Preserved in two copies, it relates to the correspondence issued by the chancery and addressed to each of the three levels (i.e., the caliph, sultans, and the administration). ${ }^{161}$ The third book, al-Murüj al-zakiyya fi tawshiyat al-durüj al-khițābiyya, was composed by an unidentified author, Ibn al-Hanbalī, whose death took place in or around 859/1455. ${ }^{162}$ Thus far, three copies have been identified in three libraries: El Escorial, ${ }^{163}$ Tunis, ${ }^{164}$ and Riyadh. ${ }^{165}$ While it is mainly concerned with ikhwāniyyāt letters, the text addresses some issues linked to correspondence with non-Muslim (mainly Christian) rulers. ${ }^{166}$

In addition to the works of Mamluk secretaries, we must not overlook the works of their counterparts in the eastern and western Muslim world. The treatise composed by Mūsā b. al-Ḥasan al-Mawșilī (d. 699/130o), al-Burd almuwashshā fi șināat al-insh $\bar{a}^{\prime}$, is an engaging case. ${ }^{167} \mathrm{Al}$-Mawșilī was the son of a secretary working at the Mamluk chancery. Around 66o/126o, he relocated to Yemen, where he became the head of the Rasulid chancery until his death. His treatise was conceived as a vademecum intended for clerks active in the same field. Though he did not record full copies of letters, the guidelines and formulas he describes help us understand the rules applied by the Rasulid side when addressing foreign rulers, though we must bear in mind that al-Mawșili received his education in Mamluk Egypt.

\footnotetext{
160 Ms Mf72, Berlin, fols. 1b-8a.

161 Ms Árabe 566 (San Lorenzo de El Escorial, Biblioteca de El Escorial); Ms Petermann 299 (Berlin, Staatsbibliothek).

162 His full name was 'Abdallāh b. Muhammad al-Zakīl-'Izzī/al-Ghazzī al-Ḥanafî. The author's name is incorrectly given as Ibn Ḥatlab (?) by al-Baghdādī, Ị̇āḥ al-maknūn ii, col. 470; Hadiyyat al-ārifin i, col. 468; and Kaḥhāla, Mújam al-mu'allifin ii, 284 (no. 8282) and 285 (no. 8292).

163 Ms Árabe 557, San Lorenzo de El Escorial, Biblioteca de El Escorial (dated 897/1492). See Brockelmann, Geschichte, Sup. ii, 915 (no. 7).

164 MS 4766, Tunis, Dār al-Kutub al-Wațaniyya, fols. 220-78 (dated 1215/18oo-1). See Manșūr, Fihris 108. My thanks to Marlis Saleh for checking this reference for me.

165 MS 471, Riyadh, Maktabat Jāmi'at al-Malik Sa'ūd (tenth/sixteenth century).

166 See Ms Árabe 557 (El Escorial), fols. 61b-62a (ahl dār al-harb).

167 See al-Mawșilī, al-Burd al-muwashshā. For a presentation of the work and its author, see Vallet, Mūsā b. al-Ḥasan al-Mawșilī.
} 


\subsection{Collections of Letters}

In addition to the chancery manuals, another category of texts which were purely descriptive also contributed to the preservation of copies of documents; these were collections of sample letters composed by secretaries active at the chancery (dīwān al-insh $\bar{a}$ ) — either the state chancery of Cairo, or a local one, like that in Damascus, Aleppo, or Hama. These secretaries gathered their production, of which they were particularly proud, and which they regarded as their letters, in their own right. These miscellanies were such a part of their literary output that they were regarded as personal works. By contrast, other secretaries copied the letters that reached the chancery and the responses that were redacted anonymously. Most of the time these collections covered a longer period, that is, the activity of several secretaries who, in some cases, are named. Whatever category these collections belonged in, their aim was to offer exemplary stylistic characteristics, like the summa dictandi of medieval Europe. ${ }^{168}$ They inspired-but also elicited the admiration of-contemporaries and future secretaries. As noted, in some ways, this recording activity replaced the registering of incoming and outgoing letters at the chancery and contributed to the preservation of copies that would have been lost otherwise. While these texts were not exclusively composed of samples of correspondence exchanged with other rulers, they are as instrumental as the chancery manuals for the study of various aspects related to diplomatics. ${ }^{169}$ These types of collections are usually known as munsha'ät (i.e., collections of inshä), though this term is not attested in the Arabic sources. ${ }^{170}$ Mamluk secretaries were also inclined to register the documents they composed-and those which prompted them to write responses - in their commonplace books. ${ }^{171}$ These texts present yet

168 Camarigo, Ars dictaminis; Grévin, Rhétorique 130-2.

169 They usually also include deeds of nomination, letters between various levels of the administration (ikhwāniyyāt letters), marriage contracts, etc.

170 Modern researchers seem to have borrowed the term from the Persian literary traditionfrom which it later passed into Ottoman usage-, where it is attested in the titles of such collections.

171 Known as tadhkira (something that helps memory), these were usually chronologically arranged multi-volume works; the author would regularly record his production and the results of his readings and start a new volume when the preceding one was filled. For instance, al-Qalqashandī quotes the forty-sixth volume of Ibn Faḍl Allāh's tadhkira, in which he found a copy of a document (Șubḥ al-a shā vii, 229). Another well-known example of this kind of work relates to another secretary, al-Ṣafadī (d. 764/1363), whose takhkira covered forty-nine volumes (several copies have been preserved; Élise Franssen is currently working on it). Al-Qalqashandī, Șubh al-a'shā xiv, 7o, also refers to Ibn Manżūr's (d. 711/1311) Tadhkirat al-labīb wa-nuzhat al-adīb, which, in spite of the title, must have been a collection of documents he composed and thus not a tadkhira in its own right. 
another opportunity to identify letters related to diplomatic exchanges, either from the Mamluk side or from their correspondents (like the Timurids or the Ottomans, to mention only the most important), who utilized other epistolary traditions. For the Mamluk period and the Mamluk point of view, the vast majority of the epistolary collections to which al-Qalqashandī refers in his opus magnum, i.e., those covering the seventh-eighth/thirteenth-fourteenth centuries, are now considered lost. ${ }^{172}$ For the ninth/fifteenth century, we can cite several examples here.

In the category of personal collections containing diplomatic correspondence, Ibn Hijja's (d. 837/1434) ${ }^{173}$ Qahwat al-insh $\bar{a}$ ' is unique in terms of quality, but also in the sense that it is the only personal collection of its kind that has reached us from the Mamluk period. The author, born in Syria, was well-known for his literary prose and poetry, and for his acquaintance with the secretary of the governor of Hama. When the governor, Shaykh al-Mahmūdī, became sul$\tan \left(r .815^{-24} / 1412-21\right)$, he brought with him his secretary, whom he placed at the head of the chancery in Cairo. Ibn Hijja's acquaintance with him proved beneficial, as he was immediately designated as munshi of the state chancery; this meant that he penned documents (deeds and letters) upon request. Ibn Hijja remained in office for the duration of al-Mu'ayyad Shaykh's reign and that of some of his successors, until his dismissal around 827/1424. His Qahwat al-insh $\bar{a}$, in which he gathered the deeds that he composed as well as the incoming letters and the responses he penned, covers his activity at the chancery in chronological order: the first document is dated 815/1413 and the last one is from $827 / 1424$. Its author was a unique witness of the diplomatic exchanges during this period, not only because he was a theorist of rhetoric, which he put to good use in the documents he wrote, but also because he provided details of elements related to diplomatics (the format of paper, the color of the ink, the presence of a motto or the impression of a seal). His work thus offers a rare glimpse into a period during which al-Qalqashandī had already written his major work. Rudolf Veselý was the first to scrutinize Ibn Hijja's work. ${ }^{174}$ In 2005 , he published a critical edition of the Qahwat al-insh $\bar{a}$, leaving little space for criticism. ${ }^{175}$ This collection contains no fewer than forty diplomatic letters, usually incoming correspondence with replies composed by Ibn

\footnotetext{
172 This is, for instance, the case for Ibn Manẓūr's Tadhkirat al-labīb. See al-Qalqashandī, Șubh al-ashā xiv, 70; Björkman, Beiträge 77 .

173 For his biography and production, see Stewart, Ibn Hijjah.

174 Veselý, Eine neue Quelle; Veselý, Eine Stilkunstschrift; Veselý, Ein Kapitel.

175 Ibn Hijja, Das Rauschgetränk. For his edition, Veselý did not take into consideration the manuscript held in Algiers (Bibliothèque nationale, MS 1898); this is the oldest complete
} 
Hijja. These are in numerical order as follows: Ayyubids of Hisn Kayfã (seven incoming and six outgoing letters), Qara Qoyunlu (five incoming and five outgoing letters), Rasulids (two incoming and three outgoing letters), Ottomans (one incoming and two outgoing letters), Qaramanids (one incoming and two outgoing letters), khans of the Golden Horde (two outgoing letters), Timurids (one incoming and one outgoing letter), Hafsids (one outgoing letter), and Aq Qoyunlu (one outgoing). This sample of forty letters, all by one author, shows the frequency of the exchanges between these dynasties and the Mamluk sultanate during a short period of time (twelve years) and highlights the quantity of material that must have existed for the Mamluk period but which is now lost. Its contents have scarcely been studied, either in historical or diplomatic terms. ${ }^{176}$

MS Arabe 4440 (BnF, Paris) belongs to the anonymous category of collections of models; it has been known for more than a century, though scholars only started to investigate it in the 196os. In an article in 2007, I studied the contents of this composite text, and provided a full list of the letters it preserves. ${ }^{177}$ This collection is divided into four parts, and it is in the last one that the compiler, who probably worked at the chancery in Cairo up to the beginning of al-Ashraf Qāytbāy's reign, collected a series of sixty-two letters, mostly dated between $837 / 1433$ and $873 / 1468$. The compiler provides physical details of certain elements of these letters (the format of the paper, the presence of seal impressions, the color of the ink, the presence of the sender's motto), all of which are further evidence that he had access to the original documents and

dated copy available (dated, on fol. 255b, 30 Jumādā I 840/10 December 1436, three years after Ibn Hijja's death). See Fagnan, Catalogue 543-4.

The Shams al-maghrib fi l-murqis wa-l-muțib attributed to Ibn al-Damāmīnī (d. 828/ 1425) and catalogued as such by Ahlwardt, Verzeichniss viii, 579-8o, no. 8643 (Berlin, Staatsbibliothek, Ms Sprenger 1223) is just another partial copy of Ibn Hijja's Qahwat alinsh $\bar{a}$. The manuscript is lacunar at the beginning and the end. Although the copy begins with three commendations (taqriz) not found in Qahwat al-insh $\bar{a}$, all the documents are given in the same order with some lacunae in between. In the list that follows, the no. of the document in Veselý's edition is between parentheses: fols. $2 b$ (58), 6a (59), $7 \mathrm{a}(61), 8 \mathrm{~b}$ (62), 9a (63), 9b (64), 10a (66), 10b (67), 12a (67a), 13a (68), 14a (69), 14b (70), 16b (71), 17a (72), 18a (73), 19b (74), 2ob (75), 21a (76), 22b (77), 24a (78), 25b (79), 26a (8o), 27a (81), 29a (82), 30a (83), 31a (84), 31b (86), 32b (87), 34a (88), 35b (89), 37a (9o), 38a (90a), 39a (91), $42 \mathrm{~b}$ (92), 43a (93), 44a (94), 46a (95), 48a (96), 48b (97-8), 49b (99), 5ob (100), 53b (101), $54 \mathrm{~b}(102-3), 55 \mathrm{a}(104-5), 55 \mathrm{~b}(106), 57 \mathrm{a}(107), 58 \mathrm{a}(108), 59 \mathrm{~b}(111), 6 \mathrm{ob}(112), 61 \mathrm{~b}(112 \mathrm{a}), 62 \mathrm{~b}$ (112b), 63b (113), 64a (114), 66a (115), 68a (116), 7ob (117), 72a (121b), 76b (121a), 81b (121j).

${ }_{17} 6$ Yüksel Muslu, The Ottomans has studied Ottoman letters. The Qahwat al-inshä ' is also the focus of my article on the reconstruction of a Qara Qoyunlu letter in this volume.

177 Bauden, Les Relations. 
accurately took note of these details upon their arrival or issuance. He may in fact have been the secretary who penned the correspondence (munshi'), and, like Ibn Hijja, wanted to keep a record of his production. The letters cover a wide range of rulers, and thus bear witness to the animated exchanges that occurred in the period considered; these exchanges took place with the following: Ottomans (three incoming and ten outgoing letters), ${ }^{178}$ Timurids (four incoming and six outgoing), Qara Qoyunlu (two incoming and three outgoing letters), Hafsids (two incoming and three outgoing letters), Qaramanids (three outgoing letters), Ayyubids of Hiș̣n Kayfā (two incoming and one outgoing letter), Rasulids (three outgoing letters), Nasrids (two incoming letters), khans of the Golden Horde (two outgoing letters), Muzaffar Shāhids of Malwa (one incoming and one outgoing letter), Aq Qoyunlu (one outgoing letter), Takrūr (one outgoing letter), khans of the Crimea (one incoming letter), ${ }^{179}$ the Muslims of Lisbon (one incoming letter), and the Cypriots (one outgoing letter).

Some of the letters have been studied. In 1940, George Colin was the first to publish a group of five letters related to the West (the two Hafsid and the two Nasrid letters, as well as the letter by the Muslims of Lisbon, all of which were addressed to the Mamluk sultan). ${ }^{180}$ In 1958, Ahmad Darrāj edited a letter sent by the sultan of Malwa and the response issued by al-Ashraf Qāytbāy. ${ }^{181}$ For half a century, this manuscript was largely neglected until it stimulated my interest and I devoted an article to it in 2007. Some significant parts of it then became the subject of Malika Dekkiche's dissertation, which focuses on the diplomatic relations between the Mamluk sultanate, on one side, and the Timurids, Qaramanids, and Qara Qoyunlu on the other. In the context of her work, she edited all the letters linked to these dynasties. ${ }^{182}$ Since then, she has published several studies and editions of these letters. ${ }^{183}$ Despite these publications, the full corpus of letters certainly deserve to be published in its entirety.

${ }_{17} 8$ Contrary to the header of letter no. vi, this letter was not addressed by Murād II to alAshraf Barsbāy, but vice versa, as noted by Yüksel Muslu, The Ottomans 315, n. 46.

179 Letter XLV was incorrectly attributed to the Qaramanids in Bauden, Les Relations.

180 Colin, Contribution. In the meantime, the letter of the Muslims of Lisbon was edited by Zayyāt, Athar unuf. Maria Filomena Lopes de Barros's article in the present volume focuses on this letter.

181 Darrāj, Risālatān. John Meloy thoroughly studies both letters in the present volume.

182 Dekkiche, Le Caire.

183 Dekkiche, Correspondence; Dekkiche, New source; Dekkiche, The letter (Qara Qoyunlu letters edited); Dekkiche, Crossing the line (Qaramanid letters edited). In addition to the articles of Lopes de Barros and Meloy in the present volume, Mounira Chapoutot-Remadi, Rémi Dewière, and Éric Vallet deal with some of the letters in the manuscript, at least in part. 
The recent identification of another copy of the same text in Algiers will certainly contribute to the resolution of some of the problems that arose from the Paris copy. ${ }^{184}$

Other collections of models have yet to be assessed, so we do not yet know if or how they might prove useful to Mamluk diplomatics. Ms 663 (Leipzig, Universitätsbibliothek) is an interesting case. This manuscript consists of a miscellanea of documents that were composed by secretaries, including, in some cases, those by the unknown compiler (musațtir). ${ }^{185}$ The most recent documents are dated or datable to the $870 \mathrm{O} / 1465^{-75}$, making this collection a perfect contemporary of Ms Arabe 4440. One response addressed to the Qaramanid amir in $871 / 1467$ (fols. 31b-32b) offers details about the format of the paper used and the gifts for the amir that were dispatched with the Qaramanid envoy who was returning home.

The practice of collecting models of documents was also widespread in the Persian and Ottoman epistolary traditions, where these were known as munsha'ät/münşe'ät. As in the Mamluk tradition, these were collections of the epistolary production of some of the most prominent actors working for the chancery. In some cases, they brought together some of the most significant letters that were exchanged with other rulers over a given period of time. ${ }^{186}$ These collections thus prove instrumental in broadening the corpus of letters exchanged with the Mamluks. While on the Persian side, the harvest has proved unproductive thus far, ${ }^{187}$ the situation is more encouraging for the Ottomans. In this context, the main source is represented by Ferīdūn Beg (d. 991/1583),

184 MS 1899, Algiers, Bibliothèque nationale. The manuscript was described by Fagnan, Catalogue 544 as an anonymous collection of letters, mainly from rulers. He also thought that the compiler was an Egyptian who probably worked at the chancery. In comparison with the Paris manuscript, the copy in Algiers is lacunar and in great disorder. It only contains the following letters (references are to the numbers in Bauden, Les Relations and the corresponding page numbers in the Algiers manuscript): letter XXI $=78-81$, letter XII $=84-7$, letter XXIII $=83$, letter XXXV $=4-7$, letter XXXVII $=1-3$, letter XXXIX $=66-7$, letter XLIII $=$ $96-100$, letter XLV $=101-2$, letter XLVII $=88-95$, letter XLVIII $=70-7$, letter L $=104-6$. Inter estingly, this manuscript belonged to the well-known scholar al-Zabīdī (d. 1205/179o) who settled in Egypt. The manuscript thus passed from Egypt to Algeria at a rather late date.

185 Vollers, Katalog 209-11, describes the contents of the manuscript. Unfortunately, the title and the name of the compiler on the title page were erased. A later owner substituted the erased title for a questionable title: al-Durar al-manthürät.

186 For an overview of collections of epistolary models in Persian and Ottoman, see, respectively, Storey, Persian literature; Uzun, Münşeat.

187 For the Timurid period, Navā'î has reviewed most of the Persian and Ottoman munsha'ät in print or still unpublished. See Navāì̄, Asnād. The author only lists two fatḥnāmas sent to the Mamluks to announce the news of a conquest; these fathnämas were found in a collection of letters dating from the Safavid period: one by the Timurid Shāh Rukh 
who worked at the Ottoman chancery from $981 / 1573$ to $984 / 1576$, then from $989 / 1581$ to his death. In his capacity as nişāncı (seal holder), his tasks included supervising the dī $\bar{a} n$ 's archives. His functions meant he had permanent access to a vast repository of documents. This led him to copy some of the most significant documents related to the diplomatic relations between the Ottoman sultans and several of their counterparts, as early as the end of the eighth/fourteenth century. ${ }^{188}$ His work, entitled Münşe'āt-i selāțīn [Official letters of the sultans], has been available in an uncritical edition since the mid-nineteenth century. ${ }^{189}$ Celia J. Kerslake has studied the letters addressed by Selīm I to Qānșawh al-Ghawrī. ${ }^{190}$ More recently, Cihan Yüksel Muslu has analyzed all the letters received from and sent to the Mamluk sultans in her book on OttomanMamluk diplomatic relations. ${ }^{191}$ Other collections remain in manuscript form, but certainly merit investigation. ${ }^{192}$ Among these, Ms Arabe 4434 (BnF, Paris) ${ }^{193}$ contains several copies of Ottoman-Mamluk letters, some of which were mentioned by Yüksel Muslu, though these remain unpublished. ${ }^{194}$

In addition to the Ottomans, there may yet be some unexpected discoveries to be made, as the following example demonstrates. An anonymous collection entitled Zuhrat al-nāzirīn wa-nuzhat al-nādhirīn, drew Rudolf Veselý's atten-

(r. 8o7-5o/1405-47) and the other by Aq Qoyunlu Uzun Hasan (r. 861-82/1457-78). See Navā'̄i Asnād 208-14, 561-7o. Melvin-Koushki, The delicate art, is a study of Uzun Ḥasan's fatḥnāma.

188 The first dated document in his work is from 793/1391; we must bear in mind that the correspondence for the early Ottoman reigns, those up to Murād II, as noted, is problematic. See above n. 127.

189 Ferīdūn Beg, Mecmū'a-yi münşe'āt-i selāțīn. As noted by some scholars, there are discrepancies between the first edition in 1264-5/1848-9 and the one that followed in 12745/1857-9: some letters are missing in the former. See Kerslake, The correspondence 220, n. 8.

190 Kerslake, The correspondence. She also refers to one additional letter identified in a composite manuscript. See ibid., 220, n. 7 .

191 Yüksel Muslu, The Ottomans.

192 See Kerslake, The correspondence 221, n. 10.

193 According to de Slane, Catalogue 707, the manuscript is dated 877/1473. In fact, he refers to the date that appears on fol. $17 \mathrm{ob}$, though this date corresponds to the date of the last document reproduced and not the manuscript itself. In truth, this manuscript is a composite: it contains two parts, written by two hands, each bearing different ownership marks. The first part (fols. 1-171) is undated and mainly consists of two collections of letters, the first related to the Khwarizmshahs and the second to the Ottomans, the last being from 877/1473; the second part (fols. 172-222) is composed of a collection of epistolary models in Persian that ends with a collation note dated 843/1440.

194 BnF, ms Arabe 4434, fols. 13ob-133b, 133b-138b, 139a-141*a. The following letters are not mentioned in her study: fols. $165 \mathrm{~b}-168 \mathrm{a}$ (Ottoman letter and response), $168 \mathrm{~b}-16 \mathrm{gb}$ (Ottoman letter and response). 
tion. ${ }^{195}$ Preserved in a unicum in Leiden (MS Or. 1052), among other documents, the text contains thirty-one letters exchanged between the Qaramanids and the Mamluks. According to Veselý, the compiler recorded letters that were in the archives in Konya, though it is more likely that he worked at the chancery and made copies of the letters that reached it, along with those drafted in reply to them. These letters represent another significant example of the correspondence between the Mamluks and the Qaramanids, which the former mainly regarded as vassals and buffers against the Ottoman expansion. Despite the flaws in the copies-dates are rarely mentioned, hindering a chronological reconstruction of the collection, except on the basis of internal references; and the initial parts of the letters (invocatio and intitulatio) were not considered-, this collection certainly deserves a thorough study and edition.

\section{$5 \quad$ Mamluk Diplomatics}

The two preceding sections confirm that original Mamluk documents have been preserved in limited numbers, but with some variety, and that copies are available in chancery manuals, formularies, and collections of letters with the same characteristics. It is thus fair to wonder why we do not have a manual of Mamluk diplomatics, given that scholars have focused on the diplomatics related to other dynasties. ${ }^{196}$ There are several reasons that may explain this. First, the original Mamluk documents that have been available in editions and translations were mostly published between the mid-nineteenth and mid-twentieth century. During this period, reproductions of documents were seldom added to the editions because of the financial costs of such an enterprise. Most editors were interested in seeing the documents published because of their historical significance. They did not pay much attention to the physical details of the documents themselves or to some parts of the text; indeed, they may have considered these aspects meaningless. For instance, if measurements were given, they were for the size of the whole document, but not the size of its constituent parts, i.e., each sheet of paper in the roll. Moreover,

\footnotetext{
195 In Veselý, Ein Briefwechsel, the title is erroneously given as Zumrat al-nāzirīn wa-nuzhat al-nädirinn. The way the first word of the title is written on the first page may be misleading; the correct form is given by Kātib Çelebī, Kashf al-žunūn ii, 962, who probably based his description on this very manuscript.

196 For a general introduction, see al-Khūlī, Mudākhālāt. For works dealing with the diplomatics of a specific dynasty, mostly (properly) based on original documents, see Reychman and Zajączkowski, Handbook (Ottomans); Roemer, Staatsschreiben (Timurids); Keçik, Briefe und Urkunden (Aq Qoyunlu).
} 
interest in the diplomatic rules given by chancery manuals only developed after the publication of al-Qalqashandì's Șubh al-a'shā. ${ }^{197}$ Scholars only began to produce editions of texts with full diplomatic commentaries and physical descriptions from the 195 os. ${ }^{198}$ Since then, diplomatists have scarcely considered consulting the original documents, rather they have trusted in the works of their predecessors-despite the faults just outlined. A new generation of scholars has now taken the next step, which is to go back to the original documents in order to (respectfully) check the work of the pioneers and fill in the blanks they left in their analyses. ${ }^{199}$ Thus, the time seems ripe to outline the results of this new scholarship, i.e., what has been done and what still needs to be accomplished-where are we. In fact, the general sketch that follows cannot be regarded as a manual of Mamluk diplomatics for documents linked to diplomatic exchanges; rather, it is intended to serve as a contribution to the issue. In so doing, we follow the two major steps heeded by the diplomatists in their analysis of documents, i.e., we examine the form of the document (external and internal characteristics), and its genesis or drafting. This is preceded by the various types of documents that should be taken into consideration for the Mamluk period and ends with a brief section on the tradition of the documents, i.e., what happened to them after their issuance.

\subsection{A Brief Typology of Documents}

The documents related to diplomatic exchanges in medieval Europe that can be found in archival repositories increased in number along with the widespread use of paper and the recognition by various powers of the importance of writing and the preservation of this written activity in archives. Historians of diplomacy can thus study the whole gamut of these written remains. Some are clearly related to diplomatic activity, while others are related more

197 This is the case for the majority of the original documents that are preserved in Barcelona, Florence, and Venice, as we saw above.

198 For the Mamluk period, John Wansbrough was the first to apply diplomatic analysis to the documents he studied; this is true, even though his publications (see the bibliography) are not exempt from fundamental flaws, particularly in relation to incomplete physical descriptions and the identification of the category to which the documents belonged. For the appraisal of Wansbrough's work, see Rizzo, Le Lys et le Lion.

199 The documents in Florence, previously published by Amari and Wansbrough, have recently been analyzed in this way. See Rizzo, Le Lys et le Lion. The same process has been launched for the documents held in Barcelona under the direction of Roser Salicrù i Lluch in the framework of a collaborative project involving F. Bauden and A. Rizzo for the Mamluk documents, M. Ouerfelli for the Hafsid materials, Ana Labarta for the Nasrid documents, and Mercè Viladrich for the Merinid ones. 
to what took place behind the diplomatic scenes. These documents include diplomatic letters, treaties, lists of gifts, safe-conducts, procurations (i.e., the powers of attorney granted to ambassadors to negotiate in the name of his ruler), letters of credence, instructions, orders of payment related to envoys, reports of ambassadors, accounts of travel expenses, and ambassadors' correspondences. ${ }^{200}$ Unfortunately, the existence of the full range of these sorts of documents cannot be confirmed for the Mamluk period. Our lack of knowledge is due to the paucity of evidence (originals or copies) and the lack of accounts in the specialized literature (chancery manuals and formularies) and narrative sources. However, the deficit of evidence cannot be used as an argument that these sorts of documents did not exist in the Mamluk diplomatic tradition. ${ }^{201}$

The categories of documents that relate to diplomatic exchanges in the Mamluk period include the following:202 truces (hudna, pl. hudan), oaths (yamīn, pl. aymān), letters (mukātaba, pl. mukātabāt), ${ }^{203}$ safe-conducts (amān, pl. amānāt), passes for foreign envoys (yarligh, pl. yarāligh), instructions to emissaries (tadhkira, pl. tadhākir), and finally, lists (qā̉ima, pl. qawā'im) of gifts. The chancery manuals and formularies describe most of these categories, detail the rules for their redaction, and give some examples. Unfortunately, we do not have original preserved documents in all of these categories, thus, we have no way to compare them with the prescriptive works. We know of another kind of document, but only because original examples are available in European archival repositories; these are lists of gifts and are not described in the chancery manuals. Our knowledge of them, from a diplomatic point of view, relies entirely on the items preserved in the European archives. ${ }^{204}$

200 Péquignot, Les diplomaties occidentales 48.

201 For instance, the argument of absence was used with regard to a specific kind of private document, the contract for fluvial and maritime transportation; its absence in the preserved documents led to the conclusion that such contracts, though described in formularies, were not in fact issued. This conclusion was disproven when an example of such a contract was identified and published. See Bauden, Le Transport de marchandises.

202 For a taxonomy of documents issued by the chancery in general, see Björkman, Diplomatic 302-4, largely inspired by Björkman, Beiträge which, in turn, is entirely based on al-Qalqashandī's Șuḅ̣ al-aśsha.

203 Sometimes also referred to by the more general term kitāb or mithāl, the latter also meaning, according to the context, "order."

204 Gifts in the Mamluk diplomatic tradition have recently drawn the attention of scholars. See, in particular, Muhanna, The sultan's new clothes; Behrens-Abouseif, Practising diplomacy. However, the lists of gifts, which were appended to diplomatic letters issued by the Mamluk chancery, have not been considered sufficiently. On these, see Bauden, Lists of gifts. 
By contrast, some categories fell into disuse because their function was, at least occasionally, transferred to other types of documents. In the wake of Frankish rule in Syria and as relations between the European states and the Mamluk sultanate evolved from one of conflict to one characterized by economic exchanges, the chancery had less need for truces and their correlative form of confirmation, i.e., oaths. ${ }^{205}$ In order to apply the negotiated trade agreements, so merchants could enjoy commercial benefits, the chancery started, from the beginning of the eighth/fourteenth century, to use another kind of document: the administrative decree (marsūm, pl. marāsim) ${ }^{206}$ These were certainly not reciprocal like truces, but unilateral, administrative decrees that belonged to the category of documents issued by the chancery for a specific purpose: they transmitted orders to representatives of the sultanate who were responsible for their implementation. Although these documents were meant for internal use, the European states increasingly requested copies of the decrees for their own records, a practice that explains their presence (as originals or in translation) in the archives of these European states. ${ }^{207}$ In the same way, the use of the safe-conduct witnessed a similar evolution. While a document of safe-conduct was initially a specific document issued according to a set of rules described in the chancery manuals, over time, this category of document was abandoned, though its juridical function - to grant safe-conduct to a specific person or community - was included in other categories of documents. These documents included letters addressed to European states and administrative decrees issued in favor of their subjects residing in the territories of the sultanate. ${ }^{208}$

\footnotetext{
205 See Köhler, Alliances.

206 On administrative decrees in the Mamluk period, particularly responses to petitions, see Stern, Petitions. For those linked to European states, see Wansbrough, A Mamlūk commercial treaty.

207 Together with the subcategory of the murabba' (square decree), which refers to the form of
} the document (i.e., a full sheet of paper, thus a rectangle ( $\left.m u r a b b a^{c}\right)$ folded in two). Called maraba in Italian translations, these were minor decrees that were differentiated by the Venetians, who referred to the marāsim as commandamento longo. See Rossi, Ambasciata 127. On the murabba' decree, see Richards, A Mamlūk emir's 'square' decree, and, for recent research, Hirschler, From archive to archival practices, 14-5. The European states used the same practice (i.e., of requesting copies of administrative documents issued by the Mamluk chancery for internal use) with regard to letters addressed by the sultan to the governors, in which the sultan announced the accompanying decrees. See Rizzo, Le Lys et le Lion i, 207.

208 See Frantz-Murphy, Identity and security; Rizzo, Le Lys et le Lion 226-3o. This is not peculiar to Mamluk diplomatics. In the European documentary tradition, letters also 
This situation led to some confusion in the way a document issued by the Mamluk chancery was interpreted and identified. Decrees, for instance, were understood by European recipients in light of terms that prevailed in their documentary tradition, terms like treaties, ${ }^{209}$ capitulations, ${ }^{210}$ and privileges. Modern historians based themselves, in some cases, on the interpretation of documents by the local chanceries, who adopted the same descriptive terms, which further clouded the issue. ${ }^{211}$ In general, it is advisable to refer to these documents by the technical terms used by the Mamluk chanceries. ${ }^{212}$

Another element that needs to be taken into account concerns the issuing authority. It is generally assumed that documents related to diplomatic exchanges were all issued by the state chancery in Cairo. By the same token, it is taken for granted that foreign chanceries were only in contact with the Mamluk state chancery. Both assumptions are contradicted by documents and reports. In fact, intercommunication was predominantly established between the respective state chanceries, but lower-level figures occasionally also liaised with foreign powers. ${ }^{213}$ This alternative communication impacted the emanation of the documents, especially on the Mamluk side, where correspondence was highly codified. ${ }^{214}$

transmitted orders, which led to their preservation in the archives. See Guyotjeannin et al., Diplomatique médiévale 104-5.

209 Like the treaties, the decrees included clauses (shart, pl. shurūt $)$. This is one reason they were interpreted as treaties by their European recipients.

210 Hartmann, Die Islamisch-Fränkischen Staatsverträgen; Theunissen, Ottoman-Venetian diplomatics, chap. 2.

211 The term 'commercial decree' was used to define decrees issued in relation to benefits secured for the merchant community of a European state in the Mamluk sultanate; however, in the Mamluk chancery, these were not differentiated from administrative decrees.

212 As early as 1996, Maria Pia Pedani stressed that defining Mamluk documents with terms specific to the medieval European diplomatic tradition or their intrepretation by the local chancery which received them should be abandoned in favor of using terms specific to Mamluk diplomatics. See Pedani, La dimora 20.

213 For a case in which the executive secretary, who was in Syria, contacted the Venetian authorities, see Arbel, Levantine power struggles. For documents addressed by the Mamluk state chancery to the authorities of the city of Barcelona, see nos. 19-20 in the Survey, under Aragon. For letters addressed by the King of Aragon to various authorities on the Egyptian side, mostly governors of Alexandria and Damascus, see nos. 49, 66, 68, 72, 79, $83-4$ in the same Survey.

214 See Bauden, Ikhwāniyyāt letters. 


\subsection{Form}

In diplomatic terms, diplomatists consider the examination of a deed one of the two steps necessary for an analysis and correct interpretation. To begin, diplomatists examine the external and internal features of a document. The external features are essentially the support, the format, the layout, and the script. These must be scrutinized on the document itself, not from a reproduction. With regard to internal features, these define the elements that pertain to the text itself: the structure of the text, the means used to validate a document (seal, signature, etc.), the language, and the style. These elements do not require access to the original document, but to a good reproduction at least. 215

This brief outline of important features to note calls for a couple of remarks that are specific to Mamluk diplomatics. First, access to the original documents is not always granted by the repositories because these are old items that can be manipulated only in tightly controlled circumstances. While in theory this concern is fully justified, researchers should stress that it is almost impossible to study the external characteristics of a document without access to the original. Just as a codicological description of a manuscript can prove crucial to accurately dating the manuscript, a diplomatic description of a document is equally instrumental for its correct interpretation. While it is true that consulting Mamluk chancery documents can be challenging in practical terms (see fig. 1.3), it should not be an obstacle. Second, if researchers give up trying to access originals, our knowledge of Mamluk diplomatics will not continue to evolve. For more than a century, diplomatists and historians have been content to work on the basis of reproductions, and have missed and/or misinterpreted essential parts of the documents they were studying. This situation is no longer tenable and every effort to improve our understanding of Mamluk diplomatics should be encouraged.

\subsubsection{External Features}

For the issuance of documents, the Mamluk state chancery (dīwān al-inshà) mainly used two kinds of format: (1) the roll (darj, pl. durūj), longer than it was wide, is composed of one (or several) sheets (wașl, pl. awșāl) pasted one below the other, for a given format of paper (qaț, pl. $\left.a q t \bar{a}^{c}\right)$; and (2) the single sheet of paper, usually folded in two. The roll was the most widely used format for various categories of documents, including official correspondence with foreign rulers. The use of the single sheet folded in two was limited to very

215 See Guyotjeannin et al., Diplomatique médiévale 63. 
specific types of documents, like instructions to envoys (tadhkira). ${ }^{216}$ Given that diplomatic letters are the most commonly represented category in the originals that have been preserved, in the following lines, I address these exclusively. ${ }^{217}$

Paper was the only writing material used by the Mamluk chancery. Our knowledge of the production of paper in Egypt and Syria during the Mamluk period has improved since the publication of Geneviève Humbert's study, which is based on those manuscripts she was able to date and locate. ${ }^{218}$ Nevertheless, for a long time it was assumed that the paper supply for the Mamluk chancery was specific, i.e. that the paper intended for use for chancery documents was specially produced to meet its requirements. The production would thus have been separate from paper made for other purposes, like books. This assumption was largely based on the misunderstanding of an obscure passage in al-Sahmāwì's al-Thaghr al-bāsim. ${ }^{219}$ By reconsidering the data found in al-Qalqashandì's and al-Sahmāwī's manuals, and by examining some contemporary manuscripts-particularly the monumental Qurans commissioned by Mamluk sultans-, I have been able to demonstrate that the paper used by the chancery was not produced by a specific mill and that it was no different than that made for books. ${ }^{20}$ An examination of documents preserved in the European archives has also provided another meaningful detail: the Mamluk chancery used locally produced paper until the end of the sultanate, even though European watermarked paper was already available in Egyptian and Syrian markets. ${ }^{221}$ This practice seems to confirm that chancery secretaries

216 See al-Qalqashandī, Șubh al-a shā xiii, $79 \mathrm{ff}$. for a description of this category of document, including its shape.

217 We should emphasize that secretaries traditionally divided correspondence according to the rank of the issuer/addressee, giving precedence to the caliph, then the sultan, and finally to the appointees—-military and civil—and referring to the correspondence of each of these ranks with the following respective technical terms: khalifatiyya (letters to or from the caliph), sultāniyya (letters to or from the sultan), and ikhwāniyya (letters exchanged by appointees). For more detail, see Bauden, Ikhwāniyyāt letters. Theoretically, the caliph was the representative of religious authority. See Holt, Some observations. For an excellent overview of the evolution of the Abbasid caliphate in Cairo, see Banister, The Abbasid caliphate. Medieval diplomatics applies the same kind of distinction between documents according to the nature of the issuing authority, i.e., secular or religious, and their respective rank (regal, princely/seigneurial/communal, pontifical, episcopal, private). See Guyotjeannin et al., Diplomatique médiévale 104.

218 Humbert, Papiers non filigranés; Humbert, Un papier.

219 Humbert, Le manuscrit arabe.

220 Bauden, Paper formats.

221 See Bauden, L' Achat d' esclaves 272, n. 15. 
were not interested in issuing documents on European paper, whether for political $^{222}$ or economic reasons, ${ }^{223}$ or both.

It is well known that rolls were used for letters. The origin of this format goes back to antiquity and was adopted by Muslims when they conquered Egypt. ${ }^{224}$ From there, it spread to other regions of the Islamic world in the East and the West. ${ }^{225}$ In her contribution to this volume ("Diplomatics or Another Way to See the World"), Malika Dekkiche presents a brilliant synthesis of the rules applied by the secretaries for the diplomatic correspondence addressed to Muslim rulers. ${ }^{226}$ Based on her analysis of various chancery manuals of the Mamluk period, she explains in clear terms how the status of the addressee, as recognized by the Mamluk chancery, determined a set of rules that impacted the external and internal features of letters. As explained, rolls were composed of several sheets pasted one below the other. The width of the roll was thus determined by the sheets. The different widths (full sheet, twothird, half, one-third, quarter, ordinary) are known thanks to al-Qalqashandi and al-Saḥmāwī who referred to a standard (the cubit used to measure fabrics: dhirā' al-qumāsh). Until very recently, scholars relied not only on an incorrect calculation of this standard $(48.886 \mathrm{~cm}$ vs. $58.187 \mathrm{~cm}),{ }^{227}$ but also on an erroneous interpretation of the formats. In her study of the formats described by al-Qalqashandī and al-Sahmāwī, Humbert concluded that each format of a sheet detailed by the two Mamluk authors determined, as we saw, by its width, was specifically produced for the chancery. ${ }^{228}$ In fact, only a very limited number of formats of sheets (the largest ones) were made for the chancery. Each time a fraction of the full format is mentioned for the width of a roll, it just means that the full sheet was cut into the size requested. ${ }^{229}$ This example demonstrates how critical it is to undertake a physical examination of the origi-

222 Diplomatic letters are, of course, expressions of power.

223 For example, to support local paper mills.

224 The oldest Muslim diplomatic letter that has reached us is a roll from Egypt. Dated 18 Rajab 141/24 November 758, it was addressed by the governor of Egypt, Mūsā b. Kacb, to the king of the Nubians. Made of sheets of papyrus, each measuring $22-23 \times 53.5 \mathrm{~cm}$, its total length is $2,645 \mathrm{~m}$. The letter is now displayed at the Museum of Nubia in Aswan. See Hinds and Sakkout, A letter; Plumley, An eighth century Arabic letter.

225 The roll format was still used by the Almohad chancery. See Buresi, Les Plaintes.

226 See also the second volume of Dekkiche, Le Caire. The same work should now be carried out for non-Muslim rulers.

227 Consequently, all the measures given for the different sizes used by the Mamluk chancery are incorrect. See Bauden, Paper formats.

228 Humber, Le manuscrit arabe.

229 See Bauden, Paper formats. 
nals. $^{230}$ The layout of the text was another feature impacted by the rules summarized by Dekkiche. The text started after a number of blank sheets-a space called turra ${ }^{231}$ — which was determined by the rank of the addressee. The rank of the addressees also determined the interlinear space and the width of the right margin. ${ }^{232}$

Different styles of scripts were used in the chancery, which was a sort of laboratory in which calligraphers developed new styles. ${ }^{233}$ In recent years, various studies were devoted to calligraphic styles; these have contributed to our better understanding of their use at the Mamluk chancery. ${ }^{234}$ Other sources have also been discovered: albums displaying examples of the different styles were composed by calligraphers who also worked for the state chancery. ${ }^{235}$ However, the scripts featured in Mamluk documents have largely been neglected and certainly deserve investigation. The correct identification of styles, according to the details provided by al-Qalqashandi and the authors of the albums just mentioned, is particularly important. Such studies should also focus on the presence or the absence of orthoepic signs and decorative elements frequently used by calligraphers in other contexts.

\subsubsection{Internal Features}

The internal features considered by diplomatists relate to the elements of diplomatic discourse (roughly the structure of the contents of the document) and the stylistic and linguistic characteristics of its tenor.

The structure of letters in premodern Islam roughly tallies with the one defined for documents in medieval European diplomatics. The traditional division into three parts (protocol, text, eschatocol), with their internal constituents, are all described by the Mamluk chancery manuals with their own technical terms (fawātih, matn, khawātim). Diplomatists working on Islamic

230 This examination was carried out for the documents held in Florence (see Rizzo, Le Lys et le Lion), Barcelona (forthcoming), and Venice.

231 See Gazagnadou, Remarques; Nielsen, A note.

232 All these features are key to reconstructing the reused documents, as fig. 12.3 in my contribution to this volume shows.

233 The status of the recipient also affected the choice of the reed pen, hence of the calligraphic style.

234 See Blair, Islamic calligraphy; Gacek, Arabic scripts; Atanasiu, De la fréquence des lettres; Atanasiu, Le Phénomène calligraphique.

235 See al-Ṭayyibī, Jāmi maḥāsin kitābat al-kuttāb; Ibn al-Ṣāigh, Tuhfat al-albāb; al-Saḥmāwī, Bị̂̄ā'at al-mujawwad; al-Zaftāwī, Minhāj al-iṣāba. On Ibn al-Ṣā’igh’s treatise, see Jahdani, À propos d'un traité mamelouk. More recently, Juvin has studied the link between epigraphy and calligraphy at the end of the Mamluk period. See Juvin, Recherches. 
chancery documents have tended to use the terms of medieval European diplomatics, though there is no real need to do so, as Dekkiche stresses in her contribution to this volume. It is difficult to change habits.

The various parts of the diplomatic discourse were also affected by the status of the recipient: these parts include the opening formulas, the honorific titles, the taslim (salutatio), and finally, the sultan's signature ('aläma). With regard to diplomatic letters, all these elements have been studied in detail for the Mamluk period. ${ }^{236}$ The honorific titles have also received great attention, particularly from specialists of epigraphy. ${ }^{237}$

Language and style are the most challenging issues for diplomatists working on Mamluk letters because thus far, little work has been carried out on these aspects. Of course, the composition of a letter depended on the status of the addressee, like all the external and other internal elements. Nevertheless, there was another element that secretaries had to take into account: whether he was writing an inceptive letter (ibtid $\vec{a}^{\prime}$ ) or a response. As Gully states, "letters of response were more demanding and more challenging intellectually than the original letters," because "the initiator of the communication (Ar. al-mubtadi') is the arbiter in his letter," while "the respondent is not free to use displacement, rather he is merely the one who follows the [communicative] objective of the initiator, building on his foundation." 238 The munshi', the clerk who drafted the letter, had to display his literary ability by deploying rhetorical devices and textual inspiration from the Arabic literature at his disposal, including Quranic verses, quoted verbatim or loosely (iqtibās); traditions of the Prophet (hadith); poetry; and proverbs. ${ }^{239}$ His style derived from the insh $\bar{a}$, the art of writing letters tailored by generations of belletrists from the early Abbasid period: this art entailed a rhythmic and rhymed prose characterized by hyperbole. ${ }^{240}$ Language and style were of course a question of prestige. For this reason, when a

236 See the second volume of Dekkiche, Le Caire, and her contribution to this volume. On the structure, see also Potthast, Mamlūk diplomatic letters.

237 Max van Berchem was the first to compare honorifics in inscriptions from the Mamluk period with those in the chancery manuals. See, for instance, van Berchem, Matériaux. For honorific titles in general, see al-Bāshā, al-Alqā $b$. For an example of a study of the honorifc titles linked to diplomacy, in this case regarding the Byzantine emperor, see Korobeinikov, Diplomatic correspondence.

238 Gully, The culture 155 . See also my article in this volume.

239 For examples, see Dekkiche, The letter and its response.

240 In general, see al-Musawi, Pre-modern belletristic prose. On the prose of secretaries specifically, see Gully, The culture of letter-writing. An interesting parallel was recently drawn between the European tradition of diplomatic letter-writing from the eleventh century onward and the development of the ars dictaminis. See Grévin, Documents diplomatiques; Grévin, Entre inš $\bar{a}^{\prime}$ et dictamen; Grévin, La Trame et la chaîne. 
letter exposed the negligence of its writer-intentionally or not-, the answer had to match it, though without reproducing the same colloquialisms or stylistic infelicities. ${ }^{241}$ The question was, who was able to decipher these rhetorical devices? The sultans? As already stressed by Vallet, the Mamluk sultans, in contrast to their Rasulid counterparts, had not all mastered Arabic. ${ }^{242}$ The subtleties of Arabic rhetoric, even without considering the textual references, were well beyond them. Clearly, it was the secretaries who were the true interpreters, who valued the artistry of letter-writing and also decoded the other, symbolic, meanings of the letters. ${ }^{243}$

The choice of the language for the issuance of letters on the Mamluk side may seem obvious: Arabic was universally understood in the Muslim world and even beyond, for instance, in Europe, where local translators were available. The secretaries were also the guarantors of the language. However, the situation that prevailed varied according to the period considered. ${ }^{244}$ Yet, the correspondents of the Mamluk sultans were certainly not bound by this rule. The chancery was thus likely to receive missives in Latin, Persian, Turkish, Mongol, or even more exotic languages, and these letters needed to be translated. ${ }^{245}$ But over time, it seems that Arabic lost some of its preeminence as, by the beginning of the tenth/sixteenth century, pieces of correspondence addressed by Qānșawh al-Ghawrī to Selim I were composed in Ottoman Turkish. ${ }^{246}$

241 See Amitai's contribution to this volume.

242 Vallet, Mūsā b. al-Ḥasan al-Mawșilī 133.

243 See Reinfandt's article in this volume. For another category of documents (truces), alQalqashandī stressed that some examples of truces with the crusader states were poorly written, in terms of linguistic quality; this, he wrote, is due to the fact that these documents were prepared by common agreement between the negotiators representing the two parties. Al-Qalqashandī attributed the poor quality of the language in such documents to the negotiators on the crusader side, who used a 'foul' form of Arabic language. He also noted that it was impossible to revise these truces after the issuance of the documents because it would have changed the working of the agreement. See Holt, Early Mamluk diplomacy 7-8.

244 In some cases, it seems that the same letter might have been sent in two languages (Arabic and Turkish). See Favereau's contribution to this volume. According to al-Qalqashandī, Subh al-a'shā vii, 294, letters were addressed in Mongol to the khans of Khwarizm and Qibchaq in the eighth/fourteenth century.

245 For an example of a letter received from Ceylon which could not be translated, see Bauden, Les Relations diplomatiques 11.

246 See Kerslake, The correspondence. The elevation of Persian to the level of lingua franca in the Mongol Empire also had an impact. See Spooner and Hanaway, Literacy; Morgan, Persian as a lingua franca; Hanaway, Secretaries; Mitchell, Safavid imperial tarassul; Mitchell, The practice of politics. Though the Timurids corresponded with the Ottomans in Persian, they did not seem to do the same with the Mamluks, with whom they opted for Arabic in all cases. 
There were two means of validation for diplomatic letters: the signature ('aläma) and the seal impression (tamgha). The most widely used was the first, which was also determined by the status of the addressee, ${ }^{247}$ and could be penned by the sultan or someone else whose role it was, again according to the status of the addressee, as shown by Dekkiche in her contribution to this volume. In the ninth/fifteenth century, al-Sahmāwī reported an evolution that had long been overlooked by diplomatists: the sultan wrote several samples of his different signatures, that varied according to status, in advance of the writing of a given piece of correspondence. The sheets containing these signatures were kept at the chancery and inserted in the rolls, at the right place, when these were prepared for a given recipient. In this volume, Alessandro Rizzo provides evidence of this practice for the first time.

The other means of validation for letters, seals, had a different function. They were applied to the joints of the sheets of the roll to certify that no part of the letter had been replaced. The use of seals by the Mamluk chancery seems to derive from Mongol practice, which in turn was influenced by Chinese chancery rules. ${ }^{248}$ The seals, round or square, were engraved with the titles and name of the reigning sultan and applied using red or gold ink, depending on the status of the addressee. Their usage is not attested in original documents before the end of Mamluk rule, though references in Mamluk sources indicate that they were used as early as the mid-seventh/mid-thirteenth century. 249

Diplomatic letters were complex but essential tools to establish communication with foreign rulers. They were, as Reinfandt states in this volume, an assertion of sovereignty and an emblem of power. Their external and internal features represented a sort of metalanguage that had to be decoded in order to fully grasp their meaning. Thanks to Dekkiche's diachronic analysis in her contribution to this volume, it is possible to better understand this issue. Her analysis also details how the status of a correspondent could change over time. Provided that a large corpus of letters is available from both sides, this diachronic approach, when applied to a specific dynasty, can lead to interesting results that demonstrate the tension generated by the recognition of status by one of the two recipients. ${ }^{250}$ Mamluk letters addressed to foreign rulers

\footnotetext{
247 On the 'alāma in general, see Veselý, Die richterlichen Beglaubigungsmittel.

248 Aigle, Rédaction 15.

249 See al-Ḥalabī, al-Tibyān, fol. $7 \mathrm{~b}$ (square seal, țamgha, of al-Nāṣir Muhammad applied to the joints of a letter dated 723/1323 and addressed to the Rasulid sultan). See also Bauden, Les Relations diplomatiques 9 .

25 See Yüksel Muslu, Attempting to understand; Yüksel Muslu, The Ottomans, as well as
} 
(though not exclusively) had a semiotic value that was widely understood in the Muslim world and beyond. This value has drawn the attention of historians since it was first formulated by John Wansbrough in his Lingua franca. ${ }^{251}$ Additional studies certainly need to be carried out on this aspect of Mamluk letters. Dekkiche's analysis should also be applied to additional sources, in order to refine the framework for interpreting the semiotic value of Mamluk letters. ${ }^{252}$ Her interpretation should be extended to non-Muslim rulers, for which we have original examples that can provide significant clues on the way the Mamluk chancery designated the ranks of non-Muslim rulers and how status evolved over time..$^{253}$

\section{$5 \cdot 3 \quad$ Genesis}

The circumstances and the context in which a document was issued can shed light on the document itself and enable us to better understand it. Medieval European diplomatics has addressed these circumstances for more than a century now, focusing on the actors (mainly the chanceries) and the drafting process. ${ }^{254}$ By contrast, on the Mamluk side, these issues have barely been tackled.

The main actors involved in the diplomatic exchanges were those who worked at the state chancery: the chief secretary who was responsible for reading and decoding the incoming letters, the composition secretary who was charged with drafting inceptive letters and responses, the copyists who prepared the roll that would be delivered to the incoming ambassador or the outgoing Mamluk envoy, and the clerks who registered the document. Despite the richness of the Mamluk narrative and prescriptive sources and the availability of detailed reports and testimonies by European negotiators on the process they went through when interacting with the Mamluk side, there is, as yet,

D'hulster's contribution to this volume. For the Mongols, see Broadbridge, Kingship and ideology.

251 Dekkiche, Reinfandt, and D'hulster engage with this debate in their respective contributions to this volume. See also Niederkorn et al., Diplomatisches Zeremoniell. For Europe, see Le Jan, Les Relations diplomatiques 29.

$25^{2}$ For instance, it seems that the rank of the envoys who were designated to bring these letters to foreign rulers could also have an impact on the format. See Ibn Hijja, Qahwat al-inshä' 125 .

253 Initiating diplomatic relations with the Mamluk sultanate was also challenging for nonMuslim rulers whose chanceries were not always aware of how to address, approach, and deal with the sultan and his chancery. For two examples regarding Savoy and Florence, see Lazzarini, Écrire à l' autre; and Rizzo, Le Lys et le Lion respectively. The contrary was, of course, also true.

254 Guyotjeannin et al., Diplomatique médiévale 223. 
no comprehensive study of the Mamluk chancery. ${ }^{255}$ The category of secretaries has drawn the attention of modern scholars in relation to a variety of issues, such as, who was in charge of the chancery, ${ }^{256}$ what was their social background, who were they related to, ${ }^{257}$ and what sort of education did they have. ${ }^{258}$ But we still lack a study that considers their activities at the chancery. Questions regarding their roles in receiving incoming letters, in deciphering and decoding them, in composing inceptive letters and responses have scarcely been dealt with, and the practicalities of their work has also not been analyzed. ${ }^{259}$ For example, what were the working conditions of the composition secretary?260 Such topics should be at the center of future investigations, in order to improve our appreciation of the activities of those responsible for the issuance of diplomatic letters.

The drafting process, from the initial request to the final registration, is another aspect for which we lack information with regard to the Mamluks. The lack of archives related to the various stages of the drafting of a document (request, composition, control and correction, engrossment, ${ }^{261}$ and finally registration) hinders any attempt to reconstruct the process at play. Fortunately, the narrative and prescriptive sources detail some of these stages. ${ }^{262} \mathrm{~A}$ thorough survey of the literature would definitely help to fill some gaps. ${ }^{263}$

255 The following reference is too concise to fulfill this need: Imamuddin, Diwān [sic] al-inshāa.

256 See Wiet, Les Secrétaires, from the late eighth/fourteenth century until the dawn of the sultanate. The list can be supplemented for the earlier period with the appendices published at the end of al-Mawșilī, al-Burd al-muwashshā 205-307. The editor separated the heads of the chancery from the secretaries in the Ayyubid and Mamluk periods (Egypt and Syria).

257 See Martel-Thoumian, Les Civils; Eychenne, Liens personnels; Gully, The culture of letterwriting, chap. 4.

258 Escovitz, Vocational patterns; Gully, The culture of letter-writing, chap. 5; Van Berkel, A well-mannered man of letters; Van Berkel, Ibn Khaldūn, a critical historian at work; Wiet, Les Classiques. See also, more broadly and on the basis of al-Qalqashandī's Șubḥ al-a'shā, Björkman, Beiträge.

259 See fig. 1.1 for a rare representation of a chancery secretary at work; it faithfully renders his activity and his tools: the pen case, the reed pen and the roll, and the draft. For the pen cases, see Kalus's contribution to this volume. For a depiction of the executive secretary (dawādār, i.e., holder of the pen case), see fig. 1.4.

26o For a rare example in which the composition secretary, Ibn Hijja, explains how he was asked to draft a new letter for the khan of the Golden Horde at the beginning of the ninth/fifteenth century, see Ibn Hijja, Qahwat al-inshä’ 125 .

261 Engrossment refers to the final version of a legal document, especially a deed or statute.

262 For a brief and general presentation of these aspects, see Aigle, Rédaction. For a specific example, we can quote Ibn Hijja, who boasted that he had to compose a letter for the khan of the Golden Horde in one night. Although he was known for "his colossal ego" (Stewart, Ibn Hijjah 142), there must be some element of truth in his testimony.

263 Objects should also be investigated. See fig. 1.2 for a Mamluk case ( $j a c a)$ used as a 
Another very promising research prospect would focus on the interrelationship or the archival bond that ties documents together. ${ }^{264}$ A request made by the representative of a European power, if granted by the sultan, usually initiated a web of documents intended for the foreign ruler and the local administration. ${ }^{265}$

\subsection{Tradition}

From the time of its issuance, an original document could generate various kinds of other documents upstream and downstream. These other witnessesdrafts, copies, translations, editions, commentaries, notes, etc.- - are known as the handwritten and printed tradition of a document. ${ }^{266}$ In diplomatic terms, these documents should be even more thoroughly analyzed, particularly if the original has been lost. The handwritten tradition must be considered from the point of view of the issuer and the recipient.

For the Mamluk chancery, as we have already emphasized, the registers for the archiving of incoming and outgoing letters, if and when they existed, have been completely lost and are only known to have existed thanks to the description given by al-Qalqashandī. ${ }^{267}$ In the absence of material witnesses-not only registers but also original documents bearing registration marks-, the study of the tradition of documents on the Mamluk side is almost impossible. By contrast, the process of translation can be analyzed on the basis of the information found in chancery manuals and narrative sources. For instance, al-Qalqashandī details how letters received in a foreign language like Greek or

container for the delivery of a diplomatic letter. This category of object is not described in the chancery manuals but is attested in narrative sources. See Reinfandt's contribution to this volume for a reference to the object that contained a letter addressed by the Nasrid ruler to the Mamluk sultan.

264 Various categories of documents issued by the Mamluk chancery could be linked to a single document received from a European power (usually a letter). This is defined as the interrelationship of documents, or web.

265 For instance, in 1422, the Venetian embassy led by Bernardo Loredan and Lorenzo Capello generated some twenty documents: one general decree, one letter to the doge, three decrees addressed to the authorities of Alexandria, ten decrees issued for various authorities in Syria, one decree for the governor of Damietta, and four decrees related to the ambassadors' request to make the pilgrimage to the Holy Sepulchre. See Thomas and Predelli, Diplomatarium ii, 320-31. The significance of the question of the interrelationship of documents was assessed by Wansbrough, A Mamlūk commercial treaty. Rizzo has studied this specifically for Florence, Le Lys et le Lion.

266 Guyotjeannin et al., Diplomatique médiévale 271. In what follows, we have left aside the printed tradition for reasons of space.

267 See above. 
Latin were translated at the chancery by a clerk whose role was specifically to interpret these languages, sometimes with the help of a member of the Christian community, like an archbishop. The translated text was then transcribed on a sheet of paper pasted onto the original letter. ${ }^{268}$ Such descriptions are too rare to allow a reconstruction of the full process over the duration of the sultanate. So, while the role of intrepreters and translators at the chancery has been studied by al-Durūbī, our knowledge of their activities, which relies solely on sources and not on documents, remains fragmentary. ${ }^{269}$ We also know that letters issued by the chancery were sometimes translated into the language of the recipient and sent together with the Arabic version. However, there is no indication that this was done for non-Muslim rulers. ${ }^{270}$

If it were not for the European archives, the tradition of Mamluk documents after they were received by their recipients would also be difficult to investigate, though we must be circumspect with our enthusiasm here too. In contrast to documents issued by western Islamic chanceries, where the format allowed interlinear translation and was more easily preserved because they were in a single sheet, Mamluk documents never featured the translation prepared by the European counterpart, either between the lines or on the verso. The translations that have been preserved are usually found in registers, but can rarely be compared with the original in Arabic. Studies on the accuracy of translations carried out from the European side are available for a very limited number of cases, ${ }^{271}$ and more research needs to be done on this topic in order to contend with some idées reçues promoted by nineteenth-century scholars who suspected that inaccuracy was intentional on the European side. ${ }^{272}$ As Wansbrough noted, the discrepancies should be addressed according to the circumstances in which the translations were carried out. When dealing with this issue, we must keep in mind questions such as, "Who commissioned the translation?", "Why was it commissioned?", and "Who undertook the translation?"273

\footnotetext{
268 al-Qalqashandī, Subḥ al-a shā viii, 123.

269 al-Durūbī, Harakat; al-Durūbī, Aṣnāf al-tarājima; al-Durūbī, Muqaddima.

270 See Wansbrough, Documents 20.

271 For the Almohads, the recent work of Buresi is worth mentioning here for its method of analysis: Buresi et al., Les Usages linguistiques; Buresi, Traduttore, traditore. For translations of Mamluk documents addressed to the Crown of Aragon, see Potthast, Translations.

272 See Amari, I diplomi v.

273 See Wansbrough, Documents 19.
} 
In a 2006 article provocatively entitled "Byzantinische Diplomatik: Dead or Alive?," Alexander Beihammer tried to establish that Byzantine diplomatics, despite the results yielded over more than a century, still had a bright future, especially in light of the various 'turns' medieval studies witnessed during the past decades. Diplomatics is among the ancillary sciences, all of which have witnessed a revival of sorts; thus, it may still bring innovative solutions to the analysis of documents, not only by taking advantage of technical innovations now at scholars' disposal, but also by drawing inspiration from the new perspective used by several scholars in the field of historical studies. In general, and despite the differences that characterize the Byzantine and the Mamluk diplomatic traditions, we can draw similar conclusions for Mamluk diplomatics.

Over the century stretching from the mid-nineteenth to the mid-twentieth century, the majority of the documents preserved in archival repositories linked to the diplomatic relations have been identified, catalogued, edited, translated, analyzed, and studied. If there are still a few documents that remain unpublished, the work can be considered, for the most part, complete. Thanks to these publications, historians have gained access to these documents and can use them for the studies they carry out on trade, politics, and diplomacy. The situation thus seems ideal, but is it really? The review of the corpus shows that a majority of the Mamluk documents were published during the embryonic stages of our knowledge and interest in diplomatic issues. During the 1960s, the works of John Wansbrough, who was part of a movement of scholars who were increasingly concerned with such issues and paid more attention to the descriptive and analytic approaches, set new standards. Following in his footsteps, other generations of researchers have made giant strides to improve methods of analyzing documents and adopting those developed in related fields of diplomatics. Nevertheless, the general trend has been to consider the work done by the founding fathers, like Michele Amari, as beyond question. This lack of criticism has meant that the work of generations of historians accepted, at face value, the readings of the editors of documents, without returning to the sources. Fortunately, a few years ago, a new movement was initiated; it aims to revise the work of the predecessors by poring over the originals. It has already yielded unexpected results. ${ }^{274}$ The reappraisal of the documentation from two of the richest archival repositories (Florence

274 See Bauden, Due trattati. 
and Barcelona) is well underway and will soon appear in print, thus offering new editions accompanied by a true diplomatic commentary based on all the sources available, together with reproductions of the full corpus. ${ }^{275}$ The latter element is particularly significant, as it is the only way to render the semiotic value of the documents; this aspect is also instrumental for anyone interested in grasping their performative role. The detailed description of all the physical features of the documents will contribute to enhance our knowledge of Mamluk diplomatics. By analyzing these attributes, we can focus on issues like the sizes of paper, a subject that has been studied over the last two decades, but one that definitely still merits further investigation.

We must also spare no effort in reassessing the documents held in other repositories. The survey at the end of this state of research should serve as a starting point for a census of all the documents related to diplomatic exchanges with the Mamluks and preserved in archives, though it should not be seen as definitive. As I have noted, the inspection of the archives can still bring delightful surprises: the identification of thus far unknown fragments of documents surfacing, as in the cases of Barcelona and Florence, are evidence of this. The perusal of registers could also yield additional translations and copies of documents addressed to the Mamluk sultanate. The publication of those categories of documents (translations and copies) in conjunction with the original documents, if any, to which they are linked should also be encouraged. This allinclusive approach is not only necessary for our understanding of the whole corpus, like the interrelationship or the bond of documents, but it also provides other opportunities to delve deeper into the matter of the translation process and the issues it raises.

In addition to the archival documents, we must also focus our attention on the prescriptive and descriptive sources, the chancery manuals/formularies and the collections of models respectively. While diplomatists have enjoyed access to critical editions of the most instrumental chancery manuals and formularies, this enviable situation has led to a sort of disinterest in unpublished texts pertaining to this category. Some of these texts certainly deserve to be published, studied, and compared with those that have been accessible for decades. A publication program for these sources should be set up in the future. The same is true for the collections of letters. Despite the recent interest focused on Ms Arabe 4440, the collection remains largely unpublished. An unknown copy of the same text identified in Algiers should facilitate its edition. The other collections, those produced by Mamluk secretaries or by

275 For Florence, see Rizzo, Le Lys et le Lion, vols. 2 and 3, as well as his forthcoming publication of both volumes. The project for Barcelona is well underway. 
secretaries active in the chanceries of rulers addressed by the Mamluks, are also deserving of attention. Given the value of these copies preserved in the collections of letters, the census discussed here must include them, in addition to those found in the chancery manuals and the formularies because they provide details of the physical features (the format of the roll, the presence and location of signature, the color of the ink, etc.) significant for diplomatics. Our understanding of the rules applied by the Mamluk chancery for the issuance of diplomatic letters can only be improved when additional sources-originals and translations, as well as the copies in prescriptive and descriptive sourcescovering the duration of the Mamluk sultanate are taken into consideration. The relative material provided by the other chancery traditions should not be neglected because our interpretation of the semiotic value of the letters with their common-Wansbrough's lingua franca — or unique symbols, can only be achieved through a comparative approach.

Should the copies that contemporary or later historians transmitted in their chronicles be included in such a census? In the strictest terms of diplomatics, these copies are more problematic because, first, their authenticity is hard to assess, and second, it is difficult to verify the soundness of the text quoted. Nevertheless, with these caveats in mind, these copies could still be listed in the census, provided their origin is clearly indicated. In such cases, the numerous chronicles that have survived for the Mamluk period, those edited or still unpublished, as well as those composed in other regions of the Islamic world, would enrich the collection of documents in significant numbers, which could then be critically assessed on the basis of the various preserved versions of a single text. Yet, the narrative sources are also instrumental to our understanding of the functioning of the chancery, as these complement the data supplied by the chancery manuals. A study of the practices of those working for the chancery cannot be written from the unique point of view given by the chancery manuals.

The tools that have been developed and made available to various fields in the humanities must not be overlooked. Tools for textual analysis, for instance, should be used to collect data in the documents for a wide gamut of analyses: rhetorical devices, quotations (Quran, traditions of the Prophet, poetry, prose), and the order and proximity of epithets are just a few of the issues that could be dealt with in such a framework. The same methods could be carried out on the translations in order to understand if specific patterns can be identified for the same target language and beyond. In the same vein, the digital reproductions, which are easier to produce nowadays, can stimulate debate on the semiotics of documents, an element that could scarcely be considered just a few years ago. 
In order to use such tools though, we must rethink the way documents are published. We certainly cannot replace the printed form, which has been privileged so far for the editing of documents, but we can supplement it with digital editions. Ideally, the text of the documents should be available in a way that renders the physical appearance of the text (the size of the characters, layout, position of parts of the text) with hyperlinks to the digital images. The Text Encoding Initiative (TEI) and Extensive Markup Language (XML) are both tools that would help to represent these features in an ideal way. The above-mentioned census for the Mamluk period could thus be extended into a database that would consider all the possible forms of a document (originals, copies, translations), without being limited to one language. ${ }^{276}$

This broad outline shows what still needs to be accomplished before we are able to publish a manual of Mamluk diplomatics, even one limited to documents on diplomatic relations. If it is prepared on the basis of the present state of research, such a manual would only be a sketch of rules largely derived from the published prescriptive sources. This would mean neglecting the fact that diplomatics is defined by the documents themselves rather than by manuals written by secretaries. Of course both are intimately connected, but should not be considered exclusively and independently from each other. The research program drawn up in these pages will certainly contribute to reach that goal.

276 There are some restrictions to such existing databases. Asnad (http://www.asnad.org/en/) is a digital Persian archive and presents itself as an image database of historical Persian documents from Iran and Central Asia up to the twentieth century. It covers both public and private documents exclusively composed in Persian. The Arabic Papyrological Database (APD) (http://www.apd.gwi.uni-muenchen.de:808o/apd/project.jsp), which is not an image database, was created to collect the text and the metadata of documents written on papyrus, parchment, and paper exclusively in Arabic. The chronological range stretches from the beginning of Islam until the Ottoman conquest of Syria and Egypt in the early sixteenth century. The argument for the upper chronological limit is that archives have been preserved for the Ottoman dynasty. However, the project does not take into consideration all the categories of Arabic documents, like waqf documents, which are excluded because they are "especially numerous in Egypt for the Mamluk period onwards and often fall between the documentary and literary [sic] genre" (http://www.naher-osten .uni-muenchen.de/isap/isap_checklist/index.html; consulted in March 2017). The issue of quantity thus seems to be prevalent here. And, only originals are taken into account. As for the literary genre, it goes without saying that diplomatic letters, as seen in the previous pages, can certainly be described as perfect examples of the literary production of secretaries who defined themselves as belletrists and were proud of their output. But according to the criteria set for the APD, they would be excluded from the database. 


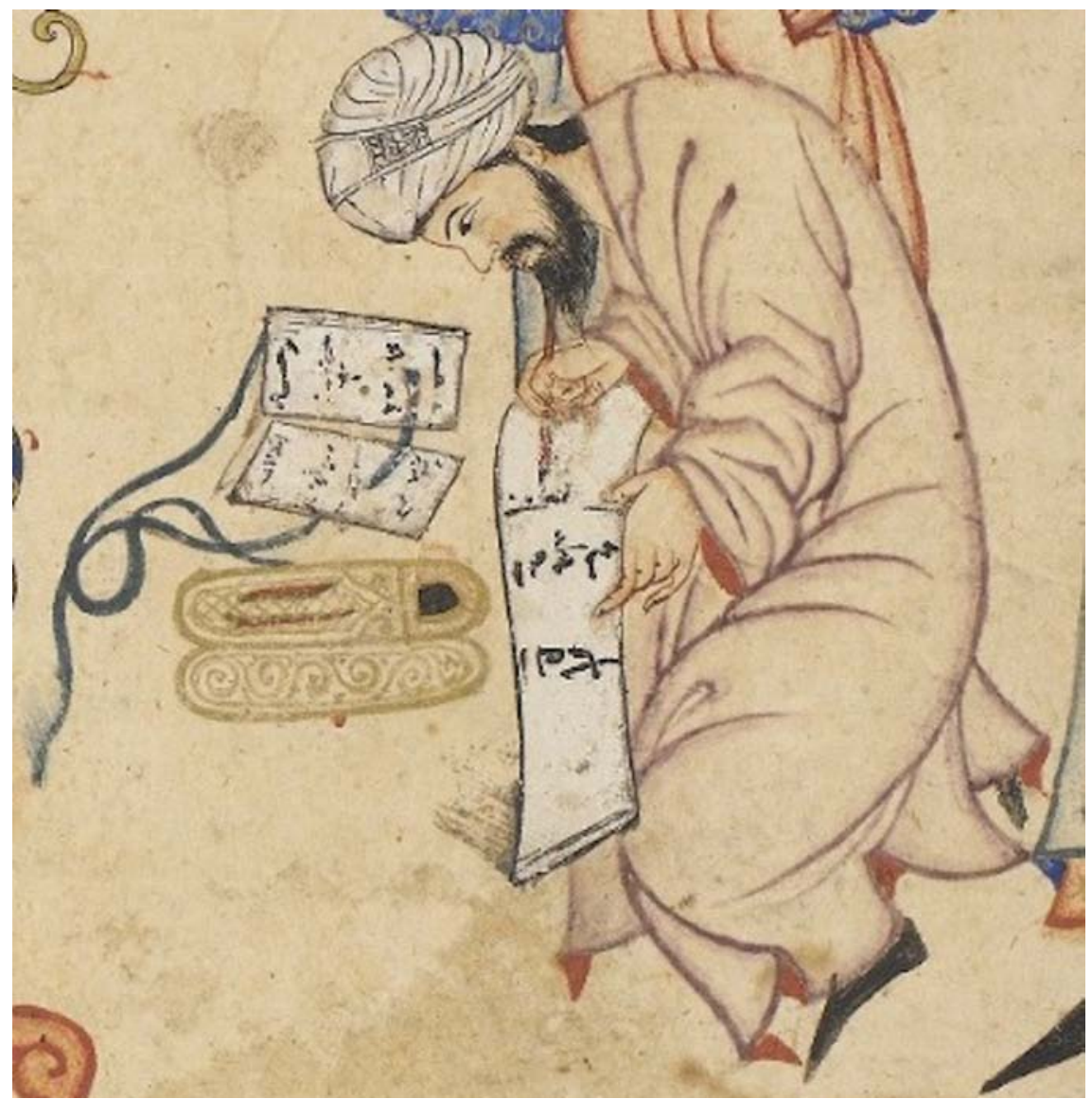

FIGURE 1.1 A secretary writing a letter COURTESY EDINBURGH UNIVERSITY LIBRARY, MS OR. 20, FOL. 139B 


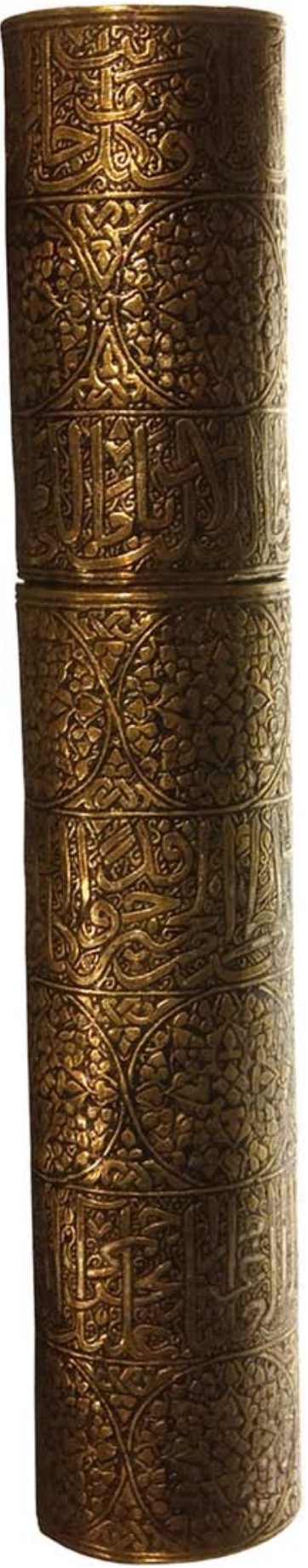

FIGURE 1.2

Case for document (Egypt or Syria, ninth/fifteenth c.) COURTESY OF MUSÉE DU LOUVRE, PARIS, NO. AD 5598

For use by the Author only | (C) 2019 Koninklijke Brill NV 


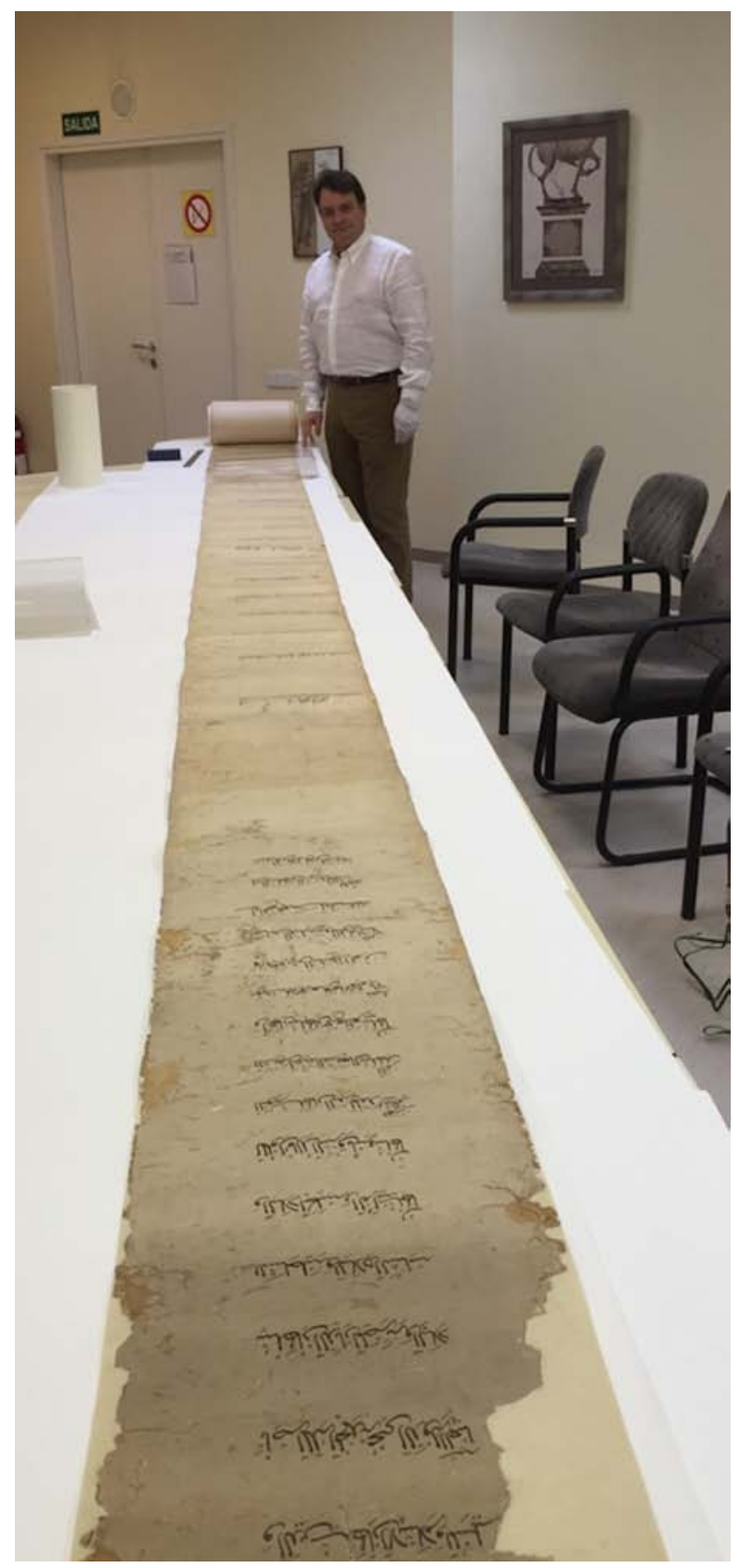

FIGURE 1.3 al-Nāṣir Muhammad's 705/1306 letter to the king of Aragon, James II COURTESY ARCHIVO DE LA CORONA DE ARAGÓN, BARCELONA, CARTAS ÁRABES, DOC. 148 


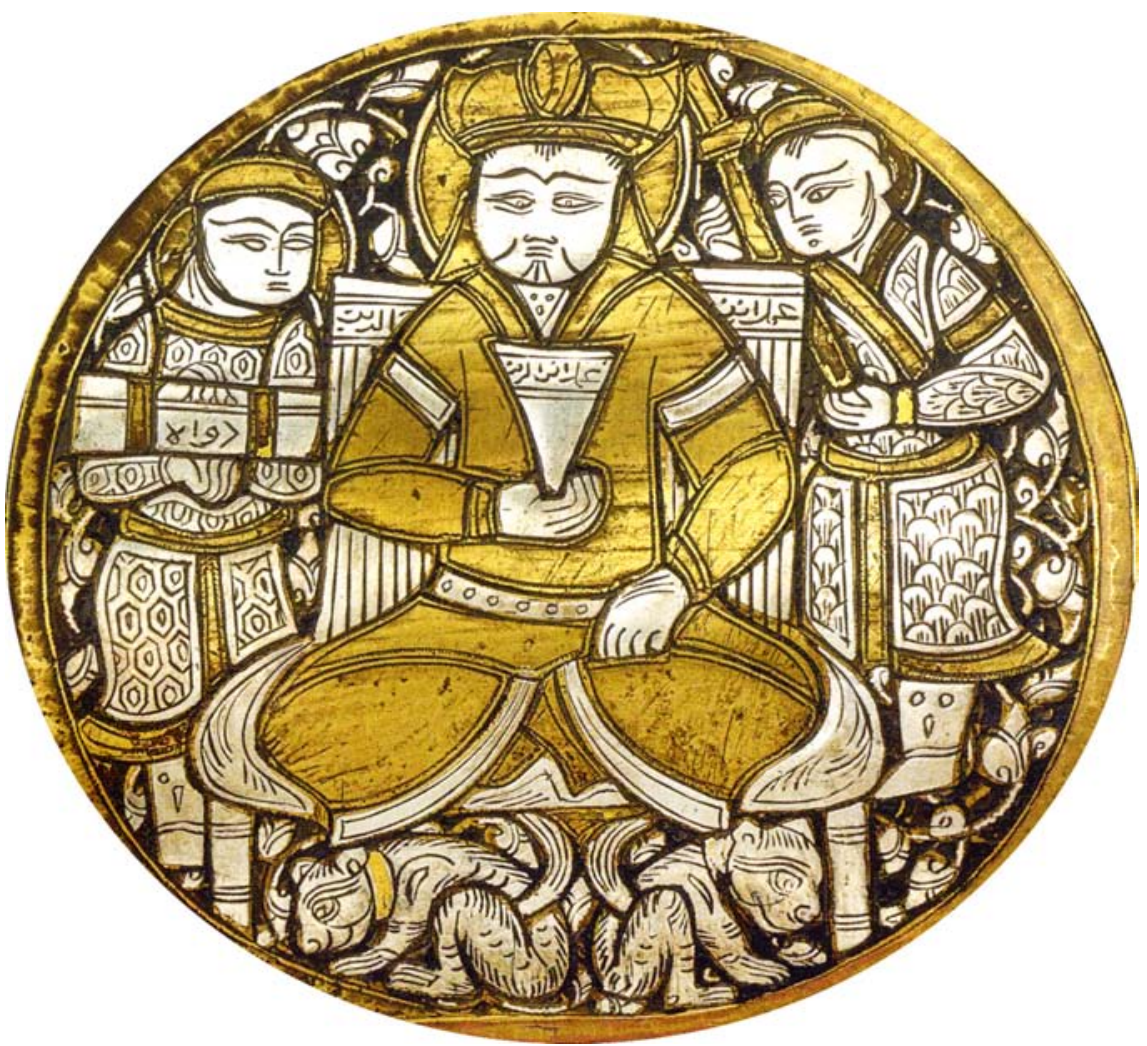

FIGURE 1.4 The executive secretary (dawādār) standing to the left of the sultan and holding the pen case (dawāt) (basin known as St. Louis Baptistry, Syria, first half of eighth/fourteenth c.)

COURTESY MUSÉE DU LOUVRE, PARIS, NO. LP 16 


\section{Appendix: Survey of Documents (Originals and/or Copies) Related to the Diplomatic Relations by and with the Mamluk Sultanate and Preserved in Archival Repositories}

This survey, the first of its kind for the Mamluk period,277 lists documents related to diplomacy (truces, treaties, letters, lists of gifts, decrees, safe-conducts, petitions, instructions to envoys, etc.) that were issued by the respective chanceries. The documents are organized according to the powers with whom the Mamluk sultanate had diplomatic exchanges and for which documents have been preserved in archival repositories, in order of the decreasing number of original Mamluk documents still held. Clearly, with the exception of the Ottomans, this means that this survey is largely concerned with European powers. We can also state with little doubt that it is far from exhaustive. On one hand, as we have seen, previously unknown documents may still be discovered in the European archives and libraries. On the other hand, copies of documents in chancery manuals, collections of letters, anthologies, and historical works may be added for the powers listed here, as well as for several others for which no archives have survived. A project that aims at gathering all the documents, preserved in archives or in sources, related to diplomacy for the Mamluk sultanate would certainly be a major addition to the study of diplomatics and diplomacy.

For each power, the documents are chronologically arranged into subcategories (original documents, then translations for the Mamluk side, copies for the foreign side). For each document, we provide references for the edition or, if unpublished, we cite its shelf number in the archives.

\subsection{Aragon \\ 7.1.1 Mamluk Documents \\ 7.1.1.1 OriginalDocuments}

1. Truce concluded between al-Ashraf Khalīl (r. 689-93/1290-3) and James II (r. 1285-1327) dated 19 Ṣafar 692/29 January 1293: Amari, Trattato stipolato; Alarcón y Santón/García de Linares, Los Documentos $335^{-8}$ (no. 145). ${ }^{278}$

277 If one excepts Roemer, Arabische Herrscherurkunden 337-41, but Roemer only listed Arabic original documents and he also took into account documents issued for Christian communities who were under Mamluk authority (Jerusalem, Sinai). The following reference is mentioned here for the sake of completeness, but it does little to address the issue: Darrāj, Les Documents arabes.

278 Both references reproduce the copy of the truce given by al-Qalqashandī, Șubh al-ash $\bar{a}$ xiv, $63-70$, not the original document mentioned here. 
2. Letter of al-Nāșir Muḥammad (r. 693-4/1293-4, 698-708/1299-13o9, 709-41/1310-41) to James II dated 5 Rajab 699/28 March 1300: Atiya, Egypt and Aragon 17-9 (excerpts only); Alarcón y Santón/García de Linares, Los Documentos 344-6 (no. 146); Holt, al-Nāṣir Muhammad's letter; Bauden, Lists of gifts (doc. 1: list of gifts only).

3. Letter of al-Nāṣir Muhammad to James II dated 13 Shawwāl 703/14 February 1304: Atiya, Egypt and Aragon 22-4 (excerpts only); Alarcón y Santón/García de Linares, Los Documentos 350-1 (no. 147).

4. Letter of al-Nāṣir Muhammad to James II dated 1 Sha'bān 705/16 February 13o6: Alarcón y Santón/García de Linares, Los Documentos 355-6 (no. 148).

5. $\quad$ List of gifts sent by al-Nāșir Muhammad to James II dated the first ten days of Sha'bān 705/16-25 February 1306: Atiya, Egypt and Aragon 2932; Bauden, Lists of gifts (doc. 2).

6. Letter of al-Nāșir Muhammad to James II dated 1o Dhū l-Hijja 714/17 March 1315: Atiya, Egypt and Aragon 36-41; Alarcón y Santón/García de Linares, Los Documentos 36o-2 (no. 149); Bauden, Lists of gifts (doc. 3: list of gifts only).

7. Letter of al-Nāṣir Muḥammad to James II dated 15 Ṣafar 723/23 February 1323: Atiya, Egypt and Aragon 47-52; Alarcón y Santón/García de Linares, Los Documentos 365-6 (no. 15o).

8. Letter of al-Nāșir Muhammad to Alphonso IV (r. 1327-36) dated 15 Jumādā I 728/29 March 1328: Atiya, Egypt and Aragon 57-6o; Alarcón y Santón/García de Linares, Los Documentos 368-9 (no. 151).

9. Letter of al-Nāṣir Muhammad to Alphonso IV dated 1 Jumādā I 730/20 February 1330: Atiya, Egypt and Aragon 62-4 (excerpts only); Alarcón y Santón/García de Linares, Los Documentos 370 (no. 152).

10. Draft of treaty between al-Ashraf Barsbāy (r. 825-41/1422-38) and Alphonso V (r. 1416-58) dated 7 Ramaḍān 833/30 May 1430 (linked to no. 11): Ruiz Orsatti, Tratado; Alarcón y Santón/García de Linares, Los Documentos 372-7 (no. 153); Makkī, Mu'āhada 54-9.

11. Decree issued by al-Ashraf Barsbāy regarding the Catalan merchants dated 3 Dhū l-Qa'da 833/24July 1430 (linked to no. 10):Viladrich, Jaque al Sultán; Viladrich, Solving (partial edition).

\subsubsection{Translations}

12. Truce concluded between al-Ashraf Khalī (r. 689-93/129o-3) and James II (r. 1285-1327) dated 19 Ṣafar 692/29 January 1293 (see no. 1): Masiá de Ros, La Corona de Aragón 266-70 (no. 3).

13. Letter of al-Nāṣir Muhammad to James II dated 14 Ṣafar 719/6 April 1319: Masiá de Ros, La Corona de Aragón 314-5 (no. 42). 
14. Letter of al-Nāṣir Muhammad to James II dated 31 March 1322: Masiá de Ros, La Corona de Aragón 329-30 (no. 54).

15. Letter of al-Nāṣir Muhammad to Alphonso IV dated 15 Jumādā I 728/29 March 1328 (see no. 8): unpublished (preserved with the original, under shelf mark no. 151).

16. Letter of al-Nāṣir Muḥammad to Alphonso IV dated 1 Jumādā I 73o/20 February 1330 (see no. 9): unpublished (preserved with the original, under shelf mark no. 152).

17. Letter of al-Ashraf Sha'bān (r. 764-78/1363-77) to Peter IV (r. 1336-87) dated 16 Rajab 775/1 January 1374:279 López de Meneses, Pedro IV 317-8; López de Meneses, Pedro el Ceremonosio 356-7 (no. XXVIII).

18. Letter of the atābak Barqūq to Peter IV dated 21 Rajab 784/30 September 1382: López de Ayala, Crónica 81-3.

19. Letter of al-Mu'ayyad Shaykh (r. 815-24/1412-21) addressed to the city of Barcelona datable to 816-7/1414: de Capmany y Palau, Memorias ii, 419 (no. 283).

20. Letter of al-Zāhir Jaqmaq (r. 842-57/1438-53) to the city of Barcelona dated 29 Shawwāl 842 (?)/14 April 1439: de Capmany y Palau, Memorias ii, 463 (no. 316$){ }^{280}$

\subsubsection{Aragonese Documents}

21. Letter of James II to al-Ashraf Khalīl dated 10 August 1292: de Capmany y Palau, Memorias ii, 78-8o (no. 53); Masiá de Ros, La Corona de Aragón 264-6 (no. 2).

22. Letter of James II to al-Nāṣir Muhammad dated 1 June 1303: Golubovich, Biblioteca iii, 75-6; Atiya, Egypt and Aragon 20-1; Masiá de Ros, La Corona de Aragón 290 (no. 25).

23. Letter of James II to al-Nāṣir Muḥammad dated 1 September 1305: Golubovich, Biblioteca iii, 77-9; Atiya, Egypt and Aragon 26-7; Masiá de Ros, La Corona de Aragón 292-3 (no. 28).

24. Letter of James II to al-Nāṣir Muhammad dated 18 November 1307: Masiá de Ros, La Corona de Aragón 300-1 (no. 33).

279 In the translation, the month is given as maçat. This letter is an answer to the embassy sent by Peter IV in October 1373 (see no. 41), therefore the month is tentatively read Rajab, which is the closest term to the form given in the Catalan version.

280 This author reads the year as 840 , though Jaqmaq, the sultan who issued the letter, began

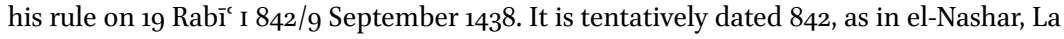
Lettre. In his study of the letter, el-Nashar incorrectly states that it is in Arabic. 
25. Letter of James II to al-Nāṣir Muhammad dated 10 June 13og: Masiá de Ros, La Corona de Aragón 302-3 (no. 35).

26. Letter of James II to al-Nāṣir Muhammad dated 8 September 1314: de Capmany y Palau, Memorias ii, 132-3 (no. 9o); Finke, Acta aragonensia ii, 751-2 (no. 467: excerpts only); Masiá de Ros, La Corona de Aragón 304-7 (no. 37).

27. Letter of James II to al-Nāșir Muhammad dated 27 August 1318: Finke, Acta aragonensia ii, $75^{2}$ (no. 467: excerpts only); Golubovich, Biblioteca iii, 187 (summary only); Masiá de Ros, La Corona de Aragón 311-3 (no. 41).

28. Letter of James II to al-Nāṣir Muhammad dated 23 December 1320: Masiá de Ros, La Corona de Aragón 315-6 (no. 43).

29. Letter of James II to al-Nāșir Muhammad dated 11 September 1322: de Capmany y Palau, Memorias ii, 161 (no. 109); Finke, Acta Aragonensia ii, 755-6 (no. 470); Golubovich, Biblioteca iii, 233-4; Atiya, Egypt and Aragon 45 (excerpts only); Masiá de Ros, La Corona de Aragón 322-5 (no. 51).

30. Instructions delivered to the ambassadors sent to al-Nāṣir Muhammad datable to September 1322: Masiá de Ros, La Corona de Aragón 324-5 (no. 51).

31. Letter of James II to al-Nāṣir Muhammad dated 3 July 1327: Masiá de Ros, La Corona de Aragón 332 (no. 57).

32. Letter of James II to al-Nāșir Muhammad dated 20 August 1327: Finke, Acta Aragonensia ii, 758-9 (no. 472); Golubovich, Biblioteca iii, 312-4; Atiya, Egypt and Aragon 53-5 (excerpts only); Masiá de Ros, La Corona de Aragón 334 (no. 59).

33. Letter of Alphonso IV to al-Nāṣir Muhammad dated 1 July 1329: Masiá de Ros, La Corona de Aragón 336-7 (no. 61).

34. Instructions delivered to the ambassadors sent to al-Nāṣir Muhammad datable to June-July 1329: Masiá de Ros, La Corona de Aragón 337-8 (no. 61).

35. Letter of Alphonso IV to al-Nāṣir Muhammad dated 15 August 1329: Masiá de Ros, La Corona de Aragón 341 (no. 65).

36. Instructions delivered to the ambassadors sent to al-Nāṣir Muhammad dated 15 August 1329: Masiá de Ros, La Corona de Aragón 341-2 (no. 65).

37. Letter of Alphonso IV to al-Nāṣir Muhammad dated 31 August 1329: Masiá de Ros, La Corona de Aragón 342 (no. 66).

38. Letter of Alphonso IV to al-Nāṣir Muhammad dated 15 September 1333: Masiá de Ros, La Corona de Aragón 346-7 (no. 71).

39. Letter of Peter IV to al-Kāmil Sha'bān (r. 746-7/1345-6) dated 1 Decem- 
ber 1345: López de Meneses, Florilegio 183-5 (no. XIV); López de Meneses, Pedro el Ceremonosio 336-7 (no. v).

4O-1. Two letters of Peter IV to al-Kāmil Sha'bān dated 15 September 1346: López de Meneses, Correspondencia 294-5, 296; López de Meneses, Pedro el Ceremonosio 337-8 (no. vi).

42. Letter of Peter IV to al-Ṣâliḥ Ṣāliḥ (r. 752-5/1351-4) dated 4 April 1353:281 López de Meneses, Correspondencia 297; López de Meneses, Pedro el Ceremonosio 339-40 (no. IX).

43. Letter of Peter IV to al-Ṣāliḥ Ṣaliḥ dated 13 June 1354: López de Meneses, Correspondencia $298-9$.

44. Instructions delivered to the ambassador sent to al-Nāșir Ḥasan (r. 74852/1347-51; 755-62/1354-61) datable to September 1356: Vincke, Die Gesandtschaften 120 (n. 23); Vincke, Pedro el Ceremonosio 18 (excerpts only).

45. Letter of Peter IV to al-Nāșir Hasan dated 17 September 1356: López de Meneses, Correspondencia 300-1; López de Meneses, Pedro el Ceremonosio 345 (no. XVI).

46. Letter of Peter IV to al-Nāṣir Ḥasan dated 23 January 1361: Vincke, Pedro IV 4-5.

47. Letter of Peter IV to (r. 762-4/1361-3) dated 12 October 1361: López de Meneses, Correspondencia 302.

48. Letter of Peter IV to al-Manșūr Muhammad dated 26 December 1362: López de Meneses, Correspondencia 303-4; López de Meneses, Los consulados 138-40 (no. IV); Golubovich, Biblioteca iv, 410-1.

49. Letter of Peter IV to the governor of Alexandria dated 11 September 1364: López de Meneses, Correspondencia 305.

50. Letter of Peter IV to al-Ashraf Sha'bān dated 28 March 1366: López de Meneses, Correspondencia 306.

51-2. Two letters of Peter IV to al-Ashraf Sha'bān dated 20 June 1366: López de Meneses, Correspondencia 307-9, 310-1.

53. Instructions delivered to the ambassadors sent to al-Ashraf Sha'bān datable to June 1366: López de Meneses, Los consulados 141-3 (no. VI); López de Meneses, Pedro el Ceremonosio 321 (excerpt only).

54. Letter of Peter IV to al-Ashraf Sha'bān dated 4 December 1368: López de Meneses, Correspondencia 312.

55. Letter of Peter IV to al-Ashraf Sha'bān dated 3 October 1370: López de Meneses, Correspondencia $313-5$.

281 The letter is addressed to al-Nāṣir Ḥasan, though he had been replaced by one of his brothers for the previous two years. 
56. Letter of Peter IV to a high amir of al-Ashraf Shacbān dated 8 October 1373: López de Meneses, Correspondencia 316; López de Meneses, Pedro el Ceremonosio $35^{2}$ (no. Xxv).

57. Instructions delivered to the ambassador sent to al-Ashraf Sha'bān dated 9 October 1373: López de Meneses, Pedro el Ceremonosio 3535 (no. XXVI).

58. Letter of Peter IV to al-Ashraf Sha'bān dated 1o October 1373: López de Meneses, Correspondencia 316-7; López de Meneses, Pedro el Ceremonosio $355^{-6}$ (no. XXVII).

59. Letter of Peter IV to al-Manșūr 'Alī (r. $77^{8-83 / 1377-82)}$ ) dated 24 November 1377: López de Meneses, Correspondencia 320-1.

6o. Instructions delivered to the ambassador sent to al-Manșūr 'Alì dated June 1379: López de Meneses, Los consulados 147-9 (no. X).

61-2. Two letters of Peter IV to al-Manșūr 'Alī dated 17 June 1379: López de Meneses, Los consulados 149-50 (no. XI: the first letter only); López de Meneses, Correspondencia 322-3.

63. Letter of Peter IV to al-Manșūr 'Alī dated 1 June 1380: López de Meneses, Correspondencia 324 .

64. Letter of Peter IV to the atābak Barqūq dated 1 June 1380: López de Meneses, Correspondencia 324-5.

65. Letter of Peter IV to al-Manșūr 'Alī dated 3 September 1380: de Bofarull y Mascaré, Colección vi, 370-2 (no. CXviI); de Mas Latrie, Histoire iii, 759-6o.

66. Letter of Peter IV to the governor of Alexandria dated 3 October 1380: de Bofarull y Mascaré, Colección vi, 372-4 (no. CXVIII).

67. Letter of Peter IV to al-Ṣâliḥ Ḥājjì (r. 783-4/1381-2) dated 3 May 1382: Rubió y Lluch, Diplomatari 561 (no. DIX).

68. Letter of Peter IV to the governor of Alexandria dated 3 May 1382: Rubió y Lluch, Diplomatari 562 (no. Dx).

69. Letter of Peter IV to al-Ẓāhir Barqūq (r. 784-91/1382-89; 792-8o1/139o9) datable to June 1383: López de Meneses, Correspondencia 328.

70. Letter of Peter IV to al-Ẓāhir Barqūq dated 1 June 1384: López de Meneses, Los consulados 152 (no. XIV); López de Meneses, Correspondencia 329 .

71. Letter of Peter IV to the caliph and the supreme judges of Cairo dated 1 June 1384: López de Meneses, Los consulados 153 (no. XV); López de Meneses, Correspondencia $329-30 .{ }^{282}$

282 A similar letter was addressed to the supreme judges of Alexandria, but it was not copied into the registers. López de Meneses, Correspondencia 329-30. 
72. Letter of Peter IV to the governor of Alexandria dated 21 June 1384: López de Meneses, Los consulados 154 (no. XVII); López de Meneses, Correspondencia 33 .

73. Letter of Peter IV to al-Zāhir Barqūq dated 13 October 1384: López de Meneses, Los consulados 155 (no. XVIII); López de Meneses, Correspondencia 331-2.

74. Letter of Peter IV to the supreme judge of Cairo dated 13 October 1384: López de Meneses, Los consulados 156 (no. XIX); López de Meneses, Correspondencia $332 .{ }^{283}$

75. Letter of Peter IV to al-Zāhir Barqūq dated 30June 1385: López de Meneses, Correspondencia 333 .

76. Letter of Peter IV to al-Zāhir Barqūq dated 2o November 1385: López de Meneses, Correspondencia 334 .

77. Letter of Peter IV to the Mālikī judge in Cairo dated 20 November 1385: López de Meneses, Los consulados 159 (no. XXIII); López de Meneses Correspondencia $334-5$.

78. Letter of Peter IV to the chamberlain in Cairo dated 20 November 1385: López de Meneses, Los consulados 159 (no. XXIV); López de Meneses Correspondencia 335 .

79. Letter of Peter IV to the governor of Damascus dated 20 November 1385: López de Meneses, Los consulados 158 (no. XXII).

8o. Letter of Peter IV to al-Ẓāhir Barqūq dated 6 January 1386: López de Meneses, Los consulados 160-1 (no. Xxv); López de Meneses, Correspondencia $33^{6-7}$.

81. Letter of Peter IV to al-Ẓāhir Barqūq dated 11 May 1386: López de Meneses, Los consulados 165 (no. Xxx).

82. Instructions delivered to the ambassador sent to al-Zāhir Barqūq dated May 1386: López de Meneses, Los consulados 166-8 (no. XXXII).

83. Letter of John I (r. 1387-97) to the governor, the chamberlain, and various other officials in Damascus and Beirut dated 2 October 1392: López de Meneses, Los consulados 171-2 (no. XXXvi).

84. Letter of Martin I (r. 1396-1410) to the governor of Damascus or his lieutenant dated 14June 1397: López de Meneses, Los consulados 175-6 (no. XXXVIII).

85. Letter of Martin I to al-Z̄āhir Barqūq dated 18 September 1398: López de Meneses, Los consulados 176-7 (no. XxxIX).

283 Three similar letters were sent to the governor of Alexandria, the chamberlain, and the secretary of the chancery. It was not copied into the registers. Ibid. 
86. Letter of Martin I to al-Zāhir Barqūq dated 17 September 1399: Golubovich, Biblioteca v, 329; López de Meneses, Pedro el Ceremonosio 327 (excerpt only).

87. Letter addressed to the authorities of Alexandria dated 7 October 1459: de Capmany y Palau, Memorias ii, 559 (no. 382).

88. Letter addressed to al-Ashraf Īnāl (r. 857-65/1453-61) dated 24 July 1460: de Capmany y Palau, Memorias ii, 568 (no. 385).

89. Letter addressed to al-Ashraf Qāytbāy (r. 872-901/1468-96) dated 10 May 1486: de Capmany y Palau, Memorias ii, 597 (no. 409).

9o. Letter of credentials for the Catalan consul addressed to al-Nāṣir Muhammad b. Qāytbāy (r. 9o1-4/1496-8) dated 15 October 1498: de Capmany y Palau, Memorias ii, 623 (no. 427).

91. Letter of credentials for the Catalan consul addressed to al-Ashraf Qānșawh al-Ghawrī (r. 9o6-22/15o1-16) and dated 2 June 15o8: de Capmany y Palau, Memorias ii, 633 (no. 436).

\subsection{Florence}

7.2.1 Mamluk Documents

7.2.1.1 Original Documents

1. Letter of al-Ashraf Barsbāy to the Florentine authorities dated 5 Shawwāl 825/22 September 1422: Amari, I diplomi 165-8 (no. XXXVII of the prima serie); Rizzo, Le Lys et le Lion ii, 19-39.

2. Decree issued by al-Ashraf Qāytbāy and addressed to the authorities of the sultanate dated 6 Dhū l-Hijja 894/31 October 1489:284 Wansbrough, A Mamlūk commercial treaty $5^{2-70}$; Rizzo, Le Lys et le Lion ii, $5^{1-95}$.

3. Letter of al-Ashraf Qāytbāy to Lorenzo de' Medici (r. 1469-92) dated 24 Dhū l-Hijja 894/18 November 1489: Amari, I diplomi 181-3 (no. XXXIX of the prima serie); Rizzo, Le Lys et le Lion ii, 41-50.

4. Letter of al-Nāṣir Muhammad b. Qāytbāy to the governor of Damascus dated 25 Jumādā I 902/29 January 1497: Wansbrough, Venice and Florence 497-523; Rizzo, Le Lys et le Lion ii, 97-153.

5. Letter of al-Nāșir Muhammad b. Qāytbāy to the governor of Alexandria dated 7 Jumādā II 9o2/10 February 1497: Amari, I diplomi 184-209 (no. XL of the prima serie); Rizzo, Le Lys et le Lion ii, 155-208.

284 There is an eighteenth-century Arabic copy of this document together with an Italian translation (different than doc. no. 16) in MS 50 (Florence, National Library, Fondo del Furia, fols. 1a-18a). See Wansbrough, A Mamlūk commercial treaty 5o (no. H). 
6. Letter of al-Nāṣir Muhammad b. Qāytbāy to the authorities of Florence dated 10 Jumādā II 902/13 February 1497: Amari, I diplomi 210-3 (no. XLI of the prima serie); Rizzo, Le Lys et le Lion ii, 209-18.

7. Decree issued by Qānșawh al-Ghawrī and addressed to the authorities of the sultanate dated 18 Dhū l-Qadda 911/12 April 15o6: Amari, I diplomi 214-7 (no. XLII of the prima serie); Rizzo, Le Lys et le Lion ii, 219-29.

8. Decree issued by Qānșawh al-Ghawrī and addressed to the authorities of Florence dated 12 Jumādā II 913/19 October 1507: Amari, I diplomi 218-20 (no. XLIII of the prima serie); Rizzo, Le Lys et le Lion ii, 231-39.

9. Decree issued by Qānșawh al-Ghawrī and addressed to the authorities

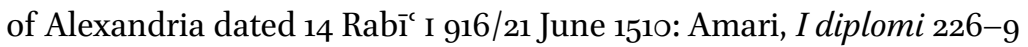
(no. XLV of the prima serie); Rizzo, Le Lys et le Lion ii, 241-50.

10. Letter of Qannșawh al-Ghawrī to the authorities of Florence dated 14 Rabī' I 916/21 June 1510: Amari, I diplomi 221-5 (no. XLIV of the prima serie); Rizzo, Le Lys et le Lion ii, 251-63.

\subsubsection{Translations}

11. Letter of al-Ashraf Barsbāy to the authorities of Florence dated 5 Shawwāl 825/22 September 1422 (see no. 1): Amari, I diplomi 336-7 (no. XXXVIII of the seconda serie); Rizzo, Le Lys et le Lion ii, 275-6.

12. Decree issued by al-Ashraf Barsbāy to the authorities of Florence dated 5 Shawwāl 825/22 September 1422: Amari, I diplomi 338-40 (no. XXXIX of the seconda serie); Rizzo, Le Lys et le Lion ii, 277-9.

13. Decree issued by al-Ashraf Barsbāy and addressed to the authorities of Alexandria dated 8 Shawwāl 825/25 September 1422: Amari, I diplomi 341-3 (no. XL of the seconda serie); Rizzo, Le Lys et le Lion ii, 281-4.

14. Letter of al-Ashraf Qāytbāy to Lorenzo de' Medici dated 16 Dhū l-Qa'da 889/5 December 1484: Amari, I diplomi: Appendice 46 (no. XXXI of the seconda serie).

15. Draft of a decree to be issued by Qāytbāy to the authorities of Florence datable to 893/1488:285 Amari, I diplomi 363-71 (no. XLV of the seconda serie); Rizzo, Le Lys et le Lion ii, 299-307.

16. Decree of Qāytbāy addressed to the authorities of Alexandria dated 6 Muharram 894/14 December 1488: Amari, I diplomi 382-6 (no. XLVIII of the seconda serie).

285 There is an authenticated copy of this document in MS 49 (Florence, National Library, Fondo del Furia). See Wansbrough, A Mamlūk commercial treaty $5^{\circ}$ (no. D). 
17. Decree with safe-conduct issued by Qānșawh al-Ghawrī regarding the Florentines dated Rajab-Sha'bān 914/November 1508: Amari, I diplomi 388 (no. L of the seconda serie); Rizzo, Le Lys et le Lion ii, 321-2.

18. Decree of Qānșawh al-Ghawrī addressed to the authorities of Alexan-

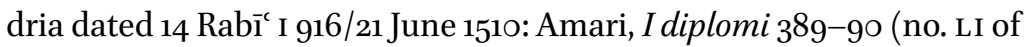
the seconda serie); Rizzo, Le Lys et le Lion ii, 323-4.

19. Letter of Qānșawh al-Ghawrī to the authorities of Alexandria dated 14 Rabī' I 916/21 June 1510: Amari, I diplomi 391-2 (no. LII of the seconda serie); Rizzo, Le Lys et le Lion ii, 325-6.

\subsubsection{Florentine Documents}

20. Instructions given to the two ambassadors, Felice Brancacci and Carlo Federighi, designated by the Florentine authorities dated 14 June 1422: Amari, I diplomi 331-5 (no. XXXVII of the seconda serie); Rizzo, Le Lys et le Lion ii, $269-73$.

21. Letter of the Florentine authorities to al-Ashraf Barsbāy dated 15 January 1435: Amari, I diplomi: Appendice 15-16 (no. v); Rizzo, Le Lys et le Lion ii, $289-90$.

22. Letter of the Florentine authorities to al-Zāhir Jaqmaq dated 11 May 1445: Amari, I diplomi: Appendice 17-8 (no. vi); Rizzo, Le Lys et le Lion ii, 291-2.

23. Letter of the Florentine authorities to the authorities of Alexandria dated 11 May 1445: Amari, I diplomi: Appendice 18 (no. vi).

24. Letter of the Florentine authorities to al-Zāhir Khushqadam dated 14 August 1465: Amari, I diplomi: Appendice 38-9 (no. XXII); Rizzo, Le Lys et le Lion ii, 293-4.

25. Letter of the Florentine authorities to the governor of Alexandria dated 14 August 1465: Amari, I diplomi: Appendice 39-40 (no. XXII).

26. Letter of the Florentine authorities to Qāytbāy dated 28 February 1476: Amari, I diplomi: Appendice 43 (no. XXVIII); Rizzo, Le Lys et le Lion ii, 295.

27. Letter of the Florentine authorities to the governor of Alexandria dated 28 February 1476: Amari, I diplomi: Appendice 43-4 (no. XXVIII).

28. Emendations proposed by Florentine merchants to doc. no. 15 dated 27 November 1487: Amari, I diplomi 361-2 (no. XLIV of the seconda serie); Rizzo, Le Lys et le Lion ii, 297-8.

29. Letter of Lorenzo de' Medici addressed to al-Ashraf Qāytbāy dated 10 June 1488: Bandini, Collectio 12-13.

30. Instructions given to the ambassador Luigi della Stufa dated 15 Novem- 
ber 1488: Amari, I diplomi 372-3 (no. XLVI of the seconda serie); Meli, Firenze 260-1 (no. 2); Rizzo, Le Lys et le Lion ii, 309-10.

31. Petition made by the Florentine ambassador Luigi della Stufa to alAshraf Qāytbāy datable to 1488: Amari, I diplomi 374-81 (no. XLVII of the seconda serie); Rizzo, Le Lys et le Lion ii, 311-8.

32. Letter of the Florentine authorities to Qānșawh al-Ghawrī dated 13 April 1507: Amari, I diplomi 387 (no. XLIX of the seconda serie); Rizzo, Le Lys et le Lion ii, 319 .

\subsection{Venice}

7.3.1 Mamluk Documents

7.3.1.1 Original Documents

1. Letter of al-Ashraf Qāytbāy to the doge dated 1o Sha'bān 877/10 January 1473: Labib, Ein Brief; Wansbrough, A Mamluk letter; Hours, Fraude commerciale.

2. Request made to Venice for payment of the Cyprus tribute with receipt of the amount dated, respectively, 6 Dhū l-Hijja 895/21 October 1490 and 22 Dhū l-Qa'da 895/7 October 1490 (Documenti Algeri, Egitto, Marocco, busta unica: Egitto, no. 2a): unpublished. ${ }^{286}$

3. Draft of a decree to be issued by Țūmān Bāy (r. 922-3/1516-7) regarding the Venetian merchants dated 22 Muharram 923/14 February 1517 (Oriental Institute Museum (Chicago), no. 13789): Moritz, Ein Firman; Hartmann, Das Privileg. ${ }^{287}$

\subsubsection{Translations}

4. Decree issued by al-Mucizz Aybak (r. 648-55/1250-7) regarding the Venetian merchants dated 13 Dhū l-Qa'da 652/13 November 1254:288 Tafel/Thomas, Urkunden ii, 483-9 (no. cccxxv); de Mas Latrie, Traités iii, $77-8$ o (no. IV).

5. Letter of [al-Manșūr 'Alī b.] al-Mu'izz Aybak to the doge dated 8 Dhū lQa'da 656/5 December 1258:289 Tafel/Thomas, Urkunden ii, 490-1 (nos. CCCXXVI-CCCXXVII).

286 To be published by F. Bauden.

287 See also Frantz-Murphy's article in this volume.

288 The date indicated according to the Muslim era (the translation gives a corrupted form for the month "Gsuc" which must correspond to Dhū l-Qa'da, not Shawwāl as suggested by Tafel and Thomas) fell on 25 December 1254. For another interpretation of Gsuc, see Mourkarzel's article in this volume, p. 705 .

289 The year is not indicated for the Muslim date. The date given according to the Common Era fell on 6 November 1258. Al-Mu'izz Aybak died in 655/1257 and his son was on the throne at the time this document was allegedly issued. 
6. Safe-conduct issued by al-Manșūr Qalāwūn (r. 678-89/1279-9o) for the Venetian merchants dated 29 Shawwāl 687/26 November 1288: de Mas Latrie, Traités iii, 81-82 (no. VI).

7. Safe-conduct issued by al-Nāșir Muhammad for the Venetian merchants dated 6 Dhū l-Hijja 701/2 August 1302: Thomas/Predelli, Diplomatarium i, 5 (no. 4); de Mas Latrie, Traités iii, 82 (no. VII/i).

8. Decree issued by al-Nāṣir Muḥammad regarding the Venetian merchants dated 9 Dhū l-Hijja 701/5 August 1302: Thomas/Predelli, Diplomatarium i, 5-9 (no. 4); de Mas Latrie, Traités iii, 83-5 (no. VII/ii).

9. Letter of al-Nāșir Muhammad addressed to the governor of Alexandria dated 11 Dhū l-Hijja 701/7 August 1302: Thomas/Predelli, Diplomatarium i, 9-10 (no. 5); de Mas Latrie, Traités iii, 86-7 (no. viı/i).

10. Decree issued by al-Nāșir Muhammad and addressed to the Alexandrian authorities dated 11 Dhū l-Hijja 701/7 August 1302: Thomas/Predelli, Diplomatarium i, 10-11 (no. 5); de Mas Latrie, Traités iii, 87 (no. VIII/ii).

11. Letter of the governor of Alexandria to the doge dated 22 Dhū l-Hijja 701/18 August 1302: Thomas/Predelli, Diplomatarium i, 11-2 (no. 6); de Mas Latrie, Traités iii, 87-8 (no. viII/iii).

12. Letter of the governor of Alexandria addressed to the doge datable to 703-4/1304: Thomas/Predelli, Diplomatarium i, 25 (no. 13).

13. Letter of the governor of Safad addressed to the doge dated Șafar 704/September 1304: Thomas/Predelli, Diplomatarium i, 30-1 (no. 17).

14. Letter addressed by al-Ṣālih Ismāîl (r. 743-6/1342-5) to the doge datable to Ramaḍān-Shawwāl 744/February 1344: Thomas/Predelli, Diplomatarium i, 290-2 (no. 153).

15. Decree issued by al-Ṣaliḥ Ismācil regarding the Venetian merchants datable to 744/1344: Thomas/Predelli, Diplomatarium i, 292-6 (no. 154).

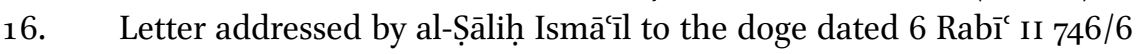
August 1345: Thomas/Predelli, Diplomatarium i, 296-7 (no. 155).

17. Decree issued by al-Nāșir Ḥasan regarding the Venetian merchants datable to 756/1355: Thomas/Predelli, Diplomatarium ii, 19-23 (no. 12); de Mas Latrie, Traités iii, 88-92 (no. Ix/i).

18. Letter of the supreme judge of Cairo to the governor and the judge of Alexandria dated 5 Dhū l-Qa'da 756/11 November 1355: Thomas/Predelli, Diplomatarium ii, 24 (no. 13); de Mas Latrie, Traités iii, 92 (no. IX/ii).

19. Decree issued by al-Manșūr Muhammad (r. 762-4/1361-3) regarding 
the Venetian merchants dated 1 Șafar 763/3o November 1361: Thomas/ Predelli, Diplomatarium ii, 8o (no. 47); de Mas Latrie, Traités iii, 93 (no. $\mathrm{x}$ ).

2o. Letter of al-Ashraf Sha'bān (r. $764-78 / 1363-77)$ to the doge, Marco Cornaro, datable to $767-8 / 1366$ : Thomas/Predelli, Diplomatarium ii, 113-5 (no. 68).

21. Decree issued by al-Ashraf Shacbān regarding the Venetian merchants datable to 776-7/1375: Thomas/Predelli, Diplomatarium ii, 168-71 (no. 10o); de Mas Latrie, Traités iii, 93-4 (no. XI).

22. Letter of al-Mu'ayyad Shaykh to the doge, Tommaso Mocenigo (r. 141423), dated 12 Rajab 818/15 November 1415: Thomas/Predelli, Diplomatarium ii, 306-8 (no. 167).

23. Decree issued by al-Mu'ayyad Shaykh regarding the Venetian merchants and addressed to the authorities of the sultanate dated 12 Rajab 818/15 November 1415: Thomas/Predelli, Diplomatarium ii, 309-15 (no. 168).

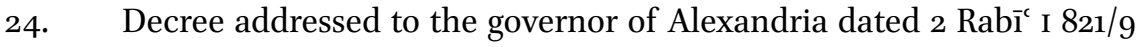
April 1418 (Procuratori di San Marco, Misti, busta 180, fasc. IX, no. 1, recto): unpublished.

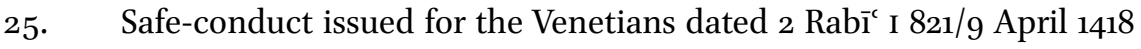
(Procuratori di San Marco, Misti, busta 180, fasc. IX, no. 1, verso): unpublished.

26. Decree issued by al-Ashraf Barsbāy regarding the Venetian merchants and addressed to the authorities of the sultanate dated 1 Jumādā I 825/23 April 1422: Thomas/Predelli, Diplomatarium ii, 320-7 (no. 174).

27. Letter of al-Ashraf Barsbāy to the doge, Tommaso Mocenigo, dated 8 Jumādā I 825/30 April 1422: Thomas/Predelli, Diplomatarium ii, 328-31 (no. 175).

28. Decree issued by al-Zāhir Jaqmaq regarding the Venetian merchants and addressed to the authorities of the sultanate dated 27 Jumādā I 846/1 October 1442:290 Amari, I diplomi 347-53 (no. XLII); Thomas/Predelli, Diplomatarium ii, 353-8. (nos. 189-9o); Wansbrough, Documents, no. I; Wansbrough, Venice and Florence 487-97.

29. Decree issued by al-Zāhir Jaqmaq and addressed to the governor of Damietta dated 27 Jumādā I 846/1 October 1442: Amari, I diplomi 353-4; Thomas/Predelli, Diplomatarium ii, 359-6o (no. 191).

290 The date indicated in the document (29) is the result of a misinterpretation of the unit. The other documents related to this one (see nos. 29-31) give 27 Jumādā I which, in any case, fell on 3 October 1442. 
30. Decree issued by al-Zāhir Jaqmaq and addressed to the governor of Beirut (?) dated 27 Jumādā I 846/1 October 1442: Amari, I diplomi 354 (summary only); Thomas/Predelli, Diplomatarium ii, 360 (no. 192) (summary only).

31. Decree issued by al-Zāhir Jaqmaq and addressed to the prefect of Cairo dated 27 Jumādā I 846/1 October 1442: Amari, I diplomi 354-5; Thomas/Predelli, Diplomatarium ii, 36o-1 (no. 193).

32. Decree issued by al-Zāhir Jaqmaq and addressed to the governor of Alexandria dated 27 Jumādā I 846/2 October 1442: Amari, I diplomi 3556; Thomas/Predelli, Diplomatarium ii, 361-2 (no. 194).

33. Letter of al-Zāhir Jaqmaq to the doge, Francesco Foscari (r. 1423-57), dated 5 Jumādā II 846/25 October 1442: ${ }^{291}$ Amari, I diplomi 357-9; Thomas/Predelli, Diplomatarium ii, 362-4 (no. 195).

34. Letter of 'Uthmān, son of al-Zāhir Jaqmaq to the doge, Francesco Foscari, dated 25 Jumādā II 846/29 October 1442:292 Amari, I diplomi 359; Thomas/Predelli, Diplomatarium ii, 364-5 (no. 196).

35. Decree issued by al-Z̄āhir Jaqmaq and addressed to the governor of Alexandria dated 24 Jumādā II 846/30 October 1442: Amari, I diplomi 356-7; Thomas/Predelli, Diplomatarium ii, 365-6 (no. 197).

36. Letter of al-Zāhir Jaqmaq to the doge, Francesco Foscari, dated 26 Rabīc I 853/21 May 1449:293 Thomas/Predelli, Diplomatarium ii, 373-6 (no. 197).

37. Letter of al-Zāhir Jaqmaq to the governor of Amman datable to Rabī' I 853/May 1449: Thomas/Predelli, Diplomatarium ii, 374-5 (no. 197).

38. Decree of al-Zāhir Jaqmaq addressed to the governor of Beirut datable to Rabī' I 853/May 1449: Thomas/Predelli, Diplomatarium ii, 375-7 (no. 197).

39. Decree of al-Zāhir Jaqmaq addressed to the governor of Tripoli datable to Rabī' I 853/May 1449: Thomas/Predelli, Diplomatarium ii, 377-8 (no. 197).

40. Letter of al-Mu'ayyad Ahmad (r. 865/1461) to the doge dated 5 Ramaḍān 865/13 June 1461: Wansbrough, Documents, no. II; Pedani, Gli ultimi accordi $56-7$ (no. I).

41. Letter addressed by the executive secretary (dawādār) to the Venetian authorities dated 877/1473: Arbel, Levantine power struggles.

291 The date indicated corresponded to 11 October 1442.

292 The date indicated corresponded to 31 October 1442.

293 The date indicated corresponded to 19 May 1449. 
42. Decree of al-Ashraf Qāytbāy addressed to the governor of Damascus dated 17 Șafar 895/9 January 1490:294 Rossi, Ambasciata 127 (no. 51).

43. Decree of al-Ashraf Qāytbāy addressed to the governor of Damascus and the inspector of the privy dated 26 Șafar 895/19 January 1490: Rossi, Ambasciata 140-1 (no. 64).

44. Murabba' decree issued by al-Ashraf Qāytbāy regarding the Venetian merchants dated 27 Șafar 895/20 January 1490: Wanbrough, Documents, no. III; Rossi, Ambasciata 232-3 (no. 144).

45. Decree of al-Ashraf Qāytbāy addressed to the governor of Alexandria dated 6 Rabī I 895/28 January 149o: Rossi, Ambasciata 145-6 (no. 69).

46. Treaty between the Republic of Venice and the Mamluk sultanate to transfer Cyprus under Venetian rule dated 7 Rabī II 895/28 February 1490: Rossi, Ambasciata 226-7 (no. 139).

47. Contract between al-Ashraf Qāytbāy and the Venetian ambassador for the transition of the island of Cyprus to Venetian authority, dated 17 Rabī' II 895/9 March 149o: de Mas Latrie, Histoire iii, 478-81; facsimile and edition in Iskandar, Documents inédits, no. III; Arabic translation in Iskandar, Ta’rīkh Miṣr, no. III; Rossi, Ambasciata 227-9.

48. Decree of al-Ashraf Qāytbāy addressed to the governor of Damascus datable to Rabī' II 895/March 149 o (summary only): Rossi, Ambasciata 234-5 (no. 146).

49. Decree of al-Ashraf Qāytbāy addressed to the governor of Alexandria datable to Rabī' II 895/March 149 o (summary only): Rossi, Ambasciata 235-6 (no. 146).

50. Decree of al-Ashraf Qāytbāy addressed to the governor of Aleppo datable to Rabī' II 895/March 149 o (summary only): Rossi, Ambasciata 236 (no. 146).

51. Receipt for the payment of an installment of the Cyprus tribute by the Venetian Republic to the Mamluk sultanate dated 18 Rabī' II 895/11 March 1490: de Mas Latrie, Histoire iii, 481.

52. Letter of al-Ashraf Qāytbāy to the doge, Agostino Barbarigo, datable to Rabī' II 895/March 149o: de Mas Latrie, Histoire iii, 481-3.

53. Letter of the governor of Alexandria addressed to the doge and dated 23 Jumādā I 9oo/19 February 1495: Sanuto, Diarii i, cols. 133-5.

54-5. Two letters of al-Zāhir Qānșawh I addressed to the Venetian represen-

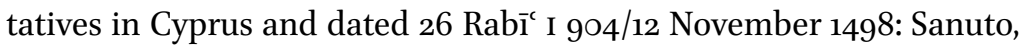
Diarii ii, cols. 614, 614-616.

294 The date indicated corresponded to 10 January 1490. 
56. Letter of Qānșawh al-Ghawrī addressed to the doge (reached Venice in December 1501): Sanuto, Diarii iv, cols. 187-8 ('unwān (inscriptio and intitulatio) only).

57. Letter of Qānșawh al-Ghawrī addressed to the doge and dated 4 Ṣafar 909/29 July 1503: Sanuto, Diarii v, cols. 887-8.

58. Letter of Qānșawh al-Ghawrī addressed to the doge and dated 4 Ṣafar 909/29 July 1503: Sanuto, Diarii v, cols. 887-8 (summary translated in Alexandria) and 888-9o (full text).

59. Letter of Qānșawh al-Ghawrī to the doge dated 27 Sha'bān 9o9/14 February 1504: Wansbrough, Documents, no. IV/i; Pedani, Gli ultimi accordi 57-9 (no. II).

6o. Murabba decree issued by Qānșawh al-Ghawrī regarding the Venetian merchants datable to 27 Sha'bān 9o9/14 February 1504: Wansbrough, Documents, no. IV/ii; Pedani, Gli ultimi accordi 59-6o (no. III).

61. Letter of Qānșawh al-Ghawrī addressed to the doge and dated 8 Shawwāl 911/4 March 1506: Sanuto, Diarii vii, cols. 203-7 and 207-10.

62. Letter of Qānșawh al-Ghawrī addressed to the doge and dated 16 Shawwāl 912/1 March 1507: Sanuto, Diarii vii, cols. 215-20.

63. Treaty concluded between Venice and the Mamluk ambassador Taghrī Birdī dated 18 Muharram 913/31 May 1507: Wansbrough, Documents, no. v; Wansbrough, A Mamluk ambassador.

64. Decree of Qānșawh al-Ghawrī regarding the Venetian merchants issued in Rajab 913/November 1507: Sanuto, Diarii vii, cols. 596-7.

65. Letter of Qānșawh al-Ghawrī addressed to the doge and dated 25 Muharram 916/4 May 1510: Sanuto, Diarii xi, cols. 115-7.

66. Letter of the governor of Alexandria to the doge received in August 1510: Sanuto, Diarii xi, col. 106.

67. Decree issued by Qānșawh al-Ghawrī regarding the Venetian merchants dated 20 Rabī' I 918/5 June 1512: Marin, Storia vii, 288-321; Reinaud, Traités (French trans. only); Wansbrough, Documents, no. $\mathrm{VI} / \mathrm{i}$.

68. Decree issued by Qānșawh al-Ghawrī regarding the Venetian merchants dated Rabīi II-Jumādā I 918/July 1512: Wansbrough, Documents, no. vi/ii; Pedani, Gli ultimi accordi 6o-2 (no. IV).

69. Letter of Qānșawh al-Ghawrī addressed to the doge dated 16 Jumādā I 918/30 July 1512: Sanuto, Diarii xv, cols. 264-6.

70. Decree issued by Qānșawh al-Ghawrī and addressed to the governor of Alexandria dated Rabīc II-Jumādā I 918/July 1512: Wansbrough, Documents, no. vi/iii; Pedani, Gli ultimi accordi $62-4$ (no. v).

71. Decree issued by Qānșawh al-Ghawrī and addressed to the governor 
of Damascus datable to Rabī' II-Jumādā I 918/July 1512: Wansbrough, Documents, no. VI/iv.

72. Decree issued by Qānșawh al-Ghawrī and addressed to the governor of Tripoli datable to Rabī‘ II-Jumādā I 918/July 1512: Wansbrough, Documents, no. vi/v.

73. Decree issued by Qānșawh al-Ghawrī and addressed to the governor of Aleppo datable to Rabī‘ II-Jumādā I 918/July 1512: Wansbrough, Documents, no. vi/vi.

74. Letter of Qānșawh al-Ghawrī addressed to the doge dated 28 Rabī' $^{\mathrm{c}}$ II 920/22 June 1514: Sanuto, Diarii xix, cols. 42-5.

75. Decree of Qānșawh al-Ghawrī regarding the Venetian merchants in Alexandria dated 17 Dhū l-Qa'da 920/3 January 1515: Sanuto, Diarii xx, cols. 171-3

76. Decree of Qānșawh al-Ghawrī regarding the Venetian merchants in Damietta datable to 17 Dhū l-Qa'da 920/3 January 1515: Sanuto, Diarii $\mathrm{xx}$, cols. $173-4$.

77. Letter of Qānșawh al-Ghawrī addressed to the doge dated 18 Muharram 921/4 March 1515: Sanuto, Diarii xx, cols. 357-6o.

\subsubsection{Venetian Documents}

78. Instructions delivered by the doge, Tommaso Mocenigo, to the two ambassadors Bernardo Loredan and Lorenzo Capello dated 23 December 1421: Thomas/Predelli, Diplomatarium ii, 332-40 (no. 176).

79. Instructions delivered by the doge, Agostin Bargarigo (r. 1486-1501), to his ambassador Pietro Diedo dated 10 September 1489: de Mas Latrie, Histoire iii, 472-8; Rossi, Ambasciata 259-4 (no. XV).

8o. Letter of the doge, Leonardo Loredano (r. 1501-21), to Qānșawh alGhawrī dated 26 October 1506: Sanuto, Diarii vii, cols. 211-14.

7.4 Ragusa

7.4.1 Mamluk Documents

7.4.1.1 Original Documents

1. Letter of the governor of Alexandria addressed to the ruler of Ragusa

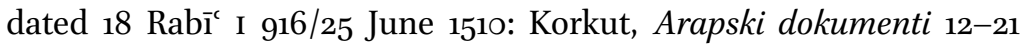
(no. 1).

2. Letter of Qānșawh al-Ghawrī addressed to the ruler of Ragusa dated 1 Shawwāl 921/8 November 1515: Korkut, Arapski dokumenti 22-37 (no. 2).

3. Decree issued by Qānșawh al-Ghawrī for the establishment of a Ragu- 
san consulate in Alexandria dated 18 Shawwāl 921/25 November 1515: Korkut, Arapski dokumenti 38-53 (no. 3).

\subsection{Ottomans}

\subsubsection{Mamluk Documents}

\subsubsection{Original Document}

1. Letter of Khāiir Bāy, governor of Aleppo, addressed to Bāyazīd II (r. 886-918/1481-1512) dated 7 Rabī' I 917/4 June 1511 (Başbakanlık Arşivi, İbnü'l-emin Hariciye 1, T.E. 5483): unpublished. ${ }^{295}$

2. Letter of Qānșawh al-Ghawrī addressed to Selīm I (r. 918-26/1512-20) dated 29 Ṣafar 922/3 April 1516: Edhem, Misır Fethi 30-1.

\subsubsection{Translation}

3. Letter of Qānșawh al-Ghawrī addressed to Bāyazīd II, undated but linked to an embassy that took place in Rabī' II 916/July 1510 (Başbakanlık Arşivi, İbnü'l-emin Hariciye 1, T.E. 5464): unpublished. ${ }^{296}$

\subsubsection{Ottoman Document}

4. Letter of Mehmed II (r. 848-50/1444-6, 855-86/1451-81) addressed to al-Ashraf Qāytbāy dated Dhū l-Hijja 881/March-April 1477 (Başbakanlık Arşivi, İbnüll-emin Hariciye 1, T.E. 5848): unpublished. ${ }^{297}$

\subsection{France \\ 7.6.1 Mamluk Document \\ 7.6.1.1 Original}

1. Decree issued by Qānșawh al-Ghawrī regarding the Catalan and French merchants dated 1 Rabī' II 913/10 August 1507: we do not have a preserved copy, but it was largely reproduced in the decree issued by Sulaymān II (r. 926-74/1520-66) regarding the same merchants dated 6 Muharram 935/20 September $1528 .{ }^{298}$

\subsubsection{Translations}

2. Letter of al-Ẓāhir Jaqmaq to Charles viI (r. 1422-61) datable to 8501/1447: d'Escouchy, Chronique i, 121-4.

295 Yüksel Muslu, The Ottomans 273.

296 Yüksel Muslu, The Ottomans 271.

297 Yüksel Muslu, The Ottomans 247.

298 Published, with French translation, by M. Tuchscherer in Tuchscherer and Pedani, Alexandrie ottomane 1 32-41. 
3. Letter of Qānșawh al-Ghawrī to Louis XII (r. 1498-1515) dated 14 Shabān 916/16 November 1510: Le Maire de Belges, Le Traictié (an unpaginated excerpt at the end of the book). ${ }^{299}$

7.6.2 French Documents

4. Letter of Charles VII to al-Zāhir Jaqmaq dated 20 August 1451: Anonymous, Recueil d'actes, fol. 194.

5. Undated letter of Charles VII to al-Z̄āhir Jaqmaq: Anonymous, Recueil d'actes, fols. $252 \mathrm{a}-\mathrm{b}$.

6. Letter of Louis XI (r. 1461-83) to al-Ashraf Qāytbāy datable to the end of 1481: Anonymous, Recueil de lettres, fols. 112a-b; Vaesen, Lettres 136-8.

7.7 Cyprus

7.7.1 Mamluk Documents

7.7.1.1 Translations

1. Letter of al-Ashraf Īnāl to John II (r. 1432-58) datable shortly after Rabī I 857/March 1453: de Mas Latrie, Histoire iii, $73-5 \cdot \cdot^{300}$

2. Letter of Qāytbāy to Catherine Cornaro (r. 1474-89) dated 10 Muharram 881/5 May 1476: de Mas Latrie, Histoire iii, 405-6.

\subsubsection{Cypriot Document}

3. Instructions given by Peter I (r. 1359-69) to the Venetian and Genoan ambassadors to negotiate a truce with the sultan on his behalf dated 19 May 1368: de Mas Latrie, Histoire ii, 302-8; Thomas/Predelli, Diplomatarium ii, 132-9 (no. 81).

\subsection{Hospitallers of Rhodes}

7.8.1 Documents Issued by the Hospitallers

1. Proposal from the grand master to al-Nāșir Faraj for a treaty, dated 4 November 1403: Paoli, Codice diplomatico 108-10 (no. LXXXVI).

299 See also the copy in Rey, La Protection 111, n. 2. This appears to be a truncated copy. For a much longer version of the same letter translated in Venetian, see Sanuto, Diarii xii, cols. 624-3o.

300 Wrongly dated to 1 Muharram 861/29 November 1456 by de Mas Latrie. For the correct date, see below 729-30. 
2. Letter from the grand master to al-Zāhir Jaqmaq dated 20 November 1448: de Mas Latrie, Histoire iii, $55^{-6 .}$

\subsection{Genoa}

\subsubsection{Mamluk Document}

\subsubsection{Translation}

1. Truce between Qalāwūn and Genoa dated 13 May 129o: de Sacy, Pièces diplomatiques $33^{-52}$ (edition of the Arabic text in Ibn 'Abd al-Z̄āhir, Tashrîf al-ayyām and of the Latin translation of a second version that de Sacy found in the Genoese archives, that includes the viceregent's oath on the sultan's behalf); Amari, Nuovi ricordi 6o6-14 (Italian translation); Belgrano, Trattato (edition of the Latin translation); Holt, Early Mamluk Diplomacy 146-51 (English translation of the Arabic text).

\subsection{Naples}

7.10.1 Neapolitan Document

1. Letter of Joanna I (r. 1344-82) to al-Ashraf Sha'bān dated 22 May 1363: Golubovich, Biblioteca iv, 50-1.

\subsection{Pisa}

7.11.1 Pisan Document

1. Letter of credentials for the ambassador who was sent to al-Zāhir Barqūq dated 5 August 1385: Amari, I diplomi 315-6 (no. XXXIII).

\subsection{Savoy}

7.12.1 Savoyard Document

1. Letter sent by Charles I (r. 1482-90) to al-Ashraf Qāytbāy dated 18 August 1488 (draft: ASTo, Regno di Cipro, 1 d'addizione, letter no. 14 (18 August 1488)). ${ }^{301}$

301 Mentioned in Lazzarini, Écrire à l' autre 177.

\section{For use by the Author only | (C) 2019 Koninklijke Brill NV}




\section{Bibliography}

\section{Primary Sources (Handwritten)}

Anonymous, al-Durar al-manthūrāt [sic], Ms Vollers 663, Leipzig, Universitätsbibliothek.

Anonymous, Ijābat al-sāil ilā ma'rifat al-rasāìl, Ms Arabe 4437, Paris, BnF.

Anonymous, Munsha'a (Arabic), Ms Arabe 4440, Paris, BnF; Ms 1899, Algiers, Bibliothèque nationale.

Anonymous, Muzīl al-ḥaṣr fì mukātabāt ahl al-'așr, Ms Árabe 566, San Lorenzo de El Escorial, Biblioteca de El Escorial; Ms Petermann 299, Berlin, Staatsbibliothek.

Anonymous, Recueil d'actes des rois Charles VII et Louis XI, MS Français 5909, Paris, BnF. Anonymous, Recueil de lettres et de pièces originales, Ms Français 2893, Paris, BnF.

Anonymous, Zuhrat al-nāzirīn wa-nuzhat al-nädhirīn, Ms Or. 1052, Leiden, Universiteitsbibliotheek.

al-Ḥalabī, Shams al-Dīn Abū 'Abdallāh Muḥammad al-Ḥanafì, al-Tibyān fi ș̣ilāḥ ahl alzamān, Ms Mf72, Berlin, Staatsbibliothek.

Ibn Fạ̣l Allāh al-'Umarī, al-Nubdha al-kāfiya fìma'rifat aw d̦ā' al-kitāba wa-l-qāafiya, Ms Vollers 493, Leipzig, Universitätsbibliothek.

Ibn Faḍl Allāh al-'Umarī, al-Tarassulfíqawā'id al-mukātabāt, MS 2479, fols. 42-58, Istanbul, Topkapı Sarayı Müzesi Kütüphanesi.

Ibn al-Ḥanbalī, 'Abdallāh b. Muḥammad al-Zakī al-Ghazzī l-Ḥanafì, al-Murūjal-zakìyya fi tawshiyat al-durūj al-khițābiyya, Ms Árabe 557, San Lorenzo de El Escorial, Biblioteca de El Escorial; MS 471, Riyadh, Maktabat Jāmi'at al-Malik Sa'ūd; MS 4766, fols. 220-78, Tunis, Dār al-Kutub al-Wațaniyya.

Ibn Hiijja, Qahwat al-insh $\vec{a}$, Ms Sprenger 1223, Berlin, Staatsbibliothek; MS 1898, Algiers, Bibliothèque nationale.

Ibn al-Qalqashandī, Qalāid al-jumān fìmuștalaḥ mukātabātahl al-zamān, MS OR. 3625, London, B L.

al-Qalqashandī, Aḥmad b. 'Abdallāh, al-Juz' al-awwwal min Daw' al-ṣuḅ̣ al-musfir wajanā l-dawh al-muthmir, ikhtișār Șubḥ al-a shā fi șinā'at al-inshä), MS A26o3, Istanbul, Topkapı Sarayı Müzesi Kütüphanesi; MS ‘Ayn 1122, Tehran, Kitābkhāna-yi Millī-i Jumhūrīi Islāmī-i Īrān.

al-Qalqashandī, Aḥmad b. 'Abdallāh, Șubḥ al-a sh hā fi șinā'at al-inshā', MS 1897, Algiers, Bibliothèque nationale.

al-Saḥmāwī, al-Thaghr al-bāsim fì șinā'at al-kātib wa-l-kātim, Ms Ar. 4439, Paris, BnF.

al-Saḥmāwī, al-'Urf al-nāsim 'alā l-Thag̉r al-bāsim fì șinā'at al-kātib wa-l-kātim, MS 13158 zāy, Cairo, Dār al-Kutub.

al-Ṭayyibī, Jāmi‘ maḥāsin kitābat al-kuttāb wa-nuzhat ūlì l-bașā̉ir wa-l-albāb, MS K882, Istanbul, Topkapı Sarayı Müzesi Kütüphanesi; Ms Ar. 97, Manchester, University of Manchester, John Rylands University Library. 


\section{Primary Sources (Printed)}

al-Baghdādī, Ismāīil Bāshā, Hadiyyat al- 'ārifin: asmā̄a al-mu'allifin wa-āthār al-mușannifin, ed. S. Yaltkaya and R. Bilge, 2 vols., Istanbul 1951.

al-Baghdādī, Ismā'īl Bāshā, Ị̇̂aḥ al-maknūn fì al-dhayl 'alā Kashf al-zunūun, ed. Ş. Yaltkaya and R. Bilge, 2 vols., Istanbul 1945.

Bandini, A.M., Collectio veterum aliquot monimentorum ad historiam praecipue litterariam pertinentium, Arezzo 1753.

d'Escouchy, Mathieu, Chronique, ed. G. du Fresne de Beaucourt, 3 vols., Paris 1863-4. Ferīdūn Beg, Mecmū'a-yi münşe'āt-i selāțīn, 2 vols., Istanbul 1857-9.

Ibn Faḍl Allāh al-'Umarī, al-Nubdha al-kāfiya fì ma'rifat awḍ̂a' al-kitāba, ed. 'A.M. Zīnū, Amman [2017].

Ibn Faḍl Allāh al-'Umarī, al-Ta'rīf bi-l-muștalah al-sarīf, ed. S. al-Durūbī, al-Karak 1992. Ibn Faḍl Allāh al-'Umarī, 'Urf al-ta'rīf fì l-mukātabāt: awwal dustūr fì l-alqāb al-tashrīfiyya fì lughat al-'Arab, ed. S. al-Durūbī, Amman 2008.

Ibn Hijja, Das Rauschgetränk der Stilkunst oder Qahwat al-inšā’ von Taqìyuddīn Abū Bakr. b. 'Alī Ibn Hiğğa al-Hamawī al-Azrārī, ed. R. Veselý, Beirut and Berlin 2005. Ibn Nāẓir al-Jaysh, Tathqüf al-ta'rīf bi-l-mușțalah al-sharīf, ed. R. Veselý, Cairo 1987. Ibn al-Ṣāìg, Tuḥfat al-albābfi șinā'at al-khațtwa-l-kitāb, ed. H. Nāḡī, Tunis 1981.

Kātib Çelebi, Kashfal-zunūn 'an asāmī al-kutub wa-l-funūn, ed. Ş. Yaltkaya and R. Bilge, 2 vols., Istanbul 1941.

Le Maire de Belges, J., Le Traictie intitule de la difference des scismes et des concilles de léglise et de la prééminence et utilité des concilles de la saincte église gallicaine, Lyon 1511.

López de Ayala, P., Crónica de Juan I, Madrid 1868.

al-Mawșilī, al-Burd al-muwashshā fì șinā'at al-inshā', ed. 'A.S. Șabra, Beirut 1990.

al-Qalqashandī, Daw' al-șubh al-musfirwa-janā l-dawh al-muthmir:mukhtașar Șubḥala'shā fi kitābat al-inshā', ed. M. Salāma, Cairo 1906.

al-Qalqashandī, Ma'āthir al-ināfa fı̀ ma'ālim al-khilāfa, ed. 'A. al-S.A. Farrāj, 3 vols., Kuwait 1964.

al-Qalqashandī, Selections from Șubḥ al-A'shā by al-Qalqashandī, clerk of the Mamluk court:Egypt, "Seats of government" and "Regulations of the kingdom," from early Islam to the Mamluks, trans. H. el-Toudy and T.G. Abdelhamid, London 2017.

al-Qalqashandī, Șubḥ al-a shā $f ı$ șinā'at al-inshā', ed. M.'A. al-R. Ibrāhīm, 14 vols., Cairo $1913-9,{ }^{2} 1963$.

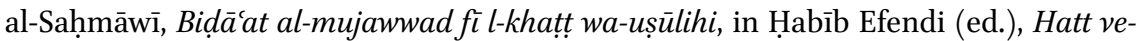
hattâtîn, 278-85; in H. Nājī (ed.), Nuṣūṣ fī l-khațt al-'arabī, in al-Mawrid 15/4 (1986), $249-58$.

al-Saḥmāwī, al-Thaghr al-bāsim fí șinā'at al-kātib wa-l-kātim, ed. A.M. Anas Mursī, 2 vols., Cairo 2009.

Sanuto, M., I diarii, ed. F. Stefani et al., $5^{8}$ vols., Venice 1879-19o3.

\section{For use by the Author only | (C) 2019 Koninklijke Brill NV}


al-Ṭayyibī, Jāmi maḥāsin kitābat al-kuttāb wa-nuzhat ūlì l-bașā̉ir wa-l-albāb, facsimile edition Ș. al-D. al-Munajjid, Beirut 1962; edition and facsimile of 'A. al-'A. b. N. alMānic, Riyadh 2015.

al-Zaftāwī, Minhāj al-iṣāba fìma'rifat al-khuțūțwa-ālāt al-kitāba, in H. Nājī (ed.), Nuṣūṣ fì l-khațt al-'arabī, in al-Mawrid 15/4 (1986), 185-248.

\section{Secondary Sources}

'Abd al-Karìm, A.'I. (ed.), Abū l-Abbās al-Qalqashandī wa-kitābuhu "Ṣubḥ al-aśshā," Cairo 1973 .

Afshar, I., Catalogue of Persian manuscripts in the Austrian National Library and in the Austrian State Archives in Vienna, Tehran and Vienna 2003.

Aigle, D., Rédaction, transmission, modalités d'archivage des correspondances diplomatiques entre Orient et Occident (XIII ${ }^{\mathrm{e}}$-début XVI ${ }^{\mathrm{e}}$ siècle), in La Correspondance entre souverains, princes et cités-états: Approches croisées entre l'Orient musulman, l'Occident et Byzance, Turnhout 2013, 9-26.

Aigle, D. and M. Bernardini (eds.), Correspondances diplomatiques et traités de chancellerie, in Es XI/1-2 (2013), Rome and Halle 2013.

Aigle, D. and P. Buresi (eds.), Les Relations diplomatiques entre le monde musulman et l'occident latin (XII ${ }^{e}-X V I^{e}$ siècle), in $O M$ LXXXVI/1 (2008), Rome 2008.

Aigle, D. and S. Péquignot (eds.), La Correspondance entre souverains, princes et citésétats: Approches croisées entre l'Orient musulman, l'Occident et Byzance (XIII $I^{e}$-début $X V I^{e}$ siècle), Turnhout 2013.

Alarcón y Santón, M.A., and R.Y.T.P. García de Linares, Los documentos árabes diplomáticos del Archivo de la Coroña de Aragón, Madrid 1940.

al-Droubi, S., A critical edition of and study on Ibn Faḍl Allāh's manual of secretaryship "al-Ta'rîf bi'l-muștalaḥ al-sharīf," al-Karak 1992.

al-Musawi, M., Pre-modern belletristic prose, in R. Allen and D.S. Richards (eds.), Arabic Literature in the post-classical period, Cambridge 2006, 101-33.

Amari, M., Biblioteca arabo-sicula ossia raccolta di testi arabici che toccano la geografia, la storia, le biografie e la bibliografia della Sicilia, Leipzig 1857.

Amari, M., I diplomi arabi del R. Archivio fiorentino, Florence 1863.

Amari, M., I diplomi arabi del R. Archivio fiorentino: Appendice, Florence 1867.

Amari, M., La guerra del vespro siciliano, 4th ed., Florence 1851.

Amari, M., Nuovi ricordi arabici su la storia di Genova, Genoa 1873.

Amari, M., Trattato stipolato da Giacomo II di Aragona col Sultano d'Egitto il 29 gennaio 1293, in Atti della R. Accademia dei Lincei, ser. 3, XI (1883), 423-44.

Amitai-Preiss, R., An exchange of letters in Arabic between Abaya İlkhān and Sultan Baybars (A.H.667/A.D. 1268-69), in CAJ 38 (1994), 11-33.

Anas Mursī, A.M., Kutub al-dasātìr fì 'aṣr al-Mamālīk (658-923 h.) (1256-1517 m.) ma'a tahqūq wa-dirāsat makhțūṭal-Khālidī (al-Maqșid al-rafī̌ al-munshā al-hādī li-dīwān al-inshā'), PhD dissertation, Jāmi'at al-Manșūra 2004.

\section{For use by the Author only | (C) 2019 Koninklijke Brill NV}


Arbel, B., Levantine power struggles in an unpublished Mamluk letter of $877 \mathrm{AH} /$ 1473 CE, in MHR 7 (1992), 92-100.

Archival knowledge cultures in Europe, 1400-1900, special issue of Archival Science 10/3 (September 2010).

Archival transformations in Early Modern Europe, special issue of European History Quaterly 46/3 (July 2016).

Atanasiu, V., De la fréquence des lettres et de son influence en calligraphie arabe, Paris and Montréal 1999.

Atanasiu, V., Le Phénomène calligraphique à l'époque du sultanat mamluk: MoyenOrient, XIII ${ }^{e}-X V I^{e}$ siècle, $\mathrm{PhD}$ dissertation, École Pratique des Hautes-Études, Paris 2003.

Atiya, A.S., Egypt and Aragon: Embassies and diplomatic correspondence between 1300 and 1330 A.D., Leipzig 1938.

Atiya, A.S., Mamlūk correspondence with Aragon in the XIVth Century, ZDMG 91 (1937), p. ${ }^{*} 19$.

Bajraktarević, F., Die arabischen Urkunden des Staatsarchivs von Dubrovnik (Ragusa), in Der Islam 33 (1958), 135-41.

Banister, M., The Abbasid caliphate of Cairo (1261-1517): History and tradition in the Mamluk Court, PhD dissertation, Universiyt of Toronto 2015.

al-Baqlī, M., Fahāris Kitāb Șubḥ al-a shā fì șinā'at al-inshā' lil-Qalqashandī, Cairo 1972.

al-Bāshā, Ḥ., al-Alqāb al-islāmiyya fì l-tārīkh wa-l-wāthā’iq wa-l-āthār, Cairo 1957 (repr. 1989).

Bauden, F., L'Achat d'esclaves et la rédemption des captifs à Alexandrie d' après deux documents arabes d'époque mamelouke conservés aux Archives de l'État à Venise (ASVe), in A.-M. Eddé and E. Ganagé (eds.), Regards croisés sur le Moyen Âge arabe. Mélanges à la mémoire de Louis Pouzet s.j. (1928-2002), Beirut 2005, 269-325.

Bauden, F., A note on the production of recycled paper in the Mamluk period (forthcoming).

Bauden, F., Du destin des archives en Islam. Analyse des données et éléments de réponse, in D. Aigle and S. Péquignot (eds.), La Correspondance entre souverains, princes et cités-états: Approches croisées entre l'Orient musulman, l'Occident et Byzance (XIII ${ }^{e}$-début XVI ${ }^{e}$ siècle), Turnhout 2013, 27-49.

Bauden, F., Due trattati di pace conclusi nel dodicesimo secolo tra i Banū Gāniya, signori delle isole Baleari, e il comune di Genova, in N. Martínez de Castilla (ed.), Documentos y manuscritos árabes del Occidente musulman medieval, Madrid 2010, $33-86$.

Bauden, F., Ikhwāniyyāt letters in the Mamluk period: A document (muțāla'a) issued by al-Mu'ayyad Shaykh's chancery and a contribution to Mamluk diplomatics, in A. Levanoni (ed.), Egypt and Syria under Mamluk rule: Political, social and cultural aspects, Leiden and Boston (forthcoming). 
Bauden, F., Les Relations diplomatiques entre les sultans mamlouks circassiens et les autres pouvoirs du Dār al-islām. L' apport du ms. ar. 4440 (BNF, Paris), in AI 41 (2007), $1-29$.

Bauden, F., Le Transport de marchandises et de personnes sur le Nil en 823A.H./142O È.C., in A.T. Schubert and P.M. Sijpesteijn, Documents and the history of the early Islamic world, Leiden and Boston 2015, 100-29.

Bauden, F., Like father, like son: The chancery manual (Qalā’id al-Jumān) of al-Qalqašandi's son and its value for the study of Mamluk diplomatics (ninth/fifteenth century) (Studia Diplomatica Islamica, I), in ES XI/1-2 (2013), 181-228.

Bauden, F., Lists of gifts in the Mamluk diplomatic tradition, in F. Bauden (ed.), Culture matérielle et contacts diplomatiques entre l'Occident latin, Byzance et l'Orient islamique ( $\mathrm{XI}^{\mathrm{e}}-\mathrm{XVI} \mathrm{I}^{e}$ siècle), Leiden and Boston (forthcoming).

Bauden, F., The Mamluk documents of the Venetian State Archives: Handlist, in $Q S A$ 2O-1 (2002), 147-56.

Bauden, F., Mamluk era documentary studies: The state of the art, in MSR IX (2005), $15^{-6}$ o.

Bauden, F., Maqriziana II: Discovery of an autograph manuscript of al-Maqrīzī:Towards a better understanding of his working method, Analysis, in MSR XII/1 (2008), 51118.

Bauden, F., Maqriziana XIıI: An exchange of correspondence between al-Maqrīzī and al-Qalqashandī, in Y. Ben-Bassat (ed.), Developing perspectives in Mamluk history: Essays in honor of Amalia Levanoni, Leiden and Boston 2017, 201-29.

Bauden, F., Paper formats of the Mamluk period:The contribution of Mamluk chancery paper (forthcoming).

Bauden, F., The recovery of Mamlūk chancery documents in an unsuspected place, in M. Winter and A. Levanoni (eds.), The Mamluks in Egyptian and Syrian politics and society, Leiden and Boston 2004, 59-76.

Bauden, F., Yemeni-Egyptian diplomatic exchanges about the Meccan Sharifate in the light of a reconstructed Rasulid letter addressed to al-Mu'ayyad Shaykh in 817/1415, in F. Bauden (ed.), The Mamluk sultanate and its periphery, Leiden and Boston (forthcoming).

Bausi, A., C. Brockmann, M. Friedrich, and S. Kienitz (eds.), Manuscripts and archives: Comparative views on record-keeping, Berlin 2018.

Behrens-Abouseif, D., Practising diplomacy in the Mamluk sultanate: Gifts and material culture in the medieval Islamic world, London 2014.

Beihammer, A., Byzantinische Diplomatik: dead or alive?, in E. Jeffreys (ed.), Proceedings of the 21st International Congress of Byzantine Studies, London 21-26 August 2006, vol. 1: Plenary Papers, Aldershot 2006, 173-87.

Beihammer, A., M. Parani, and C. Schabel (eds.), Diplomatics in the Eastern Mediterranean, 1000-1500:Aspects of cross-cultural communication, Leiden and Boston 2008. 
Belgrano, L.T., Trattato del Sultano d'Egitto col comune di Genova nel MCCLXXXX, in Atti della Società Ligure di Storia Patria 19 (1888), 161-75.

Björkman, W., Beiträge zur Geschichte der Staatskanzlei im islamischen Ägypten, Hamburg 1928.

Björkman, W., Die frühesten türkisch-ägyptischen Beziehungen im 14. Jahrhundert, in 6o. doğum yılı münasebetiyle Fuad Köprülü armağanı (Mélanges Fuad Köprülü), Istanbul 1953, 57-63.

Björkman, W., Diplomatic, in $E I^{2}$ iii, 301-7.

Blair, A., Introduction, in Archival Science 10 (2010), 195-200.

Blair, S.S., Islamic calligraphy, Edinburgh 2006.

Bougard, F., Mise en écriture et production documentaire en Occident, in L'Autorité de l'écrit au Moyen Âge (Orient-Occident): XXXIX ${ }^{e}$ Congrès de la sHME SP (Le Caire, 30 avril-5 mai 2008), Paris 2009, 13-20.

Bravmann, M.M., The state archives in the early Islamic era, in Arabica 15 (1968), 87-9.

Brinner, W.M., Some Ayyūbid and Mamlūk documents from non-archival sources, in IOS II (1972), 117-43.

Broadbridge, A.F., Diplomatic conventions in the Mamluk sultanate, in AI 41 (2007), 97-118.

Broadbridge, A.F., Kingship and ideology in the Islamic and Mongol world, Cambridge 2008.

Brockelmann, C., Geschichte der arabischen Litteratur, 2 vols. + 3 vols. of supplements, Weimar and Leiden 1898-1943.

Buresi, P., Les Plaintes de l' archevêque: chronique des premiers échanges épistolaires entre Pise et le gouverneur almohade de Tunis (1182), in N. Martínez de Castilla (ed.), Documentos y manuscritos árabes del Occidente musulman medieval, Madrid 2010, 87-120.

Buresi, P., Traduttore traditore: à propos d'une correspondance entre l'Empire almohade et la cité de Pise (début XIII ${ }^{\mathrm{e}}$ siècle), in D. Aigle and P. Buresi (eds.), Les Relations diplomatiques entre le monde musulman et l'occident latin (XII ${ }^{e}-X V I^{e}$ siècle), Oriente moderno LXXXVI/1 (2008), Rome 2008, 297-309.

Buresi, P., T. Bruce, and M. Ghouirgate, Les Usages linguistiques dans les relations entre Almohades et Pisans (début du XıII ${ }^{\mathrm{e}}$ siècle), in D. Couto and St. Péquignot (eds.), Les Langues de la négociation: approches historiennes, Rennes 2017, 6376.

Camarigo, M., Ars dictaminis, ars dictandi, Turnhout 1991.

Canard, M., Le Traité de 1281 entre Michel Paléologue et le Sultan Qalāūn, in Byzantion 10 (1935), 669-8o.

Canard, M., Les Relations entre les Mérinides et les Mamelouks au XIV e siècle, in AIÉOA 5 (1941), 41-81.

Canard, M., Un traité entre Byzance et l'Égypte au Xıı I ${ }^{\mathrm{e}}$ siècle et les relations diploma- 
tiques de Michel viı Paléologue avec les Sultans Mamlûks Baibars et Qalāûn, in Mélanges Gaudefroy-Demombynes 1935-45, 197-224.

Canard, M., Une lettre du Sultan Malik Nâșir Ḥasan à Jean vi Cantacuzène (750/1349), in AIÉOA III (1937), 27-52.

Cárcel Ortí, M.M. (ed.), Vocabulaire international de la diplomatique, Valencia 1997.

Charrière, E., Négociations de la France dans le Levant, 4 vols., Paris 1848-6o.

Colin, G.S., Contribution à l'étude des relations diplomatiques entre les musulmans d' Occident et l'Égypte au XV siècle, in Mélanges Maspero, vol. III: Orient islamique, Cairo 1935, 197-206.

Darrāj, A., Les Documents arabes sur l'Égypte islamique dans les archives européennes, in Colloque international sur l'histoire du Caire/al-Nadwa al-duwaliyya li-ta'rīkh alQāhira, Cairo 27 March-5 April 1969, Cairo (1969?), 131.

Darrāj, A., Risālatān bayn sulțān Mālwa wa-l-Ashraf Qāytbāy, in Majallat Machad alMakhțūțāt al-'Arabiyya/Revue de l'Institut des Manuscrits Arabes 4 (1958), 97-123.

de Bofarull y Mascaré, P., Colección de documentos inéditos del Archivo general de la Corona de Aragón, vol. 6, Barcelona 1850.

de Capmany y de Monpalau, A., Antiguos tratados de paces y alianzas entre algunos reyes de Aragón y diferentes príncipes infieles de Asia y Africa desde el siglo XIII hasta elXV. Copiados con órden de S.M. de los originales Registros del Realy General Archivo de la Corona de Aragon, Madrid 1786.

de Capmany y de Monpalau, A., Memorias historicas sobre la marina, comercio y artes de la antigua ciudad de Barcelona, rev. edition by E. Giralt y Raventós and C. Batlle y Gallart, 2 vols. in 3, Barcelona 1961-3 (orig. pub. Madrid 1779).

Dekkiche, M., Correspondence between Mamluks and Timurids in the fifteenth century: An unpublished corpus of official letters (BnF, MS Ar. 4440), in Es XI/1-2 (2013), 131-6o.

Dekkiche, M., Crossing the line: Mamluk response to Qaramanid threat in the fifteenth century according to MS ar. 4440 (BnF, Paris), in BSOAS 8o/2 (2017), 253-81.

Dekkiche, M., Le Caire, carrefour des ambassades. Étude historique et diplomatique de la correspondance échangée entre les sultans mamlouks circassiens et les souverains timourides et turcomans (Qara Qoyunlu—Qaramanides) au XV s. d'après le ms. ar. 4440 (BnF, Paris), 2 vols., PhD dissertation, University of Liège 2011.

Dekkiche, M., New source, new debate: Re-evaluation of the Mamluk-Timurid struggle for religious supremacy in the Hijaz (Paris, BnF, MS ar. 4440), in MSR XVIII (2014), 247-71.

Dekkiche, M., The letter and its response: The exchanges between the Qara Qoyunlu and the Mamluk Sultan: Ms Arabe 4440 (BnF, Paris), in Arabica 63 (2016), 579626.

Delsalle, P., A history of archival practice, trans. and ed. M. Proctor New York 2017 (first pub. in French, Une histoire de l'archivistique, Sainte-Foy 1998). 
de Mas Latrie, L., Histoire de l'île de Chypre sous le règne des princes de la maison de Lusignan, 3 vols., Paris 1861-5.

de Mas Latrie, L., Traités de paix et de commerce et documents divers concernant les relations des Chrétiens avec les Arabes de l'Afrique septentrionale au Moyen Âge, 3 vols., Paris $1865^{-72 .}$

de Vivo, F., A. Guidi, and A. Silverstri, Archival transformations in early modern European history, in European History Quarterly 46/3 (2016), 421-34.

Dölger, F., Der Vertrag des Sultans Qalā'ūn von Ägypten mit dem Kaiser Michael VIII. Palaiologos (1281), in Dölger, Byzantinische Diplomatik, Ettal 1956, 225-44.

Dölger, F., Der Vertrag des Sultans Qalā'ūn von Ägypten mit dem Kaiser Michael viıI. Palaiologos (1281), in H.J. Kissling and A. Schmaus (eds.), Serta Monacensia: Franz Babinger zum 15. Januar 1951 asl Festgruss dargebracht, Leiden 1952, 60-79.

Dover, P.M., Deciphering the diplomatic archives of fifteenth-century Italy, in Archival Science 7 (2007), 297-316.

al-Durūbī, S.M., Aṣnāf al-tarājima fī dīwān al-inshā’ al-mamlūkī, in Majallat Majma' alLugha al-Arabiyya al-Urdunnī 27 (2003), 11-43.

al-Durūbī, S.M., Harakat al-tarjama wa-l-tárīb fī dīwān al-inshā’ al-mamlūkī (albawā'ith wa-l-lughāt wa-l-mutarjamāt), in Majallat Majma'al-Lugha al-'Arabiyya alUrdunnī 26 (2002), 11-72.

al-Durūbī, S.M., Muqaddima fì dirāsat al-tarjama wa-l-tarājima fì dīwān al-inshāò almamlūkī, Amman 2008.

Edhem, H., Mısır Fethi Mukaddematına Aid Mühim Bir Vesika, in Türk Tarih Encümeni Mecmuası XVII/19 (1928), 30-6.

El-Leithy, T., Living documents, dying archives: Towards a historical anthropology of medieval Arabic archives, in al-Qantara 32 (2011), 389-434.

El-Nashar, M.M.A., La Lettre du sultan Jakmak à la municipalité de Barcelone (Shawwāl 842/mars 1439), in L'Autorité de l'écrit au Moyen Âge (Orient-Occident): XXXIXe Congrès de la sHME SP (Le Caire, 30 avril-5 mai 2008), Paris 2009, 107-14.

El Perfume de la amistad: Correspondencia diplomática árabe en archivos españoles (siglos XIII-XVII), Madrid 2009.

Escovitz, J.H., Vocational patterns of the scribes of the Mamlūk chancery, in Arabica 23 (1976), 42-62.

Eychenne, M., Liens personnels, clientélisme et réseaux de pouvoir dans le sultanat mamelouk (milieu XIII ${ }^{e}$-fin XIV $V^{e}$ siècle), Damascus and Beirut 2013.

Fagnan, E., Catalogue général des manuscrits des bibliothèques publiques de France. Départements. Tome XVIII: Alger, Paris 1893.

Favereau, M. (ed.), Les Conventions diplomatiques dans le monde musulman: L'Umma en partage (1258-1517), in AI XLI (2007), Cairo 2007.

Filippov, I., and F. Sabaté (eds.), Identity and loss of historical memory: The destruction of archives, Bern 2017. 
Finke, H., Acta Aragonensia: Quellen zur deutschen, italienische, französischen, spanischen, zur Kirchen- und Kulturgeschichte aus der diplomatischen Korrespondenz Jaymes II. (1291-1327), 2 vols., Berlin and Leipzig 1908.

Frantz-Murphy, G., Identity and security in the Mediterranean world ca. AD640ca. 1517 , in T. Gagos and A. Hyatt (eds.), Proceedings of the 25th International Congress of Papyrology, Ann Arbor, July 29-August 4, 2007, Ann Arbor 2010, 253-64.

Friedrich, M., Die Geburt des Archivs: Eine Wissensgeschichte, Munich 2013.

Friedrich, M., Epilogue: Archives and archiving across cultures-Towards a matrix of analysis, in in A. Bausi, C. Brockmann, M. Friedrich, and S. Kienitz (eds.), Manuscripts and archives: Comparative views on record-keeping, Berlin 2018, 421-45.

Gabrieli, F., Trattato di Qalawūn [sic] coi Templari di Tortosa, in Gabrieli (ed.), Storici arabi delle Crociate, Turin 1957, 305-12, 314-21.

Gacek, A., Arabic scripts and their characteristics as seen through the eyes of Mamluk authors, in $M M E 4$ (1989), 144-9.

Gazagnadou, D., Remarques sur le problème de l'origine d'une pratique des chancelleries mamlūkes: la Țurra, in si 64 (1986), 16o-4.

Gilliland, A., Afterword: in and out of the archives, in Archival Science 10 (2010), 333-43.

Golubovich, G. Biblioteca bio-bibliografica della Terra Santa e dell'Oriente francescano, 5 vols., Florence 1906-27.

Gonzalez Maurazos, G., La documentacion diplómatica entre la Corona de Aragón y el Sultanato Mameluco durante el reinado de Jaime II: Un ejemplo de las transformaciones en las relaciones internacionales del ámbito mediterráneo en la Baja Edad Media, in Revista de Historia Medieval: Anales de la Universidad de Alicante 11 (19967), 395-403.

Grévin, B., Documents diplomatiques, diffusion des savoirs rhétoriques et problèmes d'interprétation des versions latines de correspondances réelles ou fictives avec les souverains d' Orient (XIII ${ }^{\mathrm{e}}$-début XIV ${ }^{\mathrm{e}}$ siècle), in D. Aigle and St. Péquignot (eds.), La Correspondance entre souverains, princes et cités-états: Approches croisées entre l'Orient musulman, l'Occident et Byzance (XIII ${ }^{e}$-début XVI ${ }^{e}$ siècle), Paris 2013, 51-75.

Grévin, B., Entre inš $\bar{a}^{\prime}$ et dictamen: propositions pour un comparatisme des écritures solennelles du monde musulman et du monde latin médiéval ( $\mathrm{XI}^{\mathrm{e}}-\mathrm{XV}^{\mathrm{e}} \mathrm{s}$.), in N. Martínez de Castilla (ed.), Documentos y manuscritos árabes del Occidente musulman medieval, Madrid 2010, 121-40.

Grévin, B., La Trame et la chaîne: remarques conclusives sur les rapports entre analyse textuelle et histoire diplomatique du monde musulman, in D. Aigle and P. Buresi (eds.), Les Relations diplomatiques entre le monde musulman et l'occident latin (XII ${ }_{-}$ XVI ${ }^{e}$ siècle), Oriente moderno LXXXVI/1 (2008), Rome 2008, 523-33.

Grévin, B., Rhétorique du pouvoir médiéval: les « Lettres » de Pierre de la Vigne et la formation du langage politique européen (XIII ${ }^{e}-X V^{e}$ siècle), Rome 2008.

Gully, A., The culture of letter-writing in pre-modern Islamic society, Edinburgh 2008.

\section{For use by the Author only | (C) 2019 Koninklijke Brill NV}


Guyotjeannin, O., The expansion of diplomatics as a discipline, in American Archivist 59 (Fall 1996), 414-21.

Guyotjeannin, O., J. Pycke, and B.-M. Tock, Diplomatique médiévale, Turnhout 2006. Habīb Efendi, Hatt ve-hattâtîn, Istanbul 1305[/ 1887-8].

al-Hājjī, Ḥ.N., al-'Alāqāt bayn salțanat al-Mamālīk wa-l-mamālik al-isbāniyya fì l-qarnayn al-thāmin wa-l-tāsi' al-hïrī/al-rābi' wa-l-khāmis 'ashar al-mīlādì: dirāsa wathā'iqiyya / The relations between the Mamluk sultanate and the Spanish Kindoms [sic] during the A.H. 8-9/A.D. 14-15 centuries, Kuwait 1980.

Hanaway, W.L., Secretaries, poets, and the literary language, in B. Spooner and W.L. Hanaway (eds.), Literacy in the Persianate world: Writing and the social order, Philadelphia 2012, 95-142.

Hartmann, M., Das Privileg Selims I für die Venezianer von 1517, in Orientalistische Studien. Fritz Hommel zum sechzigsten Geburtstag, Leipzig 1918, 201-22.

Hartmann, M., Die Islamisch-Fränkischen Staatsverträgen (Kapitulationen), in Zeitschrift für Politik 11 (1919), 1-64.

Head, R.C., Spaces in the archive, spaces of the archive: Material, topographical, and indexical articulations of space in early modern chancery collections, in K. Friedrich (ed.), Die Erschließung des Raumes: Konstruktion, Imagination und Darstellung von Räumen und Grenzen im Barockzeitalter, 2 vols., Wiesbaden 2014, ii, 505-19.

Hein, H.-A., Beiträge zur ayyubidischen Diplomatik, Freiburg im Brisgau 1971.

Hinds, M., and H. Sakkout, A letter from the governor of Egypt to the king of Nubia and Muqurra concerning Egyptian-Nubian relations in 141/758, in W. al-Qāḍì (ed.), Studia Arabica et Islamica: Festschrift for Ihsā̄n 'Abbās on His Sixtieth Brithday/Dirāsāt 'arabiyya wa-islāmiyya muhdāt ilā Iḥsān 'Abbās, Beirut 1981, 209-29.

Hirschler, K., Document reuse in medieval Arabic manuscripts, in COMSt Bulletin 3/1 (2017), 33-44.

Hirschler, K., From Archive to archival practices: Rethinking the preservation of Mamluk administrative documents, in JAOS 136/1 (2016), 1-28.

Holt, P.M., Al-Nāṣir Muhammad's letter to a Spanish ruler in 699/13oo, in al-Masāq 3 (1990), 23-9.

Holt, P.M., Early Mamluk diplomacy (1260-1290): Treaties of Baybars and Qalāwūn with Christian rulers, Leiden, New York and Cologne 1995.

Holt, P.M., The Mamluk sultanate and Aragon: the treaties of 689/129o and 692/1293, in Tärīh 2 (1992), 105-18.

Holt, P.M., Some observations on the 'Abbāsid caliphate of Cairo, in BSOAS 47 (1984), $501-7$.

Holt, P.M., The treaties of the early Mamluk sultans with the Frankish states, in BSOAS 43 (1980), 67-76.

Holt, P.M., Treaties between the Mamluk sultans and the Frankish authorities, in W.Voigt (ed.), XIX. Deutscher Orientalistentag, Supplement III, Wiesbaden 1977, 47484 .

\section{For use by the Author only | (C) 2019 Koninklijke Brill NV}


Horniker, A.L., Ottoman-Turkish diplomatics: A guide to the literature, in Balkan Studies 7 (1966), 135-54.

Hours, F., Fraude commerciale et politique internationale: les relations entre l'Égypte et Venise d' après une lettre de Qayt Bay (1472-1473), in BÉO 25 (1972), 173-83.

Humbert, G., Le Manuscrit arabe et ses papiers, in REMMM 99-100 (2002), 55-77.

Humbert, G., Papiers non filigranés utilisés au Proche-Orient jusqu' en 1450. Essai de typologie, in JA 286 (1998), 1-54.

Humbert, G., Un papier fabriqué vers 1350 en Égypte, in M. Zerdoun Bat-Yehouda (ed.), Le Papier au Moyen Âge: Histoire et techniques, Turnhout 1999, 61-73.

Imamuddin, S., Diwān [sic] al-inshā (Chancery in Later Medieval Egypt), (with special reference to Later Fatimid, Ayyubid and Mamluk decrees dated 528-894 H/11341489 A.c.), in Journal of the Pakistan Historical Society 28 (1980), 63-77.

Iskandar, T., Documents inédits relatifs à l'histoire d'Égypte conservés aux archives de Venise. Première série: Les Traités, 1: La Mission de Piero Diedo et la cession de Chypre, 1490 = Ta'rīkh Miṣr fı mahfüzāt al-Bunduqiyya: wathāì ghayr manshüra. Al-Silsila al-ūlā: al-mu'āhadāt. ı: Sifārat Biȳ̄rū Diȳ̃dū wa-mu'āhadāt tanāzul Miṣr 'an Qubruṣ 1490, Cairo 1956.

Iskandar, T., Les Relations commerciales et politiques de Venise avec l'Égypte aux XIV et $X V^{e}$ siècles, PhD dissertation, École des Chartes, Paris 1953.

'Izz al-Dīn, M.K. al.-D., Abū l-'Abbās al-Qalqashandī mu'arrikhan, Beirut 1990.

Jahdani, A., À propos d' un traité mamelouk de calligraphie, in F. Déroche and F. Richard (eds.), Scripts, page settings and bindings of Middle-Eastern manuscripts: Papers of the Third International Conference on Codicology and Paleography of Middle-Eastern Manuscripts (Bologna, 4-6 October, 200o), Part 2, St. Petersburg 2003, 61-4.

Juvin, C., Recherches sur la calligraphie sous les derniers Mamlouks: inscriptions monumentales et mobilières, PhD dissertation, École Pratique des Hautes-Études, Paris 2017.

Kafesoğlu, İ., Kalkaşandînin bilinmeyen bir eseri Meâsirü'l-İnâfe, in Tarih Dergisi vıı I (1956), 99-104.

Kaḥhāa,a, 'U.R., Mujam al-mu'allifin: tarājim mușannifi al-kutub al-'arabiyya, 4 vols., Beirut 1993.

Karabulut, A.R., and A.T. Karabulut, Dünya Kütüphanelerinde Mevcut İslâm Kültür Tarihi ile İlgili Eserler Ansiklopedisi [= Mu'jam ta'rīkh al-turāth al-islāmī fì maktabāt al'ālam (al-makhțūtāt wa-l-mațbū'āt) ], 6 vols., Kayseri 2006.

Keçik, M.Ş., Briefe und Urkunden aus der Kanzlei Uzun Hasans: Ein Beitrag zur Geschichte Ost-Anatoliens im 15. Jahrhundert, Hamburg 1974.

Kerslake, C.J., The correspondence between Selim I and Kāanșūh al-Ġawrī, in Prilozi za orijentalnu filologiju [Revue de philologie orientale] 30 (1980), 219-34.

Khan, G., A copy of a decree from the archives of the Fāțimid chancery in Egypt, in BSOAS (1986), 439-53. 
al-Khūlī, J., Mudākhālāt fì 'ilm al-diblūmātīk al-'arabì, Alexandria 2000.

Köhler, M.A., Alliances and treaties between Frankish and Muslim rulers in the Middle East: Cross-cultural diplomacy in the period of the crusades, trans. P.M. Holt, ed. K. Hirschler, Leiden and Boston 2013.

Korkut, B., Arapski dokumenti u državnom arhivu u Dubrovniku. Knjiga I, sveska 3: Osnivanje Dubrovačkog Konsulata u Aleksandriji, Sarajevo 1969.

Korobeinikov, D.A., Diplomatic correspondence between Byzantium and the Mamlūk sultanate in the fourteenth century, in al-Masāq 16 (2004), 53-74.

Krekić, B., Dubrovnik (Raguse) et le Levant au Moyen Âge, The Hague 1961.

Labib, S., Ein Brief des Mamluken Sultans Qā’itbey an den Dogen von Venedig aus dem Jahre 1473, in Der Islam 37 (1957), 324-29.

La Mémoire perdue: à la recherche des archives oubliées, publiques et privées, de la Rome antique, Paris 1994.

Lammens, H., Correspondances diplomatiques entre les sultans mamlouks d'Égypte et les puissances chrétiennes, in ROC 9 (1904), 151-87 and 359-92.

Lammens, H., Relations officielles entre la Cour romaine et les sultans mamlouks d'Égypte, in ROC (1903), 101-10.

Langlois, V., Le Trésor des chartes d'Arménie ou cartulaire de la chancellerie royale des Roupéniens, Venice 1863.

L'Autorité de l'écrit au Moyen Âge (Orient-Occident): XXXIX Congrès de la sHMEsP (Le Caire, 30 avril-5 mai 2008), Paris 2009.

Lazzarini, I., Écrire à l' autre: Contacts, réseaux et codes de communication entre les cours italiennes, Byzance et le monde musulman aux XIV et XV siècles, in D. Aigle and S. Péquignot (eds.), La Correspondance entre souverains, princes et cités-états: Approches croisées entre l'Orient musulman, l'Occident et Byzance (XIII ${ }^{e}-$ début XVI siècle), Turnhout 2013, 165-94.

Le Jan, R., Les Relations diplomatiques pendant le premier Moyen Âge ( $\mathrm{VI}^{\mathrm{e}}-\mathrm{XI}^{\mathrm{e}}$ siècle), in Les Relations diplomatiques au Moyen Âge: formes et enjeux. XLI Congrès de la SHME SP (Lyon, 3-6 juin 2010), Paris 2011, 13-30.

Loiseau, J., Le Silence des archives: conservation documentaire et historiographie de l'État dans le sultanat mamelouk (XIII ${ }^{\mathrm{e}}-\mathrm{XVI}^{\mathrm{e}}$ siècle), in L'Autorité de l'écrit au Moyen Âge (Orient-Occident): XXXIX $X^{e}$ Congrès de la sHMEsP (Le Caire, 30 avril-5 mai 2008), Paris 2009, 285-98.

López de Meneses, A., Los consulados catalanes de Alejandría y Damasco en el reinado de Pedro el Ceremonioso, in Estudios de la Edad Media de la Corona de Aragón VI (1953), 83-183.

López de Meneses, A., Correspondencia de Pedro el Ceremonioso con la soldania de Babilonia, in Cuadernos de Historia de España XXIX-XXX (1959), 293-337.

López de Meneses, A., Florilegio documental del reinado de Pedro IV de Aragon, in Cuadernos de Historia de España 14 (1950), 183-97. 
López de Meneses, A., Pedro el Ceremonosio y las reliquias de Santa Bárbara, in Estudios de la Edad Media de la Corona de Aragón viI (1962), 299-357.

Macler, F., Une lettre royale de sauvegarde chez les Infidèles, in Revue de l'histoire des religions 105 (1932), 85-97.

Makkī, al-Ṭ.A., Mu'āhada tijāriyya min al-qarn al-khāmis 'ashar bayna sulțān Miṣr wamalik Araghūn, in al-Majalla: Sijill al-Thaqāfa al-Rafĩa (Cairo) 45 (1960), 48-59; 49 (1961), 83-93.

Manșūr, 'A. al.-H.,, Fihris makhțūțāt al-Maktaba al-Aḥmadiyya fì Tūnis (Khizānat Jāmic al-Zaytūna), Beirut 1969 .

Marin, C.A., Storia civile e politica del commercio de' Veneziani, 8 vols., Venice 1798-1808.

Martel-Thoumian, B., Les Civils et l'administration dans l'état militaire mamlūk (IXe/XV siècle), Damascus 1991.

Martínez de Castilla, N. (ed.), Documentos y manuscritos árabes del Occidente musulman medieval, Madrid 2010.

Martinez-Gros, G., Mise en écriture et production documentaire en Orient, in L'Autorité de l'écrit au Moyen Âge (Orient-Occident): XXXIX ${ }^{e}$ Congrès de la SHMESP (Le Caire, 30 avril-5 mai 2008), Paris 2009, 21-4.

Masiá de Ros, Á., La Corona de Aragóny los estados del Norte de África: Política de Jaime II y Alfonso IV en Egipto, Ifriquía y Tremecén, Barcelona 1951.

McCrank, L.J., Documenting Reconquest and Reform: The growth of archives in the medieval Crown of Aragon, in American Archivist 56 (1993), 256-318.

Meli, P., Firenze di fronte al mondo islamico. Documenti su due ambasciate (14871489), in Annali di Storia di Firenze 4 (2009), 243-73.

Melvin-Koushki, M., The delicate art of aggression: Uzun Hasan's Fathnama to Qaytbay of 1469, in Iranian Studies 44/2 (2011), 193-214.

Mitchell, C.P., Safavid imperial tarassul and the Persian insh $\bar{a}^{\prime}$ tradition, in SIr 26 (1997), 173-209.

Mitchell, C.P., The practice of politics in Safavid Iran: Power, religion, and rhetoric, London and New York 2009.

Moeglin, J.-M., « Performative Turn », « Communication politique » et rituels au Moyen Âge: à propos de deux ouvrages récents, in Le Moyen Âge CXIII/2 (2007), 393-406.

Moeglin, J.-M. and S. Péquignot, Diplomatie et « relations internationales » au Moyen $\hat{A} g e\left(I X^{e}-X V^{e}\right.$ siècle $)$, Paris 2017.

Morelle, L., Usages et gestion de l' écrit documentaire (Occident, $\mathrm{VI}^{\mathrm{e}}-\mathrm{XII}{ }^{\mathrm{e}}$ siècle): quelques considérations sur l' acte écrit, in L'Autorité de l'écrit au Moyen Âge (OrientOccident): XXXIX ${ }^{e}$ Congrès de la SHMEsP (Le Caire, 30 avril-5 mai 2008), Paris 2009, $117-26$.

Morgan, D., Persian as a lingua franca in the Mongol Empire, in B. Spooner and W.L. Hanaway (eds.), Literacy in the Persianate world: Writing and the social order, Philadelphia 2012, 16o-7o. 
Moritz, B., Ein Firman des Sultans Selim I für die Venezianer vom Jahre 1517, in G. Weil (ed.), Festschrift Eduard Sachau zum siebzigsten Geburtstage gewidmet von Freunden und Schülern, Berlin 1915, 422-43.

Muhanna, E.I., The sultan's new clothes: Ottoman-Mamluk gift exchange in the fifteenth century, in Muqarnas 27 (2010), 189-207.

Muhanna, E.I., The world in a book: al-Nuwayri and the Islamic encyclopedic tradition, Princeton 2018.

Muhanna, E.I., Why was the fourteenth century a century of Arabic encyclopaedism?, in J. König and G. Woolf (eds.), Encyclopaedism from Antiquity to the Renaissance, Cambridge 2013, 343-56.

Müller, C., Der Kadi und seine Zeugen: Studie der mamlukischen Haram-Dokumente aus Jerusalem, Wiesbaden 2013.

Müller, C., The Haram al-Šarīf collection of Arabic legal documents in Jerusalem: A Mamlūk court archive?, in al-Qantara 32/2 (2011), 435-59.

Nājī, H., Nuṣūṣ fī l-khațț al-'arabī, in al-Mawrid 15/4 (1986), 157-270.

al-Nashshār, M.M.A., 'Alāqat mamlakatay Qashtāla wa-Arājūn bi-salțanat al-Mamālīk (1260-1341 M/658-741 H), al-Haram [Giza] 1997.

Navā̄ì, 'Abd al-Ḥusayn, Asnād va-mukātabāt-i tārīkhì-i İrān az Tīmūr tā Shāh Ismāî̀l, Tehran 1370 Sh/1991-2.

Niederkorn, J.P., R. Kauz, and G. Rota (eds.), Diplomatisches Zeremoniell in Europa und im Mittleren Osten in der frühen Neuzeit, Vienna 2009.

Nielsen, J.S., A note on the origin of the țurra in Early Mamlūk Chancery practice, in Der Islam 57 (1980), 288-92.

Ouerfelli, M., Les Traités de paix et de commerce entre Pise et l'Égypte au Moyen Âge, in L'Autorité de l'écrit au Moyen Âge (Orient-Occident): XXXIX ${ }^{e}$ Congrès de la SHMESP (Le Caire, 30 avril-5 mai 2008), Paris 2009, 45-57.

Paoli, S., Codice diplomatico del sacro militare ordine gerosolimitano oggi di Malta, raccolto da vari documenti di quell'archivio, per servire alla storia dello stesso ordine in Soria e illustrato con una serie cronologica de' gran maestri, che lo governarono in quei tempi, con alcune notizie storiche, genealogiche, geografiche, ed altre osservazioni, Lucca 1737 .

Paul, J., Archival practices in the Muslim world prior to 1500, in A. Bausi, C. Brockmann, M. Friedrich, and S. Kienitz (eds.), Manuscripts and archives: Comparative views on record-keeping, Berlin 2018, 339-6o.

Pedani, M.P., La dimora della pace: Considerazioni sulle capitolazioni tra i paesi islamici e l'Europa, Venice 1996.

Pedani Fabris, M.P., Gli ultimi accordi tra i sultani mamelucchi d'Egitto e la Repubblica di Venezia, in QSA 12 (1994), 49-64.

Péquignot, S., La Publication des documents des Archives de la Couronne d'Aragon (ca. 1840-ca. 1920), in I. Guyot-Bachy and J.-M. Moeglin (eds.), La Naissance de la 
médiévistique. Les historiens et leurs sources en Europe (XIX ${ }^{e}-$ début du XX $X^{e}$ siècle). Actes du colloque de Nancy, 8-10 novembre 2012, Geneva 2015, 243-67.

Péquignot, S., Les Diplomaties occidentales, $\mathrm{XIII}^{\mathrm{e}}-\mathrm{XV}^{\mathrm{e}}$ siècle, in Les Relations diplomatiques au Moyen Âge: formes et enjeux. XLI ${ }^{e}$ Congrès de la sHMEsP (Lyon, 3-6 juin 2010), Paris 2011, 47-66.

Péquignot, S., 'No hay nada' ou 'La Catalogne, source intarissable'? Réflexions sur une expérience de recherche entre abondance et absence d'archives, in L'Absence de texte, CHETL, 4 Paris 2011, 66-99.

Picard, C., De l'usage de l'écrit documentaire en Islam, in L'Autorité de l'écrit au Moyen Âge (Orient-Occident): XXXIX ${ }^{e}$ Congrès de la SHMEsP (Le Caire, 30 avril-5 mai 2008), Paris 2009, 127-41.

Plumley, J.M., An eighth century Arabic letter to the King of Nubia, in Journal of Egyptian Archaeology 61 (1975), 241-5.

Posner, E., Archives in medieval Islam, in American Archivist July/October (1972), 291315 .

Potthast, D., Mamlūk diplomatic letters in the context of Arabic epistolography, in F. Bauden (ed.), Culture matérielle et contacts diplomatiques entre l'Occident latin, Byzance et l'Orient islamique (XI ${ }^{e}-X V I^{e}$ siècle), Leiden and Boston, forthcoming.

Potthast, D., Translations of Arabic diplomatic letters in the Aragonese chancery, in P. Schrijver and P.-A. Mumm (eds.), Dasselbe mit anderen Worten? Sprache, Übersetzung und Sprachwissenschaft: Akten des 2. Symposiums des Zentrums historische Sprachwissenschaften (ZhS), München, 11. und 12. April 2014, Bremen 2015, 166-86.

Qurqūt, B., al-Wathāì al-'arabiyya fì Dār al-Mahfüzāt bi-Madīnat Dūbrūfnīk, Cairo 2008.

Regourd, A. (ed.), Documents et histoire, Islam, VII ${ }^{e-X V I}$ siècle. Actes des premières Journées d'étude internationales, École pratique des hautes études, IV section, musée du Louvre, département des Arts de l'Islam, Paris, 16 et 17 mai 2008, Geneva 2013.

Reinaud, J.T., Traités de commerce entre la République de Venise et les derniers sultans mameloucs d'Égypte (traduits de l'italien, et accompagnés d'éclaircissements), in JA 4 (1829), 22-51.

Reinfandt, L., Mamlūk documentary studies, in S. Conermann (ed.), Ubi sumus? Quo vademus? Mamluk studies: State of the art, Göttingen and Bonn 2013, 285-309.

Rey, F., La Protection diplomatique et consulaire dans les échelles du Levant et de Barbarie, Paris 1899 .

Reychman, J. and A. Zajączkowski, Handbook of Ottoman-Turkish diplomatics, trans. A.S. Ehrenkreutz, ed. T. Haąlasi-Kun, The Hague and Paris 1968.

Ribera, J., Manuscritos arábigos en el Archivo General de la Corona de Aragón, in Boletín de la Real Academia de la Historia 42 (1903), 278-281.

Richards, D.S., A Mamlūk Emir's 'Square' Decree, in BsoAs 54 (1991), $63^{-7}$.

Rizzo, A., Le Lys et le Lion: Diplomatie et échanges entre Florence et le sultanat mamelouk

\section{For use by the Author only | (C) 2019 Koninklijke Brill NV}


(début $X V^{e}$-début $X V I^{e}$ s.), 3 vols., PhD dissertation, University of Liège and AixMarseille Université 2017.

Rodinson, M., La Continuité du concept d' archives du monde gréco-romain au monde musulman, in J. Berque, D. Chevalier, and M. Rodinson, Les Arabes par leurs archives: $X V I^{e}-X X^{e}$ siècles, Paris 1976.

Roemer, H.R., Arabische Herrscherurkunden aus Ägypten, in $O L Z 61$ (1966), 325-44.

Roemer, H.R., Inshā', in $E I^{2}$ iii, 1241-4.

Roemer, H.R., Staatsschreiben der Timuridenzeit. Das Šaraf-nāmä des 'Abdallāh Marwārìd in kritischer Auswertung, Wiesbaden $195^{2}$.

Roncaglia, M.P., Essai bibliographique de diplomatique islamique (arabe-persaneottomane), Beirut 1979.

Rossi, F., Ambasciata straordinaria al sultano d'Egitto (1489-149o), Venice 1988.

Rubió y Lluch, A., Diplomatari de l'Orient català (1301-1409): Collecció de documents per a la història de l'expedició catalana a Orient i dels Ducats d'Atenes i Neopàtria, Barcelona 1947.

Ruiz Orsatti, R., Tratado de paz entre Alfonso v de Aragón y el sultán de Egipto, al-Malik al-Asraf Barsbay, in Al-Andalus 4 (1939), 333-89.

Silvestre de Sacy, A.-I., Extrait de la vie du sultan Almélic Almansour Kélaoun; manuscrit arabe du fonds de Saint-Germain-des-Prés, $\mathrm{n}^{\circ}$ 118bis; pour servir de suite à la notice des Manuscrits laissés par dom Berthereau, in Le Magasin encyclopédique 2 (1801), 145-61.

Silvestre de Sacy, A.-I., Lettre du Sultan Mélic-alaschraf Barsébaï, à Mirza Scharokh, fils de Timour, in Silvestre de Sacy, Chrestomathie arabe, 2 vols., Paris 1826 (repr. Osnabrück 1973), ii, 71-87 (French), 11-17 (Arabic).

Silvestre de Sacy, A.-I., Pièces diplomatiques tirées des archives de la République de Gênes, in Notices et extraits des manuscrits de la Bibliothèque du roi, et autres bibliothèques XI (1827), 1-96.

Spooner, B., and W.L. Hanaway (eds.), Literacy in the Persianate world: Writing and the social order, Philadelphia 2012.

Stern, S.M. (ed.), Documents from Islamic chanceries, Oxford 1965.

Stern, S.M., Petitions from the Mamlūk Period (Notes on the Mamlūk Documents from Sinai), in BSOAS 29 (1966), 233-76.

Stewart, D.J., Ibn Hijjah al-Ḥamawī, in J.E. Lowry and Stewart, Essays in Arabic literary biography, 1350-1850, Wiesbaden 2009, 137-47.

Storey, C.A., Persian literature: A bio-bibliographical survey. Vol. III, part 2: D. Rhetoric, riddles and chronograms, E. Ornate prose, Oxford 1990

Tafel, G.L.F., and G.M. Thomas, Urkunden zur älteren Handels- und Staatsgeschichte der Republik Venedig mit besonderer Beziehung auf Byzanz und die Levante vom neunten bis zum Ausgang des fünfzehnten Jahrhunderts, 3 vols., Vienna 1856-7.

Tanase, T., Les Mongols et le monde dans les registres de la papauté au XIII ${ }^{\mathrm{e}}$ siècle: 
l'écriture d'une histoire, in D. Aigle and S. Péquignot (eds.), La Correspondance entre souverains, princes et cités-états: Approches croisées entre l'Orient musulman, l'Occident et Byzance (XIII ${ }^{e}$-début XVI ${ }^{e}$ siècle), Turnhout 2013, 77-100.

Theunissen, H.P.A., Ottoman-Venetian diplomatics: the 'ahd-names. The historical background and the development of a category of political-commercial instruments together with an annotated edition of a corpus of relevant documents, in Electronic Journal of Oriental Studies (Utrecht) I/2 (1998), 1-698.

Thomas, G.M., and R. Predelli, Diplomatarium veneto-levantinum sive Acta et diplomata res venetas, graecas atque levantis illustrantia, 2 vols., Venice 1880-99.

Troadec, A., Une lettre de Baybars au comte Bohémond vi de Tripoli (mai 1271). Une arme dans l' arsenal idéologique des Mamelouks, in D. Aigle and S. Péquignot (eds.), La Correspondance entre souverains, princes et cités-états: Approches croisées entre l'Orient musulman, l'Occident et Byzance (XIII ${ }^{e}-$ début XVI ${ }^{e}$ siècle), Turnhout 2013, 107-25.

Tuchscherer, M., and M.P. Pedani, Alexandrie ottomane 1, Cairo 2011.

Uzun, M., Münşeat, in Türk Diyanet Vakfı İslam Ansiklopedisi xxxii, 18-20 (https:// islamansiklopedisi.org.tr/munseat).

Vaesen, J., Lettres de Louis XI, roi de France publiées d'après les originaux. Tome IX: Lettres de Louis XI, 1481-1482, Paris 1905.

Vallet, É., Des "sultans-secrétaires"? Pratique de l' archive et savoirs encyclopédiques dans l'État rasūlide (VII $-I X^{e} / X I I I^{e}-X V^{e}$ siècles), in $A I 46$ (2012), 229-54.

Vallet, É., Mūsā b. al-Ḥasan al-Mawṣilī et la correspondance des sultans rasūlides du Yémen. Genèse d'un ordre épistolaire, in D. Aigle and S. Péquignot (eds.), La Correspondance entre souverains, princes et cités-états. Approches croisées entre l'Orient musulman, l'Occident et Byzance (XIII ${ }^{e}$-début XVI ${ }^{e}$ siècle), Turnhout 2013, 127-45.

van Berchem, M., Matériaux pour un Corpus Inscriptionum Arabicarum: Égypte, Cairo 1894-1903.

Van Berkel, M., Archives and chanceries: pre-150o, in Arabic, in $E I^{3}$ (publ. online 2013), http://dx.doi.org/10.1163/1573-3912_ei3_COM_2439o.

Van Berkel, M., The attitude towards knowledge in Mamluk Egypt: Organisation and structure of the Șuḅ al-a shā by al-Qalqashandī (1355-1418), in P. Binkley (ed.), PreModern encyclopaedic texts: Proceedings of the second cOME Rs congress, Groningen, 1-4 July 1996, Leiden and New York 1997, 159-68.

Van Berkel, M., Ibn Khaldūn, a critical historian at work: The Muqaddima on secretaries and secretarial writing, in A.Vrolijk and J.P. Hogendijk (eds.), Oye Gentlemen:Arabic studies on science and literary culture in honour of Remke Kruk, Leiden and Boston 2007, 247-61.

Van Berkel, M., Opening up a world of knowledge: Mamluk encyclopaedias and their readers, in J. König and G. Woolf (eds.), Encyclopaedism from Antiquity to the Renaissance, Cambridge 2013, 357-75.

\section{For use by the Author only | (C) 2019 Koninklijke Brill NV}


Van Berkel, M., al-Qalqashandī (1355-1418), in J.E. Lowry and D.J. Stewart (eds.), Essays in Arabic literary biography, 1350-1850, Wiesbaden 2009, 331-40.

Van Berkel, M., A well-mannered man of letters or a cunning accountant: al-Qalqashandī and the historical position of the kātib, in al-Masāq 13 (2001), 87-96.

Vermeulen, U., Le Traité d' armistice entre le sultan Baybars et les Hospitaliers de Hiiṣn al-Akrād et al-Marqab (4 Ramadan 665A.H./29 mai 1267), in OLP 19 (1988), 189-95.

Vermeulen, U., Le Traité d' armistice relatif à al-Marqab conclu entre Baybars et les Hospitaliers (1 Ramadan 669/13 avril 1271), in QSA 8 (1990), 123-31.

Vermeulen, U., Timur Lang en Syrie: la correspondance entre le Mamluk Farag et le mérinide Abu Sa'id, in Vermeulen and D. De Smet (eds.), Proceedings of the 4th and 5th International Colloquium Egypt and Syria in the Fatimid, Ayyubid and Mamluk Eras II (Katholieke Universiteit Leuven, May 1995 and 1996), Leuven 1998, 303-11.

Veselý, R., Die inš $\breve{a}$-Literatur, in W. Fischer (ed.), Grundriß der Arabischen Philologie, vol. 3: Supplement, Wiesbaden 1992, 188-208.

Veselý, R., Die richterlichen Beglaubigungsmittel: Ein Beitrag zur Diplomatik arabischer Gerichtsurkunden, in Orientalia Pragensia 8 (1971), 7-23; 10 (1977), 99-122.

Veselý, R., Die richterlichen Beglaubigungsmittel: Ein Beitrag zur Diplomatik arabischer Gerichtsurkunden: 3. 'Imḍā', in U. Marzolph (ed.), Orientalistische Studien zu Sprache und Literatur. Festgabe zum 65. Geburtstag von Werner Diem, Wiesbaden 2011, 251-61.

Veselý, R., Ein Briefwechsel zwischen Ägypten und den Qaramaniden im 14. Jahrhundert, in Asian and African Studies 9 (2000), 36-44.

Veselý, R., Ein Kapitel aus dem osmanisch-mamlukischen Beziehungen. Meḥemmed Çelebi und al-Mu'ayyad Shaykh, in Armağan: Festschrift für Andreas Tietze, Prague 1994, 241-59.

Veselý, R., Eine neue Quelle zur Geschichte Ägyptens im 9./15. Jahrhundert, in C. Wunsch (ed.), in XXV. Deutscher Orientalistentag, Vorträge, München 8.-14.4.1991, Stuttgart 1994, 136-43.

Veselý, R., Eine Stilkunstschrift oder eine Urkundensammlung? Das Qahwatal-inšă des Abū Bakr Ibn Ḥidjdja al-Ḥamawī, in O. Hulec and M. Mendel (eds.), Threefold wisdom: Islam, the Arab world and Africa: Papers in honour of Ivan Hrbek, Prague 1993, 237-47.

Veselý, R., Zu den Quellen al-Qalqašandī’s Ṣubḥ al-ačšā, in Orientalia Pragensia 6 (1969), $13-24$.

Veselý, R., Zur arabischen Kanzleiliteratur, in M. Fleischhammer (ed.), Arabische Sprache und Literatur im Wandel: Kongress und Tagungsberichte der M. Luther Universität, Halle 1979, 239-44.

Veselý, R., Zwei Opera Cancellaria Minora des Šihābuddīn Aḥmad b. Faḍlullāh al'Umarī, in AO 70 (2002), 513-57.

Viladrich, M., Jaque al Sultán en el "damero maldito". Edición y traducción de un 
tratado diplomático entre los mercaderes catalanes y el sultanato mameluco (1429), in M.T. Ferrer i Mallol and D. Coulon (eds.), Actes del séminaire/seminari organitzat per la Casa de Velázquez (Madrid) i la Institució Milà i Fontanals (csic, Barcelona). L'expansió catalana a la Mediterrània a la Baixa Edat Mitjana (Barcelona, 20 April 1998), Barcelona 1999, 161-205.

Viladrich, M., Solving the "Accursed Riddle" of the diplomatic relations between Catalonia and Egypt around 1430, in al-Masāq 14 (2003), 25-31.

Vincke, J., Die Gesandtschaften der aragonischen Könige und die Reliquien der heiligen Barbara, in Historisches Jahrbuch 6o (1940), 115-23.

Vincke, J., Pedro IV de Aragón y la Tierra Santa, in Analecta sacra tarraconensia: Revista de ciències historicoeclesiàstiques 13 (1937), 79-88.

Vollers, K., Katalog der islamischen, christlich-orientalischen, jüdischen und samaritanischen Handschriften der Universitäts-Bibliothek zu Leipzig, Leipzig 1906.

Wansbrough, J., Documents for the history of commercial relations between Egypt and Venice, 1442-1512, PhD dissertation, School of Oriental and African Studies, University of London 1961.

Wansbrough, J., Lingua franca in the Mediterranean, Richmond, Surrey 1996.

Wansbrough, J., A Mamluk ambassador to Venice in 913/1507, in BSOAS XXVI (1963), 5०3-30.

Wansbrough, J., A Mamlūk commercial treaty concluded with the Republic of Florence, 894/1489, in S.M. Stern (ed.), Documents from Islamic chanceries, Oxford 1965, 39-79. Wansbrough, J., A Mamluk letter of 877/1473, in BSOAS XXIV (1961), 200-13.

Wansbrough, J., The Safe-Conduct in Muslim chancery practice, in BSOAS 34 (1971), 2035 .

Wansbrough, J., Venice and Florence in the Mamluk commercial privileges, in BSOAS XXVIII (1965), 483-523.

Wiet, G., Les Classiques du scribe égyptien au XVe siècle, in $S I$ XVIII (1963), 41-80.

Wiet, G., Les Secrétaires de la chancellerie (Kuttâb-el-Sirr) en Égypte sous les Mamlouks circassiens (784-922/1382-1517), in Mélanges René Basset. Études nord-africaines et orientales, 2 vols., Paris 1923, i, 271-314.

Yüksel Muslu, C., Attempting to understand the language of diplomacy between the Ottomans and the Mamluks, in Archivum Ottomanicum 30 (2013), 247-67.

Yüksel Muslu, C., Ottoman-Mamluk relations and the complex image of Bāyezīd II, in B. Lellouch and N. Michel (eds.), Conquête ottomane de l'Égypte (1517): Arrière-plan, impact, échos, Leiden and Boston 2013, 51-76.

Yüksel Muslu, C., The Ottomans and the Mamluks: Imperial diplomacy and warfare in the Islamic world, London and New York 2014.

Zayyāt, Ḥ., Athar unuf: nuskhat qiș̣̦a waradat ilā l-abwāb al-sharīfa al-sulțāniyya almalakiyya Īnāl min al-muslimīn al-qāținīn Lishbūna, in Al-Machriq 35 (1937), 13-22. 